Aparecida Sílvia Mellin

\title{
As Representações Sociais dos Profissionais de Saúde sobre as Finalidades e Práticas do Centro de Saúde Integração.
}


Aparecida Sílvia Mellin

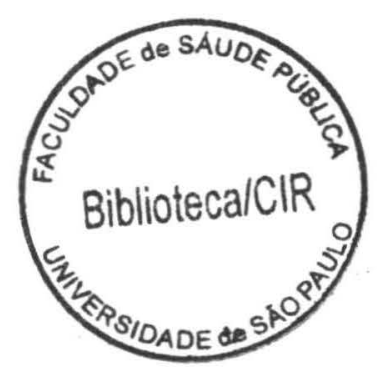

As Representações Sociais dos Profissionais de Saúde sobre as Finalidades e Práticas do Centro de Saúde Integração.

Campinas, 1998 
freata

Levanado Messaa

Em Meus momentos escuras

Can que en mim ac̃o hẩ oiluguêm.

$\mathcal{C}$ indo é aéneas e mures

Quando a vila dín ou tem.

Se um instante exgueudto a fromte

De cadte en mim sau aterrado.

Vejo o langinguo harizoute

Cheio de sal posto au uado

Pevivo existo combego

C ainda que soja ilusão

$O$ extrior am que ane esquega.

Aada mais quero mem pego.

Cutrega-lite a caragão.

Aos profisgiouais da Saúde ed Catucagãa 


\section{Agradecimentos}

Ao Professor Tanaka (Doutor Oswaldo Yoshimi), pela compreensão na mudança da trajetória por nós prevista no inicio do doutoramento, pela orientação e pelo carinho e respeito demonstrados em todo o percurso.

Aos Professores Alberto (Doutor Alberto Olavo A. Reis) e Gastão (Doutor Gastão Wagner de Souza Campos), pela grande contribuição prestada por ocasiâo da qualificação do projeto de pesquisa.

A professora Martha (Doutora Martha Rosa Pisani Destro), que leu o texto original e muito contribuiu para a compreensão do método. 
Às alunas de Iniciação Cientifica: Patrícia Saad, Luciane Torrano, Kátia Calderaro e Michele Rodrigues da Silva, que auxiliaram nas diversas etapas de construção do Estudo.

A CEAP-PUCCAMP, pelo apoio financeiro ao Projeto.

A Euclides Barboza Sandoval, pela revisão dos originais.

As professoras do Departamento de Enfermagem de Saúde Pública e Mental da Faculdade de Enfermagem da PUC Campinas, pelo companheirismo e pela riqueza de significados em nossa relação.

Às secretárias do Departamento de Saúde Materno Infantil da Faculdade de Saúde Pública da USP, pela grande solicitude e atenção a mim dispensadas.

Aos profissionais do Centro de Saúde Integração, pela disponibilidade e contribuiçâo, sem as quais este estudo não aconteceria.

Ao Miguel (Professor Doutor Miguel De La Puente), por estar solidário. 
Ao Paulo (Mellin) e Ady (Castelli Mellin) a quem devo a integridade, o sentido de família, a vocação, herdada da professora, para lecionar, o apoio material, e até mesmo a possibilidade que sempre me foi dada de ser irreverente.

A Jussara (Mellin Lutz), Adi (Mellin Ferreira) e Solimar (Mellin Campos Azevedo), pela torcida e pelas muitas crianças tão queridas.

Aos que "vivem" em minha casa, sempre tão colorida, e barulhenta, em especial à Roseli, pelo apoio nos inúmeros problemas domésticos.

Aos filhos: Tereza, que acompanhou este trabalho do começo ao fim, dedicando-se às diversas formataçöes do texto, à revisão da bibliografia, à impressão final e ao socorro com o computador, também pelo companheirismo, amizade e signifficado da nossa relação. João, do sorriso mais radiante que eu já vi, dizendo que "nós" ainda chegaremos lá e Paulo, pedindo desculpas por privá-lo, neste período, dos nossos muitos passeios a pé e de bike, e outras atenções. 
Finalmente aos músicos, principalmente os do "jazz",

que eu ouvi durante toda a escritura deste trabalho e que foram uma grande companhia. 


\section{Resumo}

Estudo de natureza interpretativa das Representações Sociais, das finalidades e das práticas do Centro de Saúde Integração, localizado no Municipio de Campinas, onde a Pontifícia Universidade Católica de Campinas, por meio de seus docentes e alunos dos cursos da área de Saúde mantêm projeto conjunto com a Secretaria da Saúde. Foi realizado em 1996, por meio de entrevistas com profissionais de Saúde dos diferentes segmentos que atuam no Serviço em questão: profissionais de nivel superior, coordenadores, docentes, médicos, enfermeiros, dentistas e profissionais de nivel médio, da equipe de odontologia e de enfermagem. Também, como forma de aprofundar o conhecimento sobre o contexto de origem das representações, realizou-se um estudo do modelo assistencial do Serviço. Como conclusões mais importantes temos que o Serviço funciona como um microssomo das diversas concepções que permeiam a Saúde Pública, e que a formação nesta área proporcionaria melhor inserção dos profissionais, com vistas à consolidação do projeto de Reforma Sanitária Nacional. 


\section{Summary}

A study of the interpretive nature, Social Representations, objectives and pratices of the Integração Health Center at Campinas where the Municipal Secretary of Health maintain a project with the Pontificia Universidade Católica de Campinas with participation of professors and students of the courses in the Health area. Was accomplished in 1996 through interviews with the professional in the following segments of the health service: superior level, coordinators, professors, doctors, nurses, dentists and middle level professionals of the dental and nursing staff. A study of the assistence model was also developed in order to give further understanding of the context of origin of the representations. The most important conclusions obtained were that the service functions as a micro universe of diverse concepts that permeat the area of the Public Health and that training in this area is the best preparaction for professionals in the service in order to consolidate the National Sanitary Reform. 


\section{Índice}

$\begin{array}{ll}\text { Apresentação } & 1\end{array}$

\section{Introdução}

I-1: A concep̧̧ão do estudo

I-2: Reflexões sobre um projeto para os Centros de Saúde 13

\section{II- Considerações sobre a Saúde Pública}

II-1: Evolução das Políticas de Saúde no Brasil

II-2: Os Centros de Saúde no Estado de São Paulo e em Campinas. História e Organização

II-3: Centro de Saúde Integração: Modelo Assistencial 
IV-Objetivos

V-Percurso Metodológico

V-1: Situação atual do problema em questão $\quad 65$

V-2: Pressupostos para Investigação $\quad 68$

V-3: Delimitação do Estudo $\quad 69$

V-4: Justificativa do uso do Método $\quad 72$

V-5: População Estudada $\quad 75$

V-6: Coleta de Dados $\quad 78$

\section{VI- Resultados}

VI-1: Trajetórias Profissionais- Primeiro Eixo 84

$\begin{array}{ll}\text { Considerações Iniciais } & 84\end{array}$

$\begin{array}{lr}\text { Profissionais de nível superior } & 85\end{array}$

$\begin{array}{ll}\text { Profissionais de nível médio } & 101\end{array}$

Comentários relativos às Trajetórias dos Profissionais 113

VI-2: O Centro de Saúde e o SUS- Segundo Eixo 118

A Finalidade do Serviço $\quad 118$ 
Profissionais de nível superior

Profissionais de nível médio

O Funcionamento do SUS

Profissionais de nível superior

Profissionais de nível médio

O Serviço de Saúde Utilizado

Profissionais de nível superior

Profissionais de nivel médio

VI-3: Aproximação das Práticas- Terceiro Eixo

As qualidades do Serviço

Profissionais de nível superior

164

Profissionais de nível médio

173

As deficiências do Serviço

176

Profissionais de nivel superior

176

Profissionais de nível médio

189

VII- Conclusões

195

VIII- Considerações sobre o trabalho desenvolvido 


\section{X-Anexos}

Anexo 1- Cursos, Departamentos e Disciplinas que participam do projeto Centro de Saúde Integração 221

Anexo 2- Carta enviada aos profissionais

Anexo 3- Roteiro de Entrevista 


\section{Apresentação}

Este trabalho é fruto da busca de maior compreensão da representação da realidade, vivenciada pelos sujeitos sociais (profissionais de Saúde) na Unidade Básica de Saúde, chamada de Centro de Saúde (CS) Integração. Serviço com o qual, como professora da Faculdade de Enfermagem da Pontifícia Universidade de Campinas, mantenho vínculo de muitos anos, o que se iniciou no chamado Ambulatório da Vila Castelo Branco da PUCCAMP, em 1980. Cabe ressaltar que, em momento anterior, realizei outro trabalho acadêmico (dissertação de mestrado), enfocando aspectos da avaliação de resolubilidade nesse $\mathrm{C} \mathrm{S}^{31}$.

A presente investigação começou a ser gestada durante a realização da dissertação já referida, quando surgiram inúmeras dúvidas e algumas certezas. Uma das certezas foi identificar alguns pontos de limitação na abordagem da avaliação sobre a qualidade dos serviços de saúde, sugerida inicialmente por Donabedian, autor clássico na área, estudado no trabalho já referido ${ }^{31}$, com enfoque nos aspectos da estrutura (Recursos físicos e materiais), do processo (Modo de trabalhar) e do

\footnotetext{
${ }^{1}$ GiMENES-MELLIN, A. S. Avaliação da Capacidade Resolutiva do CS Integração e do CS do Jardim Florence, no municipio de Campinas ${ }^{26}$.
} 
resultado (Qualidade do atendimento/Satisfação da clientela). Entre esses pontos ressalto a dificuldade em remetê-los ao contexto global em que se dá a ação; de não possibilitar a compreensão das motivações dos sujeitos com práticas nos serviços para pensar (agir) desta ou daquela forma, pois a abordagem do processo, utilizando este referencial teórico, constitui-se em uma imagem do que é feito, sugerindo ao investigador hipóteses para a ocorrência do fenômeno. Desta observação surgiu a primeira das dúvidas, relativa ao cotidiano dos profissionais e de suas vivências no CS. Como esse cotidiano é vivido (sentido, representado)? De que modo os profissionais vêem o Serviço? Qual é leitura que fazem do Sistema Único de Saúde? Assim se optou por estudar as concepções e representações dos profissionais sobre o próprio papel social e as relações entre concepção, motivação e atuação.

Postas tais considerações, as muitas dúvidas, e tendo claro que toda busca orientada pelo conhecimento do "novo" sedimenta-se no já vivenciado é que, sem negar trabalhos anteriores, busquei, na elaboração do presente estudo, outro olhar, para abrir horizontes a partir do nosso fazer cotidiano.

No caso do CS Integração interessava, para delinear o presente estudo, uma apreensão do modo de pensar dos sujeitos (profissionais de Saúde) e de sua relação com as proposições contidas no ideário da reforma sanitária e no projeto do Sistema Único de Saúde. Assim, dentre as inúmeras vias de aproximação desse objeto, houve a opção por utilizar a das Representações Sociais relativas às finalidades e práticas do Serviço. Levando em conta que toda a configuração dos serviços passa por uma determinação sóciopolítica e compreende as diversas visões de mundo subjacentes à prestação de assistência, para tanto, enquanto um construto teórico, percorri alguns caminhos expostos na seqüência. 
$\mathrm{Na}$ Introdução (I), apresento temas relativos à da concepção do estudo e reflexões acerca de um projeto para os Centros de Saúde, na seqüência (II) o contexto da Saúde Pública a partir da evolução das Políticas de Saúde no Brasil para discussão sobre a implantação dos Centros de Saúde em São Paulo e Campinas, descrevendo também o modelo assistencial do Centro de Saúde Integração. A discussão da teoria das Representações Sociais é apresentada posteriormente (III), a que seguem os Objetivos (IV), o percurso metodológico (V), a apresentação dos resultados (VI), as Conclusões (VII) e considerações acerca do trabalho desenvolvido (VIII). 


\section{I- INTRODUÇÃO}

\section{I-1- A Concepção do Estudo}

Com intuito de melhor explicitar a trajetória percorrida para a realização deste trabalho retomo alguns dos resultados obtidos na dissertação de mestrado, ${ }^{31}$ nos quais algumas características apresentaram-se de forma marcante e são semelhantes às obtidas por Tanaka ${ }^{74}$ em estudo de avaliação de resolubilidade nos Centros de Saúde do Município de São Paulo. Acrescento a elas observações pessoais decorrentes da vivência e observação cotidianas. Inclusive como forma de aumentar a capacidade de pensar o objeto deste estudo tais questões serão aqui colocadas.

A primeira delas é que o atendimento nos Serviços de Saúde tende a centrar-se na figura do médico que conta com algumas ações de apoio da equipe, não havendo maior sistematização para o trabalho dentro do $C S^{10,31}$ Desta forma, o médico atua isoladamente no interior de seu consultório no qual são estabelecidas 
relações médico-paciente. Além de ocorrer assim a atividade médica observamos que ela perdeu o critério máximo de clínica, o que pressupõe anamnese e registro em prontuário. Na ocasião, a partir da avaliação dos dados contidos nos prontuários analisados pelo trabalho anterior, ${ }^{31}$ verificamos grande descaso com o registro, o que talvez decorra da sua não utilização para um objetivo maior. Denota pouca preocupação com a leitura que "outros" farão, o que causa prejuízo à clientela e aos próprios registros de dados relativos às características da demanda. Também devemos levar em conta que o modelo denominado por Gonçalves ${ }^{32}$ de queixa conduta, segundo o qual a verbalização da queixa orienta a investigação médica e pressupõe a tomada de medidas, relacionadas unicamente a ela, pode também ser o adotado pelos profissionais com atuação nos serviços avaliados.

Além disso, apesar da vinculação dos médicos aos CS não caracterizar, necessariamente, o trabalho liberal, esse profissional, dada a autonomia da sua prática, tende a reproduzir a mesma lógica de trabalho individual na atividade em órgãos públicos, o que sucede também com os dentistas e outros trabalhadores com exercicio de caráter liberal ${ }^{8}$. Parece importante observarmos que os próprios serviços não têm outras propostas para a ação desses profissionais.

$\mathrm{Na}$ análise da autonomia do médico, mesmo quando em prática não liberal, Campos $^{8.11}$ coloca, claramente, a possibilidade do trabalho autônomo do profissional, devido ao próprio domínio do método e às características da divisão de trabalho nos serviços de Saúde.

Já os enfermeiros e auxiliares, tradicionalmente formados para obedecer a regras de conduta pouco flexiveis, o que ocorre dentro das estruturas hospitalares, extremamente normativas, com uma rígida distribuição de atividades e um esquema de trabalho em que as atividades são ininterruptas, tendem a sentir-se com maior 
"autonomia" quando realizam seu trabalho nos CS, onde as normas de conduta são mais fluidas. Apesar disso, estão propensos a reproduzir, nos serviços básicos, uma prática característica da instituição hospitalar. Segundo ela, em prejuízo à aplicação da técnica, despersonaliza-se o cliente, muitas vezes sem se compreender a mudança do objeto de trabalho na Saúde Pública. Trabalham, no mais das vezes, dando suporte à atividade médica, dedicando-se pouco às práticas especificas da enfermagem.

Tenho observado, além disso, que o trabalho dos dentistas, extremamente particular e desconhecido dos outros profissionais da Saúde, pode ser tomado como exemplo de prática liberal no serviço público, isto é, com autonomia de ação maior que a dos médicos e isolamento da equipe e do próprio serviço. Nesse sentido verifica-se, no cotidiano dos $\mathrm{CS}$, que os dentistas atuam no serviço de odontologia com prontuários próprios e lógica assistencial, também, bastante particular.

Há ainda a hipótese de que a incorporação de tecnologias à vida dos CS favoreceu a absorção de profissionais de Saúde formados dentro de uma sistemática que privilegia outro tipo de atuação, na qual há ênfase à especialização e ao caráter eminentemente técnico da atividade, sem uma vinculação política tradicional com algumas das correntes de pensamento que permeiam a Saúde Pública. Em conseqüência, não se percebe no corpo de profissionais dos serviços um propósito comum diante das propostas para atendimento às questões mais globais da assistência à Saúde da população. Também a visão de mundo difere de profissional para profissional e dos coordenadores e sanitaristas para outros profissionais.

Quando penso a relação do serviço com os usuários percebo que quem executa as ações de porta e de contato com o cliente são, geralmente, auxiliares de 
enfermagem a quem são delegadas funções de triagem e, em muitas ocasiões, de repressão da demanda, tendo em vista a capacidade de atendimento que, no mais das vezes, está aquém da procura. Essas pessoas são formadas para o trabalho de atenção à doença, não necessariamente para o trabalho em Saúde Pública. Elaboro estas críticas com base em algumas observações, como forma de, conscientes das limitações, criarmos estratégias para compartilhar ações de transformação tendo em vista os trabalhadores em exercicio no Centro de Saúde.

Também não quero incorrer no erro de pensar que a formação em Saúde Pública supra, necessariamente, todos os vieses de compreensão. Tampouco ainda pretender que os profissionais de Saúde Pública tenham um mesmo direcionamento, uma mesma cosmovisão e uma mesma proposta para o mundo (e a Saúde). Penso que a formação em/ou para a Saúde Pública pode levar a alguma compreensão do que seja o público e uma ótica um pouco ampliada com relação à Saúde, e que ela deva permear tanto a formação profissional como estar presente nos projetos de educação continuada. ${ }^{20}$

Nesse sentido, Westphal e Pelicione ${ }^{83}$ comentam que a formação dos profissionais, mesmo não universitários, tem caráter tecnicista e alia-se a uma incorporação de valores hegemônicos, ou seja, aqueles ditados mais pelo mercado e pela tecnicidade do trabalho, o que dificulta mudanças ou o "comprometimento com a causa popular". Também por isso, os profissionais em contato com a clientela realizam um trabalho que muitas vezes funciona como imposição dos limites estipulados pelos serviços a quem o utiliza. Exemplifico com as inúmeras regras e limites impostos pela instituição, tais como os horários rígidos e a obrigatória adaptação dos clientes ao que exigido pela instituição.

Difícil imaginar que, quando doentes, o serviço de saúde possa impedir o 
acesso à assistência, ou que as pessoas precisem faltar a seus compromissos por necessitar que um filho seja vacinado, por exemplo, e não saber quanto tempo será despendido na espera para esse atendimento. Como se o sofrimento fosse condição sine qua non seja possível viver.

Embora as proposições de discurso da eqüidade e do direito à saúde digam o contrário, sinto que a instituição é constituída para atender a alguma finalidade, mas que esta não está centrada em seu fim precípuo, isto é, o cliente. Como exemplo, trago a reflexão sobre o funcionamento das portas de entrada dos serviços, ou seja, as recepções que, em plena era da incorporação de tecnologia ao cotidiano, funcionam de forma obsoleta, não havendo agilidade nas buscas de dados em prontuários, o que dificulta o trabalho dos profissionais e o acesso ao serviço.

Além disso, como comentei anteriormente, a equipe auxiliar das recepçōes tende a assumir ares institucionais e regulamentares perdendo, em algumas ocasiões, a noção (será que algum dia a tivemos?) de que o usuário é cidadão. Cidadania pressupõe o exercício do Direito que se torna fato quando concretizado, o que muitas vezes não ocorre.

A critica ao modelo de assistência também é estabelecida pela clientela. Como exemplo, as mães (clientes). No caso do trabalho anterior ${ }^{31}$ conseguem, ao avaliar serviços, diferenciar o atendimento médico do dos funcionários. Os funcionários são, ao ver delas, o Serviço como um todo, do qual os médicos estão separados. Interpretando que no mau Serviço, são mal recebidas ou mal tratadas pelos auxiliares. Cabe destacar que a avaliação do CS como bom ou ruim foi feita por elas. Segundo as mães o médico, ao exercer a clínica e ser bem educado, cumpre seu papel e os funcionários, às vezes, são mal educados e exercem o poder 
de definir ou não a possibilidade de acesso. Sucupira ${ }^{73}$ verificou em estudo realizado com mães que, ao avaliarem o atendimento recebido, espontaneamente, distinguiam o médico dos outros profissionais, fenômeno por nós observado de forma recorrente, tanto nas avaliações de CS já citadas, ${ }^{31,77}$ como na pesquisa com usuários realizada em $1996 .{ }^{43}$. Ocorreu que, de maneira independente do local onde estivesse caso o médico acertasse ou não, se procedesse de forma atenciosa tal atendimento seria, em principio, bom. O que denota que, para essa clientela, as questōes administrativas do Serviço prestam-se a distanciá-la do atendimento médico, sentido como necessário.

Por outro lado, os auxiliares são identificados com a instituição. Penso que no imaginário popular, como a Prefeitura está longe e muitas vezes não passa de uma abstração, a cara do CS são seus funcionários mais presentes - auxiliares, enfermeiros e coordenadores. Uma imagem composta por vários matizes e nuanças, que depende dos humores e das circunstâncias concretas do cotidiano para apresentar-se de uma ou outra forma.

Observo ainda que o poder da instituição tende a ser assumido e exercido pelos funcionários, mesmo que de modo inconsciente, muitas vezes de forma pouco adequada, ou seja, autoritária. Embora haja uma tendência em condenar o autoritarismo no discurso, é cômodo, para a instituição ter alguém que negue o acesso ao cliente, assumindo para si, pessoalmente, as dificuldades da estrutura dos serviços, o que facilita a atuação cotidiana de prestar assistência "para cumprir tarefa". Em algum momento, portanto, nós profissionais nos apropriamos do poder, por meio do seu exercício. Para a definição do poder parto das idéias de Foucault, ${ }^{26}$ em Microfísica do Poder. Para ele, o poder é enunciado em rede, não tomado como 
fenômeno de dominação maciça e homogênea de um indivíduo sobre outro, ou de um grupo sobre outro, nem divisivel entre os que o possuem e os que a ele se submetem. O indivíduo, deste modo, não é o outro do poder e sim um dos seus principais efeitos, podendo sofrer e exercer a ação de poder.

Ainda com relação à avaliação do Serviço realizada pela clientela ${ }^{31}$ verificamos que, quando indagadas se iriam ao CS, se o caso das crianças Ihes parecesse mais grave, a maior parte das 'mães' respondeu que utilizaria outro Serviço. Elas optariam pela ida ao Pronto-Socorro, justificando que a assistência seria mais eficaz. Ficou a compreensão de que a insegurança dessas mães com o CS talvez reflita a insegurança da população que tem base tanto na realidade atual de prestação de serviços destas instituições, como na sua história pregressa. ${ }^{46,47}$ Além disso, a população brasileira tem, hoje em dia, a cultura de que o que é bem público é ruim, decorrência de um projeto de Estado que não dá prioridade à implementação das políticas sociais e, mesmo, de todo um trabalho dos meios de comunicação interessados em difundir idéias de falência dos organismos estatais de prestação de serviços. Esta cultura se reflete na concepção sobre os Postos ou Postinhos de Saúde, tradicionalmente com poucos recursos e, em decorrência, com baixa resolubilidade

Pode-se observar que, no Brasil, às classes populares costuma-se destinar os piores equipamentos sociais. Tal ocorre com a maior parte dos Serviços de Saúde. Desta forma, má qualidade não é privilégio do CS. Sabe-se também que a população, de acordo com suas concepções, escolhe o Serviço a ser utilizado. Como exemplo temos o estudo de Sucupira, ${ }^{73}$ no qual as mães selecionaram o Serviço de acordo com a hierarquia, relacionada à gravidade da queixa e a um dado modelo de assistência. É natural que as pessoas façam uma triagem dos serviços 
de acordo com as necessidades ou com o grau de resolução que imaginem existir, ou ainda com a emergência ou urgência dos casos. Embora com essa ressalva, creio que a ida a outros serviços, nos casos em questão, reflita um modelo onde os CS são de baixa resolubilidade. ${ }^{31,77}$

Diante das perspectivas de reforma sanitária e das proposições do direito à Saúde essa lógica deveria ser mudada. No cotidiano dos CS a idéia do direito, da cidadania e da eqüidade, que teoricamente permeia a prática do serviços parece constituir-se ideal. Trata-se do ideal enquanto conceito abstrato que não pode ser alcançado e implementado pelas ações rotineiras. Em termos de concretização do ideal do direito pretende-se pouco, embora atingir esse objetivo passe por uma ruptura interna e externa, tanto das pessoas, como das estruturas

Nesse sentido, com relação ao direito, Faria $^{23}$ comenta que as Declarações de Direito, enquanto instrumento de proteção legal e institucional contra as arbitrariedades do Estado; à medida que são regulamentadas pelos próprios organismos estatais podem ter sua concreção negada por eles, funcionando apenas como proposições. Desta forma, o direito constitui-se pelos fatos sociais, não funcionando apenas em decorrência de um conjunto de regras (o que tem acontecido com a própria viabilização do projeto de Reforma Sanitária (regulamentada pela lei).

Em jogo e em cena estão concepções individuais, pois indivíduos são capazes de promover transformações estruturais, se e somente se quiserem, souberem, e puderem. Já é do senso comum que ninguém nasce sabendo e que o aprendizado pode ocorrer em qualquer tempo. Para aprender precisamos resgatar nossas próprias idéias, conceitos e vontades, desvendando a realidade por meio do conhecimento das circunstâncias, da consciência da limitação e da possibilidade. 
Explicitadas as origens do presente estudo, quero deixar claro meu compromisso pessoal e profissional com a proposta de transformação social, com a Reforma Sanitária e a Saúde Pública, e o princípio segundo o qual profissionais de Saúde devam trabalhar em sintonia com os interesses e as necessidades dos cidadãos, garantindo real participação em instâncias de gerência dos serviços de saúde e da formulação das políticas de saúde. ${ }^{22}$ 


\section{I-2- Reflexões sobre um projeto para os Centros de}

\section{Saúde}

Quando da discussão do papel e do caráter dos CS é oportuno conceituar, num primeiro momento, sua finalidade que é prestar assistência integral à saúde das pessoas. A assistência integral rompe com a lógica dualista prevenção-cura, corpo-mente e revê as concepções da saúde e da doença, volta-se ao homem, passando a existir em função dele como um todo (corpo-mente) e inserido em um grupo social.

O objeto (sujeito) da atenção integral é o homem, que vive em distintas sociedades e momentos históricos bem precisos. Parece pertinente concordar com Berlinguer $^{3}$ em seus comentários sobre as formas de abordagem da saúde das pessoas. Essas proposições são bastante adequadas e, talvez pela própria simplicidade do discurso encerrem muita profundidade, constituindo-se em "linhas de ação" no entender do autor:

"O sofrimento? Reduzi-lo com tratamentos apropriados. A diversidade? Evitar que seja considerada como desvio e que produza marginalização. $O$ perigo? Distinguir o verdadeiro do falso risco, combater a doença e não o doente. 0 sinal? Aumentá-lo e interpretá-10. O estímulo? Designá-lo para o conhecimento, para a solidariedade, para a prevenção, para a transformação". (Berlinguer, ${ }^{3}$ pág.: 140)

A discussão dos Serviços de Saúde, dentro desta perspectiva, deveria ultrapassar a simples negação da incorporação de tecnologias à prestação de assistência, a suposta inutilidade, dada sua vinculação ao Capital e capacidade de veicular poder. Transcende ainda à simples racionalização da assistência e à 
normatização da demanda, como se isso fosse possivel. Além disso, se incorporamos essa visão como princípio norteador, marco conceitual das nossas práticas profissionais, resgataremos nosso quê de humanidade.

Também seria conveniente que fosse discutida e combatida a falta de credibilidade da Saúde Pública e dos Serviços Públicos, expressa tanto pela população, como pelos profissionais inseridos no Sistema. ${ }^{10,49}$ O entendimento da medicina como prática social seria o melhor subsidio para as ações dos planejadores, gerentes e profissionais da Saúde. O mesmo se dá com relação à necessidade de compromisso destes profissionais com a transformação da Sociedade, de forma a adequar a prestação de assistência, sem reduzir o coletivo ao individual, e principalmente, não reduzindo o individual ao coletivo abstrato.

Para Luz, ${ }^{41}$ a medicina é considerada uma "disciplina do social", nem tanto pelo fato de algum discurso contido em uma parcela do ideário da área considerar a determinação social da Doença, e sim pela sua própria natureza. Vemos também que essa idéia está presente em Foucault, ${ }^{26,27}$ e para melhor esclarecermos a questão, trazemos aqui um trecho extraído da autora. ${ }^{41}$

"É pelo contrário, por produzir um discurso natural sobre uma realidade social: o corpo do homem, seu sofrimento, sua morte, através da doença. Tanto mais social na medida em que o discurso naturalista sobre o corpo doente (corpo individual ou corpo social) é político em seus efeitos, contribuindo para a ordenação social e econômica de indivíduos e classes sociais na história moderna". (Pág.: 94)

No CS os profissionais de Saúde veiculam, no mais das vezes, em suas práticas, essa concepção naturalista do social. Podem, no entanto, dirigir suas ações à manutenção ou transformação da ordem, caso assumam outra forma de pensar, levando em conta a realidade, de exclusão e de Doença, propiciando que 
as pessoas tenham condições de levar uma vida melhor e com mais dignidade. A sociedade brasileira reflete injustiças sociais de várias ordens, seja pela distribuição de renda, pelo acesso ao trabalho ou à Saúde e Educação. Como a cidadania pressupõe igualdade entre as pessoas, essa figura do direito ${ }^{19}$ para nós não é fato, devendo portanto ser construída dentro de uma sociedade mais igualitária e justa. A implementação de direitos é um dos caminhos para atingir esse objetivo.

Trata-se agora de discutir qual é nossa capacidade de transformação, decorrência tanto de mudança de propósitos, como, principalmente, de açōes que denotam uma postura política, de forma consciente ou não.

$\mathrm{Offe}^{55}$ coloca que na área da Saúde e da Educação, quando o objeto (produto) não tem a concretude da produção material, o cidadão é o "órgão executivo" das políticas do Estado. Ampliam-se então as possibilidades contidas em nossas atitudes.

Enquanto prestamos assistência em serviços de saúde veiculamos necessariamente relações de saber. Os profissionais são, portanto, detentores de um conhecimento que a população não tem. ${ }^{05,44}$ Esse saber pode ser usado tanto para manutenção da ordem e do poder, como para a transformação, isto é, para a construção do conhecimento com o cliente e a população.

Tal conhecimento, como bem observa Boltanski, é definido nas escolas e, quando difundido para a população, é transmitido como o único possível. Principalmente por isso, por determos um saber que nem sempre compartilhamos, tendemos a reproduzir práticas que sofrem um isolamento institucional.

Dada a nossa vivência nos Serviços de Saúde podemos observar ainda que nem sempre, e não necessariamente, os profissionais de Saúde compreendem seu 
papel técnico e social e têm clara a própria importância, enquanto agentes de transformação da realidade.

Devemos também enfatizar que a opção por trabalhar com profissionais de Saúde transcende a questão de qualificá-los enquanto recursos humanos, o que pode ser útil em certas circunstâncias mas que, não atinge os objetivos desse trabalho. Pretendemos aqui recuperar o conceito de ação social do profissional, suas potencialidades e seu papel na transformação da realidade. Garrafa ${ }^{25}$ coloca claramente a questão ética do trabalho do profissional de Saúde e o objetivo do resgate e da ampliação da cidadania em suas práticas profissionais, o que vai além da simples implementação de medidas técnicas ou programáticas e envolve questões básicas de formação escolar e de educação em serviço

Sabemos que as escolas têm um papel de relevância na abordagem dessa questão, partindo do princípio de que todas orientam-se por um projeto político dado e nem sempre assumido claramente. No caso das escolas da área da Saúde, elas trabalham com profissionais (professores), nem sempre pedagogos e educadores e com vínculo único. No mais das vezes, esses profissionais têm um exercício liberal que se reflete nas práticas educacionais e, num dado modelo, exemplar aos alunos.

Nas instituições em que há um projeto pedagógico claro, caso da área de Saúde, com maior vinculação aos preceitos do SUS e da cidadania vemos que nem sempre a prática é implementada, pois projetos não garantem necessariamente sua concretização. Pressupomos ainda que os docentes que mais participam de sua elaboração são os que apresentam um discurso contra hegemônico, embora presente nas elaborações normativas pelas próprias características de envolvimento.

Também na educação somos obrigados a compreender o papel social do 
professor, que não se restringe à sala de aula. Assim, para Saviani ${ }^{66}$ "... Considerando-se,(...), que dado o caráter da educação como mediação no seio da prática social global, a relação em pedagogia tem na prática social o seu ponto de partida e o seu ponto de chegada...". (Pág. 86)

Sabemos que Educação e Saúde são áreas muito vinculadas, e que o profissional de Saúde tem deficiências de formação que não são apenas técnicas, mas também políticas. De que forma pode-se nos Serviços de Saúde romper com essa lógica, quanto a falhas de formação e inadequação com relação ao projeto da Reforma Sanitária?

A nosso ver, também somos educados no cotidiano do serviço, estamos nos formando profissionais, o que enseja essa provável ruptura. Notamos ainda que compartilhar idéias e discutir finalidades não tem sido a prática assumida, nem por planejadores, nem por gerentes e nem pelos próprios profissionais. Essa não discussão de princípios dificulta o envolvimento em projetos mais ampliados. Quando pensamos em ação profissional devemos refletir necessariamente num ponto que extrapola a questão, ou seja, a de que um sujeito é dono de um conhecimento. Assim, para Luckesi et al: ${ }^{39}$

"...esse conhecimento, que vimos analisando, não se processa tão individualmente... A realidade do mundo, nos circunda mediatiza as nossas consciências. Serve de núcleo e objeto de pensamento e reflexão de diversos individuos ao mesmo tempo".(Pág.: 53)

Devemos ter claro que o projeto que norteia a ação na Saúde Pública é o da Reforma Sanitária. Para ela e sua construção devem dirigir-se nossos esforços profissionais $^{8.9}$. Incorporando tais princípios podemos perceber que a reforma passa tanto pela nossa inserção, enquanto cidadãos e profissionais, como pelo 
compromisso com a transformação social. Parece cabível agora que, neste trabalho, possamos explicitar o que compreendemos por reforma sanitária.

Importante esclarecermos ser ilusório acreditar que ela aconteça via legislação e por meio de alguns intelectuais inseridos nos organismos do Estado. Além do mais, a reorganização de serviços e do sistema de saúde não configura, isoladamente, a Reforma Sanitária. Também, devemos considerar que a idéia de transformações sociais (da Saúde) não é propriedade dos técnicos de Saúde. Nasce da sociedade em busca da ampliação da cidadania, embora nem sempre a compreensão desses movimentos implique na busca por um sistema público de Saúde. Enquanto um modelo teórico podemos acompanhar a trajetória desse conceito.

Para Simione e Atique, ${ }^{68}$ os princípios da Reforma são anteriores à década de 80 , nascidos da sociedade e mantidos, durante a ditadura, por "núcleos" nos Departamentos de Medicina Preventiva. Há que se destacar, também, movimento popular; sindicatos e profissionais de saúde com esses mesmos anseios. O projeto, na visão de Campos, ${ }^{8}$ seria contra-hegemônico e de transformações radicais, diferindo a compreensão sobre o seu caráter. Embora o norte da Reforma Sanitária esteja presente nas diversas correntes de pensamento sobre a Saúde Pública no Brasil, a forma de entender os princípios e os meios para atingi-la tem sido diversa.

Por ocasião da configuração do SUS, pudemos observar a influência de alguns técnicos inseridos nas instâncias estatais e que, a nosso ver, por terem um discurso menos radical, conseguiram sobrepor seu projeto ao dos setores com propósito nitidamente socialista. Parece que trabalham com o limite da possibilidade e articulam-se mais com o Estado do que com a população em si, embora incorporem discurso de participação popular e de transformação. 
Não há a pretensão de desvalorizar um trabalho que imaginamos ter trazido ganhos legais importantes, embora vejamos o mundo de outra forma. Campos ${ }^{8}$ comenta as repercussões do trabalho deste grupo de intelectuais com muita pertinência, para ele:

"Apesar dos limites 'transformistas' desse projeto, seus defensores trouxeram inúmeras contribuições à análise e a prática institucional e se constituíram nos principais formuladores de normas legais, em larga medida incorporadas na Constituinte de 1988 e nas regulamentações posteriores." (Campos, ${ }^{8}$ pág.: 43)

Elias $^{22}$ considera que a Reforma Sanitária é a estratégia possivel para a transformação social. Parte do principio de que ela não é uma proposta "unívoca e acabada", estando em construção, não como um fim em si mesma e que essa construção depende da plena cidadania e da consolidação da sociedade democrática.

No sentido de respaldar a compreensão dos marcos conceituais que embasam essa proposta, a seguir trago ponderações relativas à abordagem da Saúde Pública no Brasil, implantação dos CS em São Paulo e em Campinas expostas, onde também se encontram descritos aspectos relativos ao modelo assistencial do Centro de Saúde Integração (local do estudo). 


\section{II - Considerações sobre a Saúde}

\section{Pública}

\section{II-1- Evolução das Políticas de Saúde no Brasil}

A assistência à Saúde das pessoas e da população tem sido assumida pelo Estado enquanto política social. Entretanto, faz-se necessário compreender as características do tipo de intervenção estatal na área da Saúde, pois ela não se dá de forma contínua, variando de acordo com as mudanças das situações políticas e históricas concretas. ${ }^{9,56}$ O Estado, enquanto responsável pela mediação dos vários interesses, intervém na prática social da medicina respondendo a princípios políticos derivados de uma opção de modelo econômico. ${ }^{21,31,78}$

Embora a relação entre Estado e medicina seja bastante antiga, observa-se seu fortalecimento com a crise econômica deste século, na década de 20 , crise esta derivada do esgotamento do modelo liberal, segundo Braga \& Paula. ${ }^{6}$ 
Em decorrência, o Estado, agora com perfil keynesiano, intervém mais concretamente na sociedade para garantir o crescimento econômico. Desta forma, por meio da representação jurídica, organiza-se para atender aos interesses do Capital. Assim, o interior da burocracia estatal passa a ter maior mobilidade na incorporação de políticas sociais, trabalhando ainda com o conceito de nivelamento dos cidadãos e o primado do direito. A idéia subjacente é a da neutralidade do Estado, que conta com o aparato jurídico para suas tomadas de decisão. ${ }^{19,23}$

Ao estudar a relação Estado/Medicina, no Brasil do Século XX, verifica-se que a intervenção estatal no setor ocorreu para beneficiar o desenvolvimento do modelo capitalista. A Saúde Pública visava o controle das inúmeras epidemias, prejudiciais às exportações e, à chegada dos imigrantes, principalmente nas cidades portuárias e nas mais importantes para o escoamento da produção do café. Cabe ressaltar que, intervenções posteriores, estão relacionadas às alterações do modelo econômico, havendo momentos marcantes dentro dessas mudanças. ${ }^{46,48}$

Com o início da industrialização no país, década de 20 , configura-se uma classe operária urbana capaz de reivindicar direitos a benefícios sociais e à assistência médica. A partir dessas reivindicações surge o embrião da previdência social e tem início a conformação de um modelo assistencial independente da Saúde Pública e de outras modalidades de assistência, reforçando-se o padrão de iniqüidade no acesso à Saúde ${ }^{6}$. De acordo com Merhy, ${ }^{46,47}$ à população em geral foram oferecidas medidas de assistência a grupos de maior risco, como mulheres e crianças, além das de controle de endemias e epidemias e, aos trabalhadores urbanos, a partir de suas contribuições financeiras, a assistência à saúde de caráter individual e curativo (Assistência Médica), como exemplo das diferentes formas de acesso 
Em uma análise mais ampliada, observa-se a conformação de vários modelos assistenciais, mais amplos que a simples separação Saúde Pública e Medicina Previdenciária. Segundo Merhy, ${ }^{46}$ os diferentes serviços de saúde foram oferecidos a distintos grupos sociais e definidos a partir de seu engajamento na força de trabalho.

Dentre os diversos modelos que coexistiram, cabe destacar o de prestação liberal de serviços, comprados por uma pequena parcela da população; o modelo previdenciário que contou com intervenção estatal mais enfática a partir da década de 30 , destinado aos trabalhadores registrados formalmente, ao qual posteriormente agregaram-se os serviços de Medicina de Grupo, além da Saúde Pública, destinada a um grande contingente de pessoas com inserção informal ou não inseridas no mercado de trabalho, e assumido inteiramente pelo Estado.

Para Paim ${ }^{57}$.

"Modelos Assistenciais são combinações tecnológicas uitlizadas pela organização dos serviços de saúde em determinados espaços-populações, incluindo ações sobre o ambiente, grupos populacionais, equipamentos comunitários e usuários de diferentes unidades prestadoras de serviços de saúde com distinta complexidade (postos, centros de saúde, hospitais, etc.)". (Pág.: 147)

Quanto aos recursos utilizados na assistência à Saúde, o Estado, mesmo quando prestador de serviços, preocupou-se mais em atender aos interesses da medicina liberal/privada, tornando-se tutor e mantenedor. Optou por comprar serviços, ao invés de garantir uma estrutura própria de prestação de assistência. Assim se preservou o lucro das empresas médicas. 6,46

A partir de 1964, a lógica do desenvolvimento capitalista incorpora-se mais acentuadamente à Medicina como conseqüência do modelo de desenvolvimento adotado pela ditadura militar. Na ocasião, ocorre a chamada capitalização privada 
da medicina, quando alguns grupos investem no oferecimento de serviços a serem comprados pelo Estado. ${ }^{46}$ Neste periodo, enquanto se expande o setor de assistência à Saúde e o bolo da economia cresce, diminuem os investimentos estatais na Saúde Pública com conseqüente reflexo no perfil de morbidade e mortalidade da população, o que ampliou a baixa qualidade de vida causada pela má distribuição das riquezas. ${ }^{6}$ Essa situação de pobreza e desigualdade gera um aumento na demanda por ações de saúde. Além disso cresce o número de trabalhadores engajados na previdência e que também consomem seus serviços. Esses fatores, aliados a um modelo assistencial curativista e às fraudes dos vendedores de serviços de saúde, corroboradas pela burocracia estatal, provocam uma crise na previdência e no próprio setor Saúde. O modelo econômico proposto pela ditadura começou a esgotar-se na década de 70 , quando ocorre a chamada distensão democrática, o que permitiu maior liberdade de expressão. Na ocasião, organizam-se alguns setores da sociedade civil, comprometidos com as liberdades democráticas e a melhora da qualidade de vida, obrigando o Estado a promover melhores condições de vida e de saúde. O governo, por sua vez, vê-se às voltas com tais pressões, que se somam à crise econômica e a do setor Saúde, evidenciadas no discurso oficial, já em 1976. Essas crises e as pressões populares determinam que se procure formular propostas alternativas de transformação para o sistema de saúde.

Transformações começam a ser configuradas na década de 80 , quando ocorrem: a VII Conferência Nacional de Saúde, ${ }^{57,77}$ inspirada em Alma Ata; o Plano do CONASP (Conselho Consultivo da Previdência e Assistência Social); as AIS (Ações Integradas de Saúde) e a VIII Conferência Nacional de Saúde $(1986)^{14}$, que 
propõe diretrizes para a Reforma Sanitária Nacional. Diretrizes discutidas durante a elaboração da Constituição de 1988 servem de base a algumas propostas. ${ }^{31}$ A carta constitucional, no conjunto, resultou em conquistas básicas para a população, fruto da presença dos movimentos sociais organizados e articulados com constituintes progressistas. Cabe ressaltar, neste momento, um grupo de intelectuais que compõe o movimento sanitário, preocupados com as formulações legais como meio de alcançar a reforma sanitária. Como exemplo temos as palavras de Teixeira Fleury, ${ }^{79}$ para quem:

".. o conceito de Reforma Sanitária refere-se a um processo de transformação da norma legal e do aparelho institucional que regulamenta e se responsabiliza pela proteção à saúde dos cidadãos e corresponde a um efetivo deslocamento do poder político em direção às camadas populares ...". (Pág.: 39)

Uma análise da evolução das políticas de saúde no periodo posterior ao da elaboração constitucional e os inúmeros imprevistos, demonstram a fragilidade da concepção de que transformações sociais dão-se apenas a partir do arcabouço jurídico institucional, em que pese importância em várias situações.

Retomando os ganhos obtidos na Constituição, com relação à Saúde, pela primeira vez na história das constituições brasileiras é assegurado o direito à Saúde. Também na Constituição estão as diretrizes para a constituição do Sistema Único de Saúde (SUS), a serem posteriormente regulamentadas em lei. ${ }^{40}$

O direito à Saúde é um direito social. Donângelo ${ }^{21}$ analisa que a conquista e a ampliação dos direitos sociais dá-se a partir do maior poder de barganha com o Estado, por parte dos mais afetados pela desigualdade social. Embora tenha havido esse avanço na Constituição, a legislação regulamentadora do SUS sofreu 
inúmeros vetos do governo federal, que descaracterizaram a proposta original, impondo inúmeras dificuldades para a sua efetivação. ${ }^{45}$ Esses vetos respaldam as concepções de Faria, ${ }^{23}$ para quem os conceitos idealistas presentes nas teorias dos direitos naturais fazem com que se adquira a ilusão da compreensão e superação de tensões e antagonismos pelas soluções jurídicas, o que não é necessariamente verdadeiro. Talvez, no presente, estejamos sofrendo as conseqüências da crença de que, a partir da lei, a reforma seria conquistada. No momento, o SUS convive com o sistema liberal privado de prestação de assistência. Além disso, não há repasse automático de recursos aos municipios (exceto para alguns), havendo sobrecarga de gastos com saúde. ${ }^{74,75}$

É fácil sentir que a concretude da Reforma Sanitária está longe de ser alcançada. Podemos ainda compreender melhor que reformas passam necessariamente por uma transformação social e mudanças mais ampliadas da sociedade como um todo. No Brasil, certamente não ocorreram transformações sociais que propiciem uma reforma no setor Saúde. Ademais, vemos o discurso contido no ideário da reforma sanitária sendo incorporado de várias maneiras e relido de formas diversas pelos sujeitos sociais responsáveis pela formulação e veiculação das políticas de Saúde.

É possível observar a persistência de uma estratificação na prestação de assistência. Dentro desse contexto tem cabido ao SUS, principalmente, a prestação de atendimento básico e hospitalar, destinado a uma população de baixa renda, sem poder de consumir Saúde. Merhy ${ }^{45}$ considera que essa população sejam os "cidadãos mínimos" a quem o Estado oferece serviços de qualidade questionável, na maioria das vezes, com ações de reparação de condições também mínimas. 
No interior dessa estrutura mais ampla nasceram os CS que são, atualmente, uma das expressões finais das Políticas Públicas de Saúde e que têm uma finalidade social a cumprir, ou seja, a de prestar assistência integral às populações a eles adstritas. Nesses espaços encontram-se os diversos profissionais de Saúde, sujeitos de uma prática social. Parece cabivel, no momento, trazer algumas reflexões sobre as características históricas da implementação desses serviços no Estado de São Paulo e em Campinas. 


\section{II-2- Os Centros de Saúde no Estado de São Paulo e}

\section{em Campinas. História e Organização}

Para melhor compreender as características de criação e organização dos CS no Estado de São Paulo e em Campinas, retomamos alguns dados históricos.

Os Centros de Saúde foram implantados no Estado de São Paulo por Geraldo Paula Souza, obedecendo à lógica intitulada por Merhy ${ }^{48}$ de Modelo Médico Sanitário. Essas instituições deveriam executar ações de controle de endemias, educativas, de prevenção e preservação da saúde. Embora houvesse essa proposta inicial e a fundação na década de 20 do Centro de Saúde Modelo, em São Paulo, Capital, até 1967 a maioria dos serviços funcionou com estrutura verticalizada de dispensários.

A proposta de atuação dos Centros de Saúde estaduais, após a unificação dos dispensários em 1967, incorporava a linha de execução de ações programáticas destinadas em particular à gestante, à criança, à tuberculose e à hanseniase, não havendo espaço para atenção à saúde de pessoas doentes. Esse tipo de atuação do governo estadual manteve-se de forma semelhante até 0 início da década de 80 , quando sofreu grandes alterações, decorrentes das mudanças nacionais e sua conseqüente repercussão no Estado. Tais transformações tiveram, em um primeiro momento, cunho eminentemente racionalizador, incorporando a integração dos diversos Serviços Públicos de Saúde. Ao mesmo tempo, proporcionaram melhora na estrutura da Rede Pública de Serviços com maior 
ênfase para os Serviços Básicos (CS) que tendem, no periodo, a rever modelos assistenciais e a tornar-se uma hipotética porta de entrada para o Sistema. ${ }^{76}$ Essas mudanças estruturais foram possiveis pelo repasse de verbas do Ministério da Previdência e Assistência Social para o Ministério da Saúde e, deste, para as Secretarias Estaduais de Saúde. ${ }^{74}$

Como um dos pressupostos para as alterações do modelo fosse a descentralização administrativa, nessa ocasião, os municípios passaram a, gradativamente, oferecer serviços de saúde. Cabe ressaltar que até a implementação das AIS, em 1984, os municípios do Estado não prestavam assistência à saúde, limitando-se ao fornecimento de ambulância e concessão de medicamentos.

Em Campinas ocorre uma experiência diversa e, já no início da década de 70 são criados os primeiros Postos de Saúde Municipais. ${ }^{37}$ Para Smeke, ${ }^{69}$ esses serviços têm origem nas transformações do município, ocorridas na década de 70 , quando houve aumento na industrialização e no fluxo migratório, juntamente com o crescimento da população favelada na periferia da cidade. No período, junto com a piora dos indicadores de saúde da população, havia insuficiência de equipamentos sociais e de assistência. Ao mesmo tempo, existia um quadro nacional de articulação de movimentos populares e de alguns setores da classe trabalhadora. Esse movimento também faz-se presente em Campinas, e traz reflexos na configuração da assistência à Saúde da população. Assim, os Postos de Saúde em Campinas têm suas raízes no movimento popular, principalmente nas comunidades eclesiais de base e em um seguimento de técnicos de saúde articulados em movimento encampado pelo Departamento de Medicina Preventiva da UNICAMP, 
por meio do Laboratório de Educação Médica para a comunidade (LEMC). ${ }^{69} \mathrm{~A}$ conformação dos serviços tem caráter basicamente político o que sobressai neste trecho extraído do trabalho de Smeke:

"Por conseguinte, se por um lado, a preocupação era com o processo de conscientização política da população, por outro, e como decorrência, passava a

ser, como efeito a criação de um modelo de atenção à saúde efetivamente articulado aos interesses dos "explorados", que tivesse o caráter de embrião de uma política de saúde e organização do cuidado médico para a nova sociedade que se descortinava num futuro próximo". (Pág.: 294)

É interessante destacar que, já em 1969, a Prefeitura Municipal construiu o Pronto Socorro Municipal e cinco Unidades Sanitárias, denotando preocupação com a implementação de políticas sociais, embora sem obediência a critérios epidemiológicos para implantação destes serviços.

L'abatte ${ }^{37}$ ao fazer uma retrospectiva histórica da questão da Saúde no município, comenta que, no final da década de 70 a Secretaria de Saúde, dirigida pelo Dr. Sebastião de Moraes, inicia a ampliação da rede de serviços básicos, adotando o modelo de "Medicina Comunitária e Participação Popular".

De acordo com Smeke, ${ }^{69}$ a partir de 1977 conforma-se uma rede municipal de serviços, o que ocorre também em municípios como Londrina (PR) e Montes Claros (MG).

Em 1982, a própria Secretaria inicia um projeto de integração de seus serviços com os dois Hospitais Universitários (UNICAMP e PUCCAMP) e com os serviços estaduais, preocupada com a racionalização da assistência e com a implementação de uma rede hierarquizada de atenção. Este projeto é então denominado Pró Assistência I.

L'abatte $^{37}$ descreve o processo da seguinte maneira: 
"Neste contexto, um grupo de técnicos de algumas instituições do setor público de saúde de Campinas, basicamente das secretarias estadual e municipal de saúde e das Universidades, partindo de um diagnóstico sobre a situação do nível de saúde da população de Campinas e das várias atividades desenvolvidas pelas instituições ligadas ao setor público de saúde, bem como relacionadas à prestação de cuidados à saúde realizados pelas duas Universidades, elabora a proposta do Pró Assistência I, através da qual se propõe iniciar um processo de integração dos vários serviços". (Pág.: 275)

$\mathrm{Na}$ ocasião detectou-se que a rede básica, com quarenta e oito unidades (trinta e seis municipais, oito estaduais e quatro da PUC, não funcionava como porta de entrada do sistema, por atender apenas a vinte por cento da população, e que ela necessitava mudanças para tornar-se mais efetiva. ${ }^{37}$

Paralelamente ocorre, nacionalmente, o projeto Ações Integradas de Saúde, com adesão imediata do "Pró Assistência". Campinas foi o primeiro municipio a assinar o convênio AIS, em 1982, com o nome Programa Pró-Assistência. O convênio foi firmado em 1984 já com o nome de AlS. No ano de 1987 a prefeitura municipal assina o convênio SUDS (Sistema Unificado e Descentralizado de Saúde), com vistas à municipalização. ${ }^{37}$

A gestão da Secretaria de Saúde iniciada em 1989 propõe, na ocasião, de acordo com Campos, ${ }^{11}$ adotar como prioridade a reforma do modelo de prestação de Serviços de Saúde a ser atingida tanto por meio da expansão da rede de serviços como pela: "... reformulação das práticas da administração e do modelo". (Pág.: 144) Para tanto, são criadas as Diretorias Regionais de Saúde com equipes multidisciplinares, forma de consolidar planos locais. Instâncias colegiadas de gestão tais como o Colegiado de Governo, Coordenadores e Assembléia dos Trabalhadores da Saúde, cujas reflexões eram levadas ao Conselho Municipal de Saúde. Houve também estímulo à formação dos Conselhos Locais de Saúde (ainda não regulamentados por lei). 
A rede de CS, então expandida e com mais recursos humanos, deveria funcionar como porta de entrada do sistema, com capacidade de realizar ações de demanda espontânea, em atendimento ao modelo de atenção integral à saúde.

Cabe destacar um grande movimento para qualificação da rede que envolveu desde o reforço ao papel de Coordenador dos Serviços, até medidas de gerenciamento dos serviços, como Planejamento anual e a criação das planilhas de avaliação de desempenho das Unidades Básicas de Saúde, além da contratação de um grande contingente de profissionais, via concursos públicos.

Destaca-se como medida bastante progressista, tomada na ocasião, o processo de seleção dos coordenadores, por meio de prova de títulos e que foi deixado de lado nas gestões posteriores para as quais esses cargos assumiram o caráter de confiança.

Atualmente, o municipio encontra-se com mecanismos de gestão semiplena dos recursos para assistência à Saúde, encaminhando-se para a gestão plena. 


\section{II-3- Centro de Saúde Integração: Modelo}

\section{Assistencial.}

\section{Considerações Iniciais}

A vivência desta autora no Serviço, diretamente vinculada aos estágios de alunos do quarto ano de enfermagem, dentro da disciplina Enfermagem em Saúde Pública, com enfoque no Planejamento em Saúde fez com que houvesse a priori dados sobre o funcionamento do CS. Foi possivel ainda, tomar por base o Prontuário Gerencial da Unidade, ${ }^{25}$ que é um instrumento auxiliar da gerência do Serviço, relativo ao ano de 1996 e elaborado pela Coordenação Administrativa do $\mathrm{CS}^{\star 23}$. Ai temos os indicadores de mortalidade por causa e faixa etária, produção e produtividade do Serviço nas diversas áreas. Pudemos também analisar documentos elaborados para o Projeto Docente da Universidade, a dissertação de mestrado de Martins ${ }^{42}$ (Maria Teresa Cristina), e a tese de doutorado de Garcia ${ }^{28}$ (Maria Alice), professoras da PUC CAMPINAS, e que estudaram as questões da interdisciplinaridade para os docentes com atuação no CS Integração e das trajetórias dos docentes do Departamento de Medicina Social e Preventiva da Faculdade de Ciências Médicas, respectivamente. Também foram utilizadas informações contidas na pesquisa elaborada por Martins e Mellin ${ }^{43}$, em 1996, e 
relativa à análise da demanda e avaliação dos usuários sobre o Serviço.

\section{Localização e História}

O Centro de Saúde Integração localiza-se na região sudoeste do município de Campinas, Vila Castelo Branco, Rua Zoca, $n^{\circ}$ 161. Prédio próprio (construido pela Prefeitura Municipal), com $402 \mathrm{~m}^{2}$, tem como área de abrangência a Vila Castelo Branco, Condomínio Raul Renato, Jardim Garcia, Vila Padre Manoel da Nóbrega, Parque dos Eucaliptos, Jardim Londres e parte do Jardim Paulicéia. No Serviço atua em parceria com a Pontifícia Universidade Católica de Campinas.

A Universidade integrou-se a esse Centro de Saúde também como consequêencia da evolução do seu projeto pedagógico. Em decorrência participa de outros serviços de saúde na região do Eixo John Boyd.

O Projeto Pedagógico objetivou, prioritariamente, adequar a formação do aluno aos pressupostos da abertura da Universidade para a sociedade, dentro de um contexto de compromisso com as transformações sociais. ${ }^{28}$

No início da década de 80, a PUCCAMP definiu seus compromissos para com a sociedade, o que trouxe reflexos claros para os cursos da área de saúde. Dentro desse contexto, a Faculdade de Ciências Médicas, por meio de seu Departamento de Medicina Social e Preventiva, optou por criar quatro Centros de Saúde sendo o primeiro deles na Vila Castelo Branco onde anteriormente havia um

FIALHO, R. B. Prontuário Gerencial do Centro de Saúde Integração. Campinas, 1996. (mimeo) ${ }^{3}$ 
ambulatório da Universidade. De acordo com Martins, ${ }^{43}$ que sistematizou dados relativos à nossa história:

"... a concretização dos Centros de Saúde da Universidade deveu-se a um projeto pioneiro de profissionais inseridos no Departamento de Medicina Social e Preventiva da PUCCAMP, que iniciou sob coordenação do Dr. Miguel Tobar Acosta em 1980 em um ambulatório já existente na Vila Castelo Branco. De imediato, docentes do Departamento de Enfermagem de Saúde Pública juntarem-se ao projeto; a adesão dos outros cursos deu-se de modo gradativo": (Pág.:131)

O CS da Vila Castelo Branco funcionou de forma isolada até 1990. $\mathrm{Na}$ ocasião da inauguração do CS Integração, no mesmo bairro, a equipe da PUCCAMP entabulou discussões sobre a pertinência de integrar-se ao novo Serviço, o que ocorreu em 1991, como forma de juntar esforços para a execução de um trabalho comum.

Com relação aos cursos da área de Saúde, temos claro que sua adesão aos trabalhos nos CS ocorreu dentro da perspectiva de atender aos pressupostos do projeto pedagógico que enfatizava o compromisso social da universidade. Para estes cursos, significava a adoção de um modelo de ensino diferente do denominado hospitalocêntrico. O projeto pedagógico mais amplo determinou transformações em todos os cursos, para que se pudesse atuar na Saúde Pública. Alguns aderiram mais tarde, como por exemplo fonoaudiologia. Outros ainda não se integraram a ele, caso de odontologia e serviço social. Participam atualmente do Serviço as seguintes unidades: Faculdade de Ciências Médicas - Curso de Ciências Farmacêuticas, Fisioterapia, Medicina, Nutrição e Terapia Ocupacional - Faculdade de Enfermagem - Instituto de Psicologia - Curso de Fonoaudiologia e de Psicologia. Dados referentes à distribuição das Disciplinas e atuação no serviço encontram-se em anexo (anexo 1). 
Esse projeto ainda está em elaboração e sofre com as constantes crises sofridas pela educação e a saúde no país. A propósito do Centro de Saúde Integração, no momento há tentativa de firmar convênio com a Secretaria Municipal de Saúde para que se estabeleçam as bases contratuais entre a Universidade e o Serviço. Cabe ressaltar que, na ocasião da escritura deste estudo há uma discussão, que envolve a Universidade e a Secretaria Municipal de Saúde, para elaboração definitiva do projeto de parceria para a Rede Básica.

\section{Características do CS e Indicadores de Saúde da População}

Na área de abrangência do Serviço residiam cerca de 36.000 habitantes, em 1996. O CS integra o Eixo da "Dunlop", sob gerência do Distrito de Saúde Noroeste. Dada a estrutura física e os recursos médicos existentes sabemos, a priori que, utilizando parâmetros definidos pelo SUDS-SP, ${ }^{74}$ ele não é capaz de atender às necessidades de saúde da população da área.

Foi inaugurado em 1989, e resulta da integração do CS da Vila Pe. Manuel da Nóbrega ao CS do Jardim Garcia. Em 1991 juntou-se a ele o CS da Vila Castelo Branco da PUC. A Universidade mantém alugado o prédio onde funcionava este serviço, por falta de espaço físico no CS Integração. No local há atendimento de fisioterapia, fonoaudiologia, psicologia, atendimento médico a idosos, terapia ocupacional e coleta de exames laboratoriais do Centro de Saúde.

Funciona de segunda a sexta-feira no horário das 7 às 21 horas, três turnos. O espaço interno é dividido em uma recepção, 3 ambientes com cadeiras para espera, 2 consultórios destinados ao uso em pediatria, 2 em ginecologia, 4 em 
clínica médica. Dado o grande número de alunos e docentes, estas salas são bastante disputadas, o que obriga os coordenadores a fixarem uma escala de uso na porta de cada uma. Assim, os profissionais alocam-se conforme as disponibilidades, causando muitos transtornos, principalmente pela manhã e tarde. Deste modo, um dos consultórios de clínica transformou-se em sala de atendimento de psicologia ou, em periodos vagos, de nutrição; o outro é destinado ao atendimento psiquiátrico. Há ainda os para atendimento de enfermagem a adultos e realização de eletrocardiograma. Outro consultório é utilizado pela enfermagem para atender crianças e, quando desocupado, adultos. O Serviço possui: uma sala pequena de administração, sala de vacinas (medicação parenteral), curativos e outra de inalação ( 3 saídas); um espaço improvisado para farmácia que, ao término deste estudo, foi transferida para a sala de reuniões, por motivo de segurança e controle dos medicamentos; uma para esterilização (com expurgo anexo), e cinco banheiros. $O$ atendimento odontológico é feito em uma sala própria bem ampla, com dois equipos e pia para escovação supervisionada. Funciona como referência em ginecologia para outros da área, por contar com colposcópio e maiores recursos tecnológicos, e também para saúde mental. No Serviço são desenvolvidas ações de vigilância à saúde e assistenciais, voltadas para individuos e grupos. Tais ações têm caráter eventual ou programado. A coordenação é exercida por um funcionário da Prefeitura Municipal e por um coordenador acadêmico (professor da PUC). Tem por hábito divulgar dados de produção e atividades realizadas pelo CS para os usuários e equipe, dados esses afixados na sala de recepção do Serviço. Há um Conselho Local de Saúde com reuniões realizadas mensalmente, cujos membros são coordenadores, representantes dos funcionários e dos usuários. Os dados de 
estrutura etária e alguns indicadores de saúde e de avaliação do Serviço encontram-se expostos a seguir.

Figura 1 - População da área de cobertura, segundo faixa etária e sexo, Centro de Saúde Integração, 1996.

\begin{tabular}{|c|c||c|c|}
\hline $\begin{array}{c}\text { FAIXA } \\
\text { ETÁRIA }\end{array}$ & HOMENS & MULHERES & TOTAL \\
\hline 0 a 4 & 1457 & 1511 & 2968 \\
\hline 5 a 9 & 1631 & 1672 & 3303 \\
\hline 10 a 14 & 1635 & 1573 & 3208 \\
\hline 15 a 19 & 1624 & 1664 & 3288 \\
\hline 20 a 24 & 1580 & 1774 & 3354 \\
\hline 25 a 29 & 1755 & 1886 & 3641 \\
\hline 30 a 34 & 1566 & 1628 & 3194 \\
\hline 35 a 39 & 1252 & 1457 & 2709 \\
\hline 40 a 44 & 1132 & 1453 & 2585 \\
\hline 45 a 49 & 1038 & 1056 & 2094 \\
\hline 50 a 54 & 804 & 987 & 1791 \\
\hline 55 a 59 & 670 & 772 & 1442 \\
\hline 60 a 64 & 506 & 619 & 1125 \\
\hline 65 a 69 & 335 & 408 & 743 \\
\hline 70 a 74 & 155 & 288 & 443 \\
\hline 75 a 79 & 116 & 197 & 313 \\
\hline 80 a + & 76 & 142 & 218 \\
\hline & 17.332 & 19.088 & 36.420 \\
\hline
\end{tabular}

Fonte: Prontuário Gerencial

A população da área de abrangência do Serviço (Figura 1), é formada por um grande contigente de indivíduos maiores de 15 anos (74\%), e mesmo de idosos (maiores de 65 anos - 4,7\%). Também pode-se observar maior proporção de mulheres nas faixas etárias mais avançadas o que é reflexo do perfil de mortalidade masculina. Essa população adulta e idosa utiliza bastante o CS cujo quadro de 
médicos clínicos não atende às necessidades de Saúde da população, o que se agrava ao considerarmos a demanda por ações programadas, principalmente no caso dos hipertensos, diabéticos e idosos.

Figura 2- Proporção de óbitos, segundo Grupo de Causa (OMS), moradores da área de cobertura do CS Integração, 1996.

\begin{tabular}{|c|c|c|}
\hline Grupo de Causa & 1994 & $\%$ de óbitos \\
\hline Grupo VII & $\begin{array}{c}\text { Aparelho } \\
\text { circulatório }\end{array}$ & 35,5 \\
\hline Grupo VIII & $\begin{array}{l}\text { Aparelho } \\
\text { respiratório }\end{array}$ & 15,8 \\
\hline $\begin{array}{c}\text { Grupo XVII } \\
\text { Grupo II } \\
\end{array}$ & $\begin{array}{c}\text { Causas Externas } \\
\text { Neoplasias }\end{array}$ & $\begin{array}{l}11,6 \\
10,7\end{array}$ \\
\hline \multicolumn{3}{|c|}{1995} \\
\hline Grupo VII & $\begin{array}{c}\text { Aparelho } \\
\text { circulatório }\end{array}$ & 39,8 \\
\hline Grupo VIII & $\begin{array}{l}\text { Aparelho } \\
\text { respiratório }\end{array}$ & 13,7 \\
\hline Grupo II & Neoplasias & 10,6 \\
\hline Grupo XVII & Causas Externas & 9,6 \\
\hline \multicolumn{3}{|c|}{1996} \\
\hline Grupo VI & $\begin{array}{c}\text { Aparelho } \\
\text { circulatório }\end{array}$ & 34,7 \\
\hline Grupo II. & Neoplasias & 16,2 \\
\hline Grupo VIII & $\begin{array}{l}\text { Aparelho } \\
\text { respiratório }\end{array}$ & 15,6 \\
\hline Grupo IX & Aparelho digestivo & 7,8 \\
\hline
\end{tabular}

Dadas as características da estrutura etária da população da área de cobertura do CS e a própria inserção social dessas pessoas, podemos observar um perfil de mortalidade de transição, no qual predominam as doenças crônicas e degenerativas acompanhadas de alta mortalidade por causas externas, principalmente decorrentes da violência urbana (Figura 2). Além disso é importante destacar que o padrão de mortalidade altera-se de maneira expressiva nos anos 
analisados havendo tendência ao aumento da proporção de óbitos por Neoplasias.

Com relação à Mortalidade Proporcional (Figura 3), observa-se como fenômeno de maior relevância a alta mortalidade dos adultos jovens (20 a 49 anos $22 \%$ ), que se reflete na curva de Nelson de Moraes, a despeito do indicador de Swaroop Uemura (mortalidade de maiores de 50 anos) aproximar-se do de países desenvolvidos (Figura 4).

Os dados descritos são característicos de população com perfil de mortalidade bastante peculiar que, por suas características, necessita de tecnologia apropriada e maiores dispêndios em atividades de promoção à Saúde e prevenção primária, além das destinadas à reabilitação e à possibilidade de melhorar a qualidade de vida dos idosos.

Figura 3 - Distribuição do número de óbitos, por faixa etária, dos moradores da área de cobertura do Centro de Saúde Integração, 1996.

\begin{tabular}{|lcc|}
\hline Faixa etária (anos) & $N^{\circ}$ & $\%$ \\
$0-\ldots 01$ & 7 pessoas & $4 \%$ \\
$01-04$ & - & - \\
$05--19$ & 7 pessoas & $4 \%$ \\
$20--49$ anos & 36 pessoas & $22 \%$ \\
$50--+$ & 117 pessoas & $70 \%$ \\
\hline
\end{tabular}


Figura 4 - Indicador de Swaroop \& Uemura, área de cobertura do Centro de Saúde Integração, período de 1990 a 1996.

\begin{tabular}{|ll|}
\hline 1990 & $68,1 \%$ \\
1991 & $68,8 \%$ \\
1992 & $72,8 \%$ \\
1993 & $70,2 \%$ \\
1994 & $69,8 \%$ \\
1995 & $70,8 \%$ \\
1996 & $70,1 \%$ \\
\hline
\end{tabular}

Fonte: Prontuário Gerencial

Figura 5- Curva de mortalidade proporcional (Nelson de Moraes), área do CS Integração, Campinas, 1996.

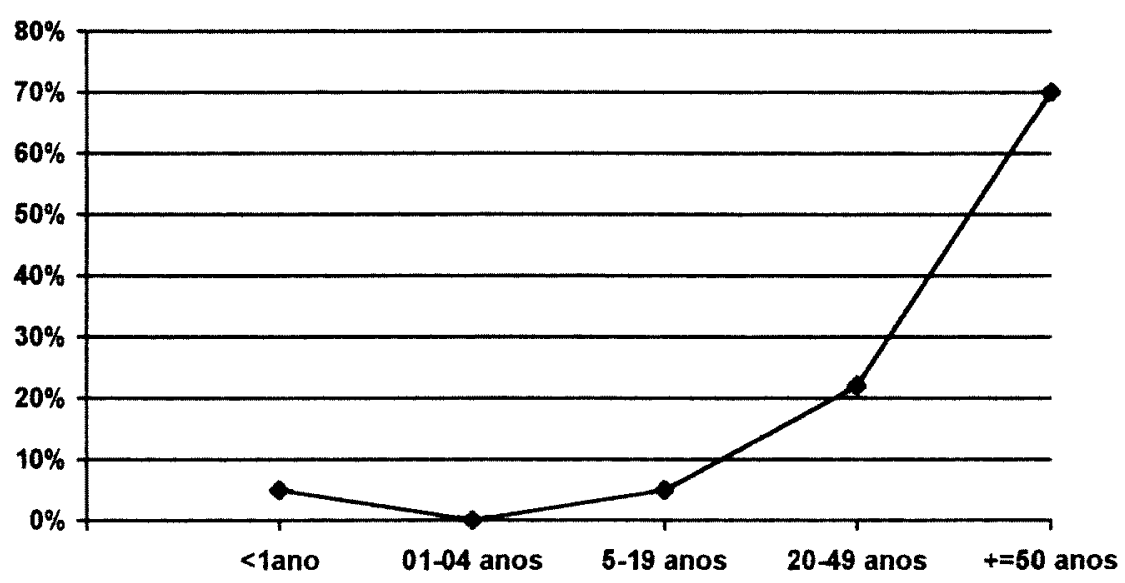

Fonte: Prontuário Gerencial 


\section{Funcionamento do Serviço}

Parece-nos oportuno, neste momento, descrevermos as atividades docenteassistenciais realizadas no CS por ocasião da coleta dos dados para o presente estudo.

A equipe de saúde mental era composta por duas psicólogas ${ }^{\star 4}$ (uma docente e uma assistencial), uma terapeuta ocupacional (docente), duas médicas psiquiatras, alunos de graduação de psicologia e terapia ocupacional e duas aprimorandas de psicologia. Esta equipe fazia atendimentos individuais e trabalhava com grupos da população.

$\mathrm{O}$ atendimento à criança era realizado por quatro pediatras em turnos de 20 horas (efetuando consultas), uma auxiliar de enfermagem atendia menores de um ano, participando também do grupo de crianças desnutridas; uma enfermeira responsável pela supervisão e trabalho de grupo; docentes e alunos de nutrição e enfermagem realizando consultas conjuntas nas ações programadas para menores de um ano e participando nas reuniões dos grupos .

$\mathrm{Na}$ atenção à mulher, atuavam três médicos ginecologistas (em turnos de 20 horas), executando consultas e, eventualmente, participando dos grupos e duas auxiliares de enfermagem (uma em cada período de atendimento). As auxiliares faziam coleta de citologia oncótica e conduziam o grupo de citologia. Uma das enfermeiras do serviço era responsável pela supervisão da área e pelo grupo de gestantes. Os acadêmicos de enfermagem, sob supervisão docente direta,

\footnotetext{
${ }^{4}$ A psicóloga (assistencial) iniciou sua atividade no CS quando terminávamos a coleta dos dados de entrevista. Pareceu-nos, portanto, conveniente que ela nāo
} 
participavam dos grupos, faziam coleta de exames e visitas domiciliares às puérperas. Os alunos de nutrição também participavam do grupo de gestantes e faziam o atendimento individual.

Prestando assistência aos adultos havia três médicos assistenciais (dois em turno de 20 horas e um com 8 horas semanais). Os docentes e alunos de medicina realizavam atendimento individual por dois períodos da semana, sendo que um dos docentes praticava acupuntura. Os médicos assistenciais realizavam consultas, supervisão em curativos e, de forma não sistemática, participavam dos grupos. A equipe se compunha de duas auxiliares (uma por período) que faziam atendimento individual e atuavam nos grupos de hipertensos, diabéticos, de medicação (hipertensos controlados) e de carteira de saúde. Aqui participavam alunos de ciências farmacêuticas, nutrição e enfermagem. Os acadêmicos dos dois últimos realizavam também atendimentos individuais. $\mathrm{O}$ atendimento aos idosos era feito no prédio do Castelinho por um docente (alunos) de medicina (dois períodos por semana) e um médico assistencial contratado pela PUCCAMP (dois períodos por semana). Os outros profissionais participavam quando solicitados.

As atividades de Vigilância Epidemiológica eram de responsabilidade do coordenador administrativo, de uma das enfermeiras e de uma técnica de enfermagem. O CS não contava com viatura própria e sim com veículo disponivel dois períodos por semana.

$\mathrm{Na}$ área de saúde bucal atuavam cinco dentistas, quatro auxiliares de consultório dentário e uma técnica em higiene dental, durante todo o período de funcionamento do Serviço, e utilizando dois equipos.

À clientela eram fornecidos atendimentos de urgência (dor), exodontia, restaurações e profilaxia de cárie dental. Este atendimento de urgência era feito no 
início dos turnos de trabalho (às $7: 30 ; 12: 30$ e 16:30 h), havendo três vagas por dentista. A agenda para tratamento dentário era aberta a cada seis meses, quando, de acordo com o número de inscrição, selecionavam-se trezentos adultos e trezentas crianças. Após a triagem, iniciavam o tratamento vinte adultos e vinte crianças. Quando estes tratamentos se completavam eram convocados mais quarenta clientes, e assim sucessivamente. As atividades com grupos eram bastante esporádicas e as ações educativas se realizavam individualmente com os pacientes. Com relação às funções dos profissionais, cabe às auxiliares colaborar no trabalho a quatro mãos com dentistas e às técnicas preparar o material para a execução das atividades, efetuando profilaxia, limpezas, restaurações e atividades educativas, como escovação supervisionada, bochechos e aplicação de flúor. Os dentistas e a equipe do CS colaboram entre si quando há encaminhamento de casos. A supervisão técnica do setor se fazia pela equipe de supervisão da Secretaria de Saúde (regional), e pelo coordenador do Serviço.

A recepção do Serviço centralizava todo o ingresso da clientela, exceto no caso de vacinação e curativos em clientes já habituais. A recepção da área de saúde bucal acontecia no próprio setor. Os profissionais de enfermagem de nivel médio trabalhavam em sistema de rodizio nas áreas ou setores de atendimento.

Apesar de contarmos com maior variedade de dados descritivos relativos às atividades desenvolvidas no Serviço, em 1996, optamos pelo trabalho com alguns deles, que podem funcionar como indicativo da eficácia de algumas ações que reúnem caráter individual e coletivo. Como exemplo, a cobertura vacinal, um indicador das açōes de vigilância à Saúde, em menores de um ano, pelo fato de não ser satisfatória para todas as vacinas.

Com relação à cobertura de citologias oncóticas, levando em conta a 
estrutura da população, e considerando $70,0 \%$ como SUS dependentes desta, os 1.724 exames realizados representam uma cobertura de $17,2 \%$ e, com relação à população total de $12,0 \%$. Chama a atenção a baixa cobertura em faixas etárias jovens e em maiores de 45 anos, o que pode significar que mulheres que utilizam outros setores do Serviço podem não estar sendo encaminhadas a esse tipo de atendimento.

A cobertura de consultas médicas (1996) foi de $18,9 \%$ e a concentração de $3,2 \%$, dados demonstrativos de insuficiência quanto ao número de médicos, principalmente em clínica médica, visto que a produtividade desses profissionais não é inferior à esperada, se considerarmos como parâmetro 12 consultas por turno de 4 horas.

\section{Análise da Demanda}

Os dados apresentados na seqüência foram obtidos primariamente na investigação realizada por Martins e Mellin ${ }^{43}$, em 1996, e são relativos à primeira hora de atendimento aos usuários. A coleta foi realizada no setor de recepção do Serviço durante dez dias úteis, no mês de novembro. A população de estudo foi composta por 346 clientes dos quais se obtiveram as seguintes informações:

Com relação a convênio médico, do total dos clientes, apenas $15(4,3 \%)$ possuíam convênio médico que não o SUS, prevalecendo a Unimed.

Da população do estudo (Tabela 1), 318 pessoas $(91,9 \%)$, eram usuárias do CS, sendo $2,1 \%$ clientes de primeira ida, o que ocorre porque o agendamento de consultas acontece uma vez por mês e, em geral, não atende às necessidades do 
Serviço e da população.

Quanto ao sexo, tivemos $26,0 \%$ de pessoas do sexo masculino e $74,0 \%$ do sexo feminino, reflexo de uma tradição de uso do Serviço principalmente pelas mulheres, tanto para acompanhar crianças, como para cuidados com sua própria saúde. Dos clientes, vimos que $84,9 \%$ eram maiores de catorze anos (adultos), dado este que se justifica pelas necessidades de Saúde deste grupo populacional, e também pela estrutura etária da população.

Com referência ao bairro de moradia, a maior demanda foi da Vila Padre Manoel da Nóbrega (32,4\%), seguida do Jardim Londres $(24,0 \%)$ e da Vila Castelo Branco $(22,0 \%)$.

O maior motivo de procura do Serviço foi para marcar consulta $(61,0 \%)$, seguido do comparecimento para consultas pré-agendadas $(28,8 \%)$ e busca por atendimentos no mesmo dia $(1,4 \%)$.

Quanto ao tempo de espera para atendimento na recepção, e posterior encaminhamento para consulta ou outro atendimento no mesmo dia, ou ainda para agendamento de outra atividade, observamos que $23,4 \%$ das pessoas esperaram menos de 15 minutos; $11,3 \%$, entre 15 minutos e meia hora; $32,4 \%$, entre 15 minutos e 1 hora e 32,9\%, mais que 1 hora, o que retrata um tempo de espera muito alto, principalmente para as pessoas que necessitam de atendimento no mesmo dia. Revela ainda entraves na recepção do Serviço, entraves estes que poderiam ser superados mediante os recursos disponíveis. Como exemplo, há o hábito de orientar as pessoas a chegarem cedo para conseguir consulta, e mesmo o de abrir agendamento para uma vez por mês. Além disso, as pessoas aguardam em fila até serem atendidas pela recepção ao passo que, se triadas por meio de um número de zhegada à porta do CS, poderiam aguardar sentadas. 


\section{Tabela 1 - Distribuição do número e porcentagem de pessoas que compareceram ao Serviço segundo a primeira ida ao Centro de Saúde Integração, Campinas, 1996.}

\begin{tabular}{ccc}
\hline $\begin{array}{c}\text { Primeiro } \\
\text { comparecimento }\end{array}$ & N. $^{\circ}$ & $\%$ \\
\hline Sim & 28 & 8,1 \\
Não & 318 & 91,9 \\
& & \\
\hline TOTAL & $\mathbf{3 4 6}$ & $\mathbf{1 0 0 , 0}$
\end{tabular}

Fonte: Martins e Mellin ${ }^{43}$

\section{Avaliação dos Usuários}

Para realização do estudo original procedemos a 101 entrevistas com clientes do serviço à saúde do CS, selecionados de maneira aleatória à saída do Serviço. ${ }^{43}$

Com relação aos dados contidos na Tabela 3, vemos que a maior parte dos clientes entrevistados ${ }^{* 5}$ pode ser considerada usuária do Serviço $(87,1 \%)$, o que ocorre nos três grupos (crianças, mulheres - atendimento ginecológico- e adultos), havendo menor índice de primeiros comparecimentos no grupo de crianças $(1,5 \%)$. No ano de 1996 , do total de consultas médicas realizadas no Serviço, cerca de $20 \%$ foram consultas de primeira vez. Esses dados indicam que a população estabelece 
vínculos mais permanentes com o Serviço. Além disso, a deficiência de clínicos e as agendas determinam, também, uma repressão na demanda espontânea.

Tabela 2- Distribuição do número e porcentagem de pessoas que compareceram ao Serviço segundo grupo etário, Centro de Saúde Integração, Campinas, 1996.

\begin{tabular}{ccc}
\hline $\begin{array}{c}\text { Grupo etário } \\
\text { (anos) }\end{array}$ & N. $^{\circ}$ & $\%$ \\
\hline Maiores de 14 & 294 & 84,9 \\
Menores de 14 & 52 & 15,1 \\
\hline TOTAL & $\mathbf{3 4 6}$ & $\mathbf{1 0 0 , 0}$
\end{tabular}

Fonte: Martins e Mellin ${ }^{43}$

De acordo com o conteúdo das entrevistas, $88,1 \%$ das pessoas mencionaram que a localização do serviço é boa, com base principalmente no fato de poderem ir a pé. No grupo das mulheres houve maior propensão de não se sentirem satisfeitas com a localização do Serviço $(41,7 \%)$, o que pode ser explicado pelo fato de o CS servir como referência para o eixo John Boyd, e também porque algumas delas não residiam na região próxima.

Com relação ao tempo de espera para o agendamento de consultas vemos que $64,4 \%$ dos entrevistados considera-o demorado, principalmente as mães ou acompanhantes de crianças $(85,0 \%)$. Esse dado provavelmente reflete a preocupação das mães com a saúde de seus filhos e a dificuldade para 
agendamento já descrita. Apesar dessa opinião das mães, identificamos no Serviço maior facilidade e rapidez para agendamento de consultas na área da criança em relação às demais áreas, principalmente à do adulto.

Entre as mulheres e os adultos, figura ainda a resposta agendamento rápido, quando conseguem consulta no mesmo dia $(18,8 \%$ e $8,2 \%)$, respectivamente. 0 tempo excessivamente demorado, para o agendamento das consultas com o clínico, foi atribuido pelos entrevistados à falta de médico.

Quanto ao tempo de espera para o atendimento no $\mathrm{CS}$, temos que a maior parte dos entrevistados considerou-o demorado (47,5\%). Principalmente no caso de mulheres $(37,5 \%)$ e adultos $(55,6 \%)$, os índices de satisfação traduzidos como bom e rápido chegam a $44,5 \%$.

Pudemos observar que muitas vezes o tempo demasiado grande de espera ocorre quando o usuário chega muito cedo ao Serviço. Tal situação acontece quando a clientela busca atendimento médico por meio de encaixe, sem consulta previamente agendada.

Com relação às acomodações do CS, a maior parte dos entrevistados considera que são muito boas ou adequadas $(70,7 \%)$, enfatizando a limpeza. Apesar da consideração anterior, muitos sugerem melhorias como: realização de cobertura externa (para os dias de chuva) e cadeiras no exterior. A maior porcentagem de insatisfação $(51,7 \%)$, dá-se entre as mulheres que se queixam, principalmente, dos sanitários, considerados pequenos, em número reduzido e muitas vezes fechados. Dos seis sanitários existentes no Serviço, vários deles foram, com o tempo, destinados para outras finalidades: um foi reformado e transformado em pequeno expurgo (local para limpeza de instrumentos antes da esterilização, até então inexistente no Serviço); outro, é utilizado para depósito de 
roupas. Assim restaram dois banheiros destinados ao uso da equipe de trabalho (funcionários, professores e alunos), e apenas dois para uso do público. Convém lembrar que estes locais não se encontravam devidamente equipados com papel higiênico, papel-toalha e sabonete.

Quanto à indicação do CS, $67,3 \%$ dos entrevistados disseram que o indicariam, por causa do bom atendimento; $5,0 \%$, porque há bons médicos e $7,5 \%$, pela proximidade. Três dos entrevistados não indicariam o Serviço $(3,0 \%)$.

Os entrevistados justificam as considerações de que o atendimento do CS é bom assim se expressando: "atendimento das necessidades"; "atendem nossos pedidos" e "toda a família trata no Posto e gosta".

Ao responderem sobre os o motivos de procura do Centro de Saúde, $52,3 \%$ colocam a sua proximidade como fator preponderante e $33,6 \%$ dizem que gostam do atendimento. Apenas $6,3 \%$ dos entrevistados utiliza o Serviço por falta de outra opção.

Tabela 3 - Distribuição do número e porcentagem de usuários, segundo condição de atendimento e grupos, CS, Integração, Campinas, 1996.

\begin{tabular}{|c|c|c|c|c|c|c|c|c|}
\hline \multirow{2}{*}{$\begin{array}{c}\text { Primeiro } \\
\text { Atendimento }\end{array}$} & \multicolumn{2}{|c|}{ Criança } & \multicolumn{2}{|c|}{ Mulher } & \multicolumn{2}{|c|}{ Adulto } & \multicolumn{2}{|c|}{ Total } \\
\hline & n. ${ }^{\circ}$ & $\%$ & n. & $\%$ & n. ${ }^{\circ}$ & $\%$ & $n .^{\circ}$ & $\%$ \\
\hline \multirow[t]{2}{*}{ Sim } & 01 & 5,0 & 05 & 15,6 & 07 & 14,3 & 13 & 12,9 \\
\hline & \multicolumn{2}{|c|}{$(7,7)$} & \multicolumn{2}{|c|}{$(38,5)$} & \multicolumn{2}{|c|}{$(53,8)$} & \multicolumn{2}{|c|}{$(100,0)$} \\
\hline \multirow[t]{2}{*}{ Não } & 19 & 35,0 & 27 & 84,4 & & 85,7 & & 87,1 \\
\hline & \multicolumn{2}{|c|}{$(21,6)$} & \multicolumn{2}{|c|}{$(30,7)$} & \multicolumn{2}{|c|}{$(47,7)$} & \multicolumn{2}{|c|}{$(100,0)$} \\
\hline \multirow[t]{2}{*}{ TOTAL } & 20 & 100,0 & & 100,0 & & 100,0 & 101 & 100,0 \\
\hline & \multicolumn{2}{|c|}{$(18,8)$} & \multicolumn{2}{|c|}{$(31,7)$} & \multicolumn{2}{|c|}{$(48,5)$} & & \\
\hline
\end{tabular}


Quando questionados sobre se gostam do Serviço, com a especificação das diversas áreas de atendimento nele contidas, obtivemos a resposta de que: $82,2 \%$ dos entrevistados gostam do atendimento da recepção, pois consideram as funcionárias atenciosas, educadas e simpáticas. Aqueles que informam não gostar do atendimento $(17,8 \%)$, alegam que

"Algumas pessoas não tratam bem"; "é dificil pegar uma pessoa de bom humor"; "sempre tem uma desculpa para não encaixar consulta"; "demora para atender"; "algumas pessoas são estúpidas".

A recepção de qualquer Serviço constitui-se em seu cartão de visita, daí a importância de se fazer de forma adequada o acolhimento da clientela no setor. Entretanto, sabemos da dupla pressão que sofrem os funcionários do setor. Pois, ao mesmo tempo que recebem a solicitação dos usuários para atendimento elou consulta médica, encontram-se na posição/papel de limitar a oferta dos serviços em função da capacidade de atendimento. Tal situação gera desgaste para o funcionário e insatisfação no usuário. Vemos ainda que é fundamental o treinamento dos funcionários e a identificação de pessoas com perfil adequado para essa atividade.

Com relação à equipe de enfermagem, 57,3\% dos entrevistados manifestam gostar do atendimento nas áreas de vacinação, curativo, inalação, verificação de pressão arterial, dentre outras, pois "tratam com eficiência e educação", "são atendidos na hora". Os usuários que não aprovam o trabalho de enfermagem (4,0\%), falam da "demora para atender" e que "não sabem fazer curativo". Uma parcela significativa da clientela 
$(23,7 \%)$ informa não se utilizar do atendimento da enfermagem.

É alta a opinião positiva $(87,1 \%)$ a respeito da consulta médica, seguida das justificativas: "o médico olha a criança do pé até a cabeça"; "explica e orienta bem"; "o médico é atencioso". Apenas $11,9 \%$ dos entrevistados não consulta os médicos do Serviço. Na pesquisa obtivemos a informação de que $4,3 \%$ dos entrevistados possuíam plano de saúde, utilizando-se de outros médicos. Os atendimentos na área da farmácia foram bem avaliados pela maioria dos entrevistados, pois "dá os remédios certos"; "encontra os remédios de que precisamos" e ainda porque, "as pessoas são ótimas, atendem muito bem". A opinião negativa para esta área se relaciona, especialmente, ao fato de que, às vezes, não há o medicamento prescrito.

Embora o Serviço disponha de uma equipe para saúde mental (psiquiatra, psicólogo, terapeuta ocupacional), e que serve, inclusive, como referência para o eixo Dunlop, a maioria dos entrevistados não se utiliza desta área. Situação semelhante encontramos em nutrição e fisioterapia.

Diante do exposto no presente capítulo faremos algumas consideraçōes relativas à mudança das características dos CS:

A própria implementação do SUS e os princípios de reconhecimento da saúde como direito, da universalização, da equidade e da integralidade do cuidado impuseram novo caráter aos Serviços Básicos de Saúde que, de acordo com Paim $^{57}$, devem realizar seu planejamento local, com vistas às necessidades das populações a eles adstritas.

Os Postos de Saúde municipais, desde o início, tinham caracteristicas de atendimento à demanda por assistência à Saúde, com práticas simplificadas contidas nos princípios da atenção primária à saúde. Funcionavam em casas 
alugadas e tinham muita articulação com as populações das áreas de abrangência, seja pelas preocupações dos médicos envolvidos no projeto, seja pela forma de seleção e treinamento dos auxiliares de saúde ${ }^{37,69}$ Com o passar do tempo e, em decorrência da incorporação de mais funções, constituem-se em Centros de Saúde com estrutura de recursos físicos e materiais ampliada. Absorveram, além disso, maior número de profissionais, com qualificação técnica de maior nível. ${ }^{11,12}$ Desta forma, os Postos de Saúde nos quais atuavam médicos generalistas e auxiliares de saúde, recebem entre seus funcionários os enfermeiros, técnicos e auxiliares de enfermagem, clínicos, pediatras e ginecologistas. Cabe destacar que, atualmente, muitos serviços contam com dentistas; psiquiatras; psicólogos e outros profissionais de saúde. Assim, é modificada a característica dos CS. Houve, como vimos, mudanças no modelo assistencial e no modo de inserção dos profissionais na rede de serviços, anteriormente mais familiares, o que induz ao pensamento de que essa nova configuração mereça, de nossa parte, maior atenção, se quisermos compreender a nova realidade. Cabe agora alguns questionamentos relativos aos CS em si:

Vimos que, os serviços ganharam maior capacitação e poder de atendimento às necessidades da saúde da população. Conseguiram, paralelamente, consolidar seu caráter público? Como sentem este caráter os profissionais de saúde, na prática profissional? O discurso da reforma sanitária é compreendido por eles? Houve compartilhamento?

Como se constitui o projeto de Reforma Sanitária quando não há aderência das pessoas (profissionais de Saúde) a ele?

Para atender a tais questionamentos procuramos nos aproximar dos modos de pensar dos profissionais de Saúde do CS Integração, acessando suas 
Representações Sociais, cabendo uma explicação sobre a origem teórica do termo aqui utilizado. 


\section{III- Representações Sociais -}

\section{Fundamentação Teórica}

No sentido de oferecer uma melhor compreensão sobre a teoria das Representações Sociais fizemos um resgate bibliográfico exposto em seqüência.

Vemos em Sá ${ }^{62}$ que o termo Representações Sociais (RS) é utilizado como forma de designar tanto um conjunto de fenômenos quanto o conceito que os engloba, isto é, a teoria construida para explicá-los.

De acordo com Vala: "Representações Sociais são teorias implícitas acerca de objetos relevantes e como tal constituem uma modalidade do conhecimento que serve para apreensão avaliação e explicação da realidade." (Pág.: 5)

A teoria das RS foi elaborada por Serge Moscovici, ${ }^{50,62}$ tendo sido abordada em primeira instância na sua obra publicada em 1961, na França, cujo título em português é: "A Representação Social da Psicanálise", ${ }^{53}$ estudo relativo às RS da psicanálise, na sociedade francesa. Esta teoria surgiu como uma alternativa à Psicologia Social fortemente influenciada pela tradição americana de centrar os 
estudos nos aspectos relativos ao indivíduo, no exercicio de papéis sociais. ${ }^{24}$ Para elaborá-la Moscovici recorreu a Durkheim e ao conceito de representações coletivas por ele formulado. Nesse sentido, para Sá, ${ }^{2}$ Durkheim partia da idéia de que: “... os indivíduos que compõe a sociedade seriam portadores e usuários das representações coletivas que não poderiam ser reduzidas a algo como o conjunto das representações individuais das quais diferiam.". (Pág.: 21)

Segundo Moscovici: ${ }^{53}$ "Representar uma coisa (...) não é com efeito simplesmente duplicá-la, refleti-la ou reproduzi-la; é reconstituí-la, retocá-la, modificar-Ihe o texto". (Pág.: 58)

De acordo com Sá, ${ }^{2}$ Moscovici busca as RS da sociedade presente, admitindo que o conjunto dos conceitos nascem da teoria do senso comum. Assim, a gênese das RS dá-se nas mesmas circunstâncias (históricas, sociais) em que se manifestam por meio das conversações entre as pessoas. Partindo do princípio de que nas sociedades contemporâneas coexistem duas classes distintas de pensamentos, divididos no que foi denominado universos reificados e universos consensuais.

Os universos reificados são bastantes circunscritos aos locais onde se reproduzem e circulam as ciências e o pensamento erudito em geral. Aos universos consensuais correspondem atividades intelectuais da interação social cotidiana pelas quais são produzidas as RS. As teorias do senso comum neles elaboradas utilizam mecanismos de verificação diferentes (não usam o método científico) e são menos sensiveis aos requisitos de objetividade. Em contrapartida, captam sentimentos compartilhados por verossimilhança e plausibilidade. Ainda segundo Sá, ${ }^{62}$ a matéria-prima das RS provém dos universos reificados. 
Com relação à questão do conhecimento do senso comum ele pode ser sub dividido em duas modalidades: a primeira, definida como conjunto de conhecimentos gerado por um grupo com base na tradição e no consenso; e a segunda determinada por uma apropriação das noções, linguagens e imagens cientificas veiculadas pelos meios de comunicação. ${ }^{62}$

De acordo com Moscovici, ${ }^{54}$ as RS são resultado da transformação do não familiar em familiar, isto é do desconhecido em conhecido, partindo dos Universos Reificados e decorrentes de uma releitura realizada pelos sujeitos sociais. As RS abarcam conceitos (a partir dos sujeitos) e percepções (a partir dos objetos), envolvendo aí a subjetividade e a objetividade que mantêm permanente diálogo. Uma realidade social, como entendida pela teoria das RS, é criada apenas quando o novo ou não familiar vem a ser incorporado aos universos consensuais. Ainda segundo Moscovici: ${ }^{53}$ "É profunda a propensão para dar uma existência conosco à aquilo que tinha uma existência sem nós, para nos fazer presentes onde estamos ausentes, familiares em face do que nos é estranho.". (Pág.64). Nas representações: “...está contida uma profunda tensão entre o pólo passivo da estampagem do objeto - a figura - e o pólo ativo da escolha do sujeito - a significação que ele the dá e de que ele está investido.". (Pág. .55). Desta forma há duas faces indissociáveis: figura e sentido, isto é, "... a cada figura corresponde um sentido e, a cada sentido, uma figura".

A formação das RS, para Moscovici, ${ }^{54}$ dá-se por dois processos: objetivação e ancoragem. Ancorar é classificar e denominar. A classificação dá-se a partir de paradigmas ou protótipos (modelos) estocados na memória com os quais comparamos o objeto a ser representado e decidimos se ele pode, ou não, ser incluido numa ou noutra classe. A denominação das coisas significa tirá-las de um 
anonimato (que pode ser perturbador), para dotá-las de uma genealogia, isto é, a fim de conhecermos o seu passado (origem). A objetivação constitui-se em uma operação mental imaginante ou estruturante na qual um conceito abstrato fica quase tangível e pode ser materializado por meio da palavra. ${ }^{54}$

Moscovici ${ }^{53}$ conceitua que as RS são relativas a idéias estocadas que, por sua vez, se relacionam à concepções religiosas e políticas, por exemplo, o que conforma o pensamento cotidiano e cria conexão com as formas de pensamento e expressão

De acordo com Jodelet. ${ }^{35}$

"A Representação Social é definida por um conteúdo, informações, imagens, opiniões, atitudes que se relacionam à um objeto, trabalho a realizar, acontecimento econômico e personalidade social. Por outro lado é a representação de um sujeito

(indivíduo, grupo, sociedade), relacionada à outro sujeito. Desta forma a representação é derivada da posição que os sujeitos ocupam na sociedade".

(Pág.: 475)

Ainda para Jodelet, ${ }^{35}$ as RS nos colocam na interface entre 0 social e o psicológico. Deste modo, são relativas às formas como os sujeitos são capazes de captar as coisas da vida e o conhecimento do senso comum. Daí, participarem da construção social da realidade. Deste modo, devem ser abordadas de duas maneiras, enquanto produto e enquanto um processo de elaboração psicológica e social da realidade, designando assim uma forma de pensamento social. ${ }^{35}$

Spink ${ }^{72}$ comenta:

"Enfocadas como processo, as representações emergem como pensamento constituinte ou núcleos estruturantes. Nessa perspectiva a pesquisa volta-se à compreensão da elaboração e transformação das representações sob a força das determinações sociais, ou à compreensão do funcionamento e eficácia das representações na interação social.". (Pág.:91) 
Para a autora pode-se utilizar este enfoque ao pretender-se esclarecer as determinações sociais que são conseqüência da posição ocupada na sociedade pelos diferentes atores sociais. Também, para que haja explicitação dos: "...modelos coletivos disponiveis para que 0 indivíduo possa dar sentido a sua experiência social.". (Spink, ${ }^{72}$ pág.:91)

Vemos, deste modo, que as RS não são estanques, nem estagnadas, mas estão em mudança, tanto no interior de um mesmo grupo, como podem ser distintas em diferentes grupos.

Jodelet $^{35}$ estabelece cinco caracteristicas fundamentais das RS:

"São sempre a representação de um objeto. Possuem um caráter de criação de imagem e a propriedade de possibilitar o intercâmbio entre o "sensivel" e a idéia, a percepção e o conceito. Possuem caráter simbólico e significante. Possuem caráter construtivo. Possuem caráter autônomo". (Pág.: 478)

As pesquisas, cujo objeto são as RS, possibilitam várias formas de aproximação e apreensão das representações, embora seja importante ressaltar que a maior expressão delas, se dê por meio da palavra. Assim, de acordo com Spink $^{72}$, a forma mais comum de acessar as representações são as técnicas verbais, o que se dá, particularmente, quando se realizam estudos do nível individual, pois os de caráter mais geral podem servir-se de documentos e outros tipos de registros.

A autora ${ }^{72}$ ainda ressalta haver nítida preferencia pelo uso de entrevistas abertas, conduzidas por um roteiro mínimo, o que permite a expressão mais livre do entrevistado, sem imposição de pré-concepções e categorias do pesquisador. Deste modo, o material obtido traz maior riqueza quando se refere às práticas sociais de importância para a investigação. 
Para Souza Filho, ${ }^{70}$ a coleta de dados relativos às RS deve ser feita em situação a mais próxima possivel da realidade natural em que ocorre o fenômeno, isto é, o pesquisador deve ter acesso à realidade dos sujeitos em sua relação tanto com o objeto de representação, como com outros sujeitos. Os meios de que o investigador pode dispor para isso são a observação participante ou as entrevistas com roteiros abertos, mesmo que contenham eixos catalisadores.

De acordo com Minayo, ${ }^{51,52}$ a entrevista difere do questionário que supõe hipóteses e questões bastante fechadas, pois contém poucas questões e serve como instrumento para orientar uma conversa, com finalidade. A elaboração do roteiro pressupōe conhecimento do marco teórico e do objeto. Essa aproximação do objeto, por meio do uso da técnica de entrevista, implica que o entrevistador conduza uma conversa com finalidade o que, de acordo com Thompson ${ }^{80}$, pode darse por uma aproximação sucessiva por meio de entrevistas-padrão, permitindo ao pesquisador compreender a melhor forma de abordagem dos sujeitos. Para Good \& Hatt, ${ }^{33}$ o roteiro da entrevista exige certos itens de informação, mas possibilita ao entrevistador expressar-se da forma mais adequada à compreensão do entrevistado.

Ao tratarmos das questões metodológicas dos estudos que utilizam como referencial a teoria das RS recorremos à Spink, ${ }^{72}$ para quem, as pesquisas relativas às RS constituem a articulaçāo dos quatro níveis identificados por Doise (apud Spink $^{72}$ :

"... o nivel dos processos intraindividuais que focaliza a maneira em que os individuos organizam suas experiências do social nivel este privilegiado entre outros pela psicologia cognitiva; o nivel dos processos interindividuais ou intersituacionais enfocado por grande parte das pesquisas em dinâmica de grupo; o nível situacional propriamente dito em que se inserem as pesquisas que exploram as diferenças 
(quanto ao poder, identidade social, etc.) resultantes da posição ocupada em um determinado campo social; o nivel ideológico, no qual situam-se as análises sobre as visões de mundo de determinadas sociedades, classes ou segmentos de classes". (Pág.: 89)

Parece-nos importante compreender que essa subdivisão da pesquisa em niveis é recurso formal para possibilitar ao pesquisador uma melhor compreensão do escopo de cada estudo. Deve, também, ficar claro que uma pesquisa pode darse pela articulação de um ou mais níveis. Compreendemos, além disso, a dificuldade em desarticular o nivel ideológico dos demais

Em posse do material empírico relativo às $R S$, cabe ao pesquisador a tentativa de aproximação do objeto, o que traz uma nova perspectiva de análise. Para Wagner: ${ }^{82}$

"O conceito de representação social é multifacetado. De um lado, a representação social é concebida como um processo social que envolve comunicação e discurso, ao longo do qual significados e objetos sociais são construidos e elaborados. Por outro lado, e principalmente no que se relaciona ao conteúdo de pesquisas orientadas empiricamente, as representações sociais são operacionalizadas como atributos individuais, como estruturas individuais de conhecimento, simbolos e afetos distribuídos entre as pessoas em grupos e sociedades.". (Pág.:149)

Essa plasticidade do conceito e o fato de a teoria em questão estar inacabada permitem diversas interpretaçōes dos dados, e muitas vezes uma certa inadequação. Ainda de acordo com Wagner, ${ }^{82}$ qualquer teoria se preocupa em descobrir e compreender o fenômeno estudado, buscando conceitos de ordem processual e causal. A teoria das RS trabalha com os saberes do senso comum, havendo facilidade em conceber o que seja a representação. Por outro lado, é difícil compreender o que a representação explica. 
Para responder a esse questionamento, Wagner ${ }^{82}$ propõe a adoção de um modelo explicativo denominado "explicação modal" diverso do modelo dedutivonomológico, adequado às diversas ciências, e assim definido pelo autor:

"Segundo esse modelo, uma explicação dedutivo nomológica válida necessita um conjunto de leis abrangentes e um conjunto de condições antecedentes. Essas condições antecedentes são, elas próprias, instâncias dos termos relevantes das leis abrangentes e especificam as características do evento a ser explicado".(Pág.:151)

De acordo com o autor ${ }^{82}$ a teoria das RS, bem como outras da Psicologia Social, requerem um modelo de explicação simplificado por ele denominado "modelo soft" ou de explicação modal na qual se estabelece uma relação sintética do tipo se - então. Assim:

"Uma proposição é uma explicação modal se: a) existe o fenômeno q; b) se existe uma relação entre o fenômeno $q$ e o fenômeno $p$ de tal forma que $q$ implica em $p$. Essa proposição explica o fenômeno $p$ pela condição antecedente $q, s e, e$ somente se, a implicação não se mantiver para o contrário de q, Não - q.". (Wagner, ${ }^{82}$ pág.:153)

Considerando o modelo explicativo proposto, as pesquisas podem ater-se ao nivel de avaliação individual, quando a representação de um dado fenômeno é apreendida por meio da obtenção da representação prototípica, dada pela intercessão dos conteúdos de cada representação individual, denominados núcleos centrais, cabendo ressaltar que a existência de dado processo social explica que ocorre individualmente, cujas representações podem constituir-se como fatores que expliquem comportamentos posteriores.

Parece importante, no momento, a explicitação da dificuldade em se trabalhar com a teoria das RS, o que significou mais que um desafio. ${ }^{71}$ Dada sua complexidade intrínseca, o que se agrava diante dos conteúdos empíricos, cuja 
análise implica criatividade e sensibilidade por parte do pesquisador. Há questões novas e de difícil abordagem, o que se deve também ao caráter interdisciplinar, marcante no presente estudo, em que busquei a compreensão das práticas da Saúde Pública utilizando um percurso comum à Psicologia Social. 


\section{IV- Objetivos}

\section{IV-1- OBJETIVO GERAL}

Conhecer as Representações Sociais sobre as finalidades e os pressupostos teóricos que norteiam as práticas dos atores sociais (profissionais de saúde) relacionando-as à vivência do Modelo Assistencial do Centro de Saúde Integração.

\section{IV-2- OBJETIVOS ESPECÍFICOS}

- Descrever as trajetórias dos profissionais de Saúde, com atuação no Centro de Saúde Integração.

- Identificar nos profissionais de Saúde, com atuação no Centro de Saúde Integração, Representações Sociais sobre a natureza, a finalidade e as práticas do Serviço. 
- Estabelecer pontos comuns e divergentes nas representações dos diversos profissionais acerca da natureza, das finalidades e práticas do Serviço.

- Estabelecer as implicações dessas representações no modelo de atenção à saúde. 


\section{V -PERCURSO METODOLÓGICO}

\section{V-1- SITUAÇÃO ATUAL DO PROBLEMA EM QUESTÃO}

Durante a década de 80 ocorreram inúmeras transformações no setor Saúde visando a proposta de Reforma Sanitária Nacional. Tais transformações tiveram em sua maior parte cunho racionalizador e de melhora na estrutura da rede pública de Serviços de Saúde, com maior ênfase aos Serviços Básicos que tendem, no periodo, a rever modelos assistenciais tornando-se, porta de entrada do Sistema. Esse projeto foi bastante enfatizado durante a $8^{\mathrm{a}}$ Conferência Nacional de Saúde e a Carta Constitucional de Saúde de $1988^{14,31}$

Paralelamente a essa tendência de visão da Saúde, como dever do Estado e direito do cidadão, há todo um projeto neoliberal que preconiza o Estado mínimo e que tomou maior corpo, no Brasil, com a eleição presidencial de 1989. Dentro desse contexto há, no período, um grande sucateamento da rede pública e formulações políticas pouco claras, tanto na articulação da rede, como no financiamento do 
Sistema. Enfrenta-se, no momento, grande crise nacional, piora nos indicadores de saúde, amplia-se o quadro de doenças endêmicas e epidêmicas de maior gravidade. Além disso há uma sobrecarga nos deveres dos municípios com a prestação de assistência à saúde.

Nos Serviços Básicos também se observa a lógica da prestação de assistência médica de cunho individual e curativo e a falta do caráter integral nas ações de saúde.

Configura-se, além disso, uma provável desarticulação do chamado movimento sanitário nacional, no qual se percebe vivência completamente dicotomizada entre quem formula políticas de prestação de assistência à saúde (os teóricos) e quem executa trabalhos cotidianos nos Serviços de Saúde (os práticos). No mais das vezes, são ações reprodutivas de modelos assistenciais incompativeis com os pressupostos das transformações sociais, destituidas de compromisso real com a população e 0 atendimento às suas reais necessidades.

Ademais, os profissionais de Saúde dão à sua inserção nos serviços básicos e públicos o mesmo caráter que teria em qualquer local ou instituição de prestação de assistência. Há ainda uma espécie de contradição entre o discurso e a compreensão do serviço de gerentes, que tendem a apresentar um pensamento mais voltado para qualificação do serviço, e a compreensão dos executores (médicos, enfermeiros, auxiliares de enfermagem, dentistas e outros profissionais de saúde). A maior parte dos gerentes tem formação esscúlāi ưi mîesiñú uimin perfil profissional que Ihes deveria conferir maior capacidade de pensar a prática dos serviços. Os sanitaristas têm por tradição uma preocupação maior com o caráter social da medicina. Já os outros profissionais não costumam ter acesso a esse tipo de valor. Cabe ressaltar que, nem sempre, os gerentes possuem formação em 
Saúde Pública, mas sua própria inserção nos serviços thes confere maior possibilidade de aprender sobre aspectos mais globais da atenção à saúde.

Mesmo diante dessas considerações sobre a qualidade da inserção de alguns profissionais, vemos que todos eles são, na prática, os diferentes sujeitos sociais, ocupando espaços da gerência e da assistência. Tais profissionais executam as políticas de saúde em seu aspecto micro e o fazem segundo sua própria visão de mundo.

Dentro da perspectiva da Reforma Sanitária, qualquer medida de planejamento, programação e avaliação de Serviços de Saúde deve fundamentar-se nas formas de pensar subjacentes às práticas profissionais, tanto para compreendêlas, como para formular estratégias e modificá-las.

Na realidade do Centro de Saúde Integração convivem os coordenadores com vínculo com a Universidade (acadêmico) e com a Secretaria de Saúde (administrativo), docentes e os profissionais assistenciais contratados pela Secretaria da Saúde (enfermeiros e equipe de enfermagem, médicos, dentistas e equipe de odontologia). Portanto, até mesmo neste nivel de atividade a divisão do trabalho relaciona-se, em princípio, com as atitudes e posturas dos profissionais. Também o cotidiano do serviço proporciona a conformação de um dado modelo e mesmo, de um dado discurso que cabe a cada um reproduzir. ${ }^{7}$ Partindo dessas reflexões, elaboramos o estudo a seguir delineado. 


\section{V-2- PRESSUPOSTOS PARA INVESTIGAÇÃO}

Constituíram-se como pressupostos, do presente estudo, que as transformações sociais gerais e aquelas do setor Saúde não ocorrem, exclusivamente, por meio de decreto e legislação. Dependem do compromisso da sociedade e, no caso da Saúde, especificamente, dos profissionais de Saúde, coma os direitos das pessoas.

Parece ainda não haver uma linha definida na relação entre os principios teóricos que respaldam o projeto da Reforma Sanitária e a prática dos trabalhadores dos Centros de Saúde, o que poderia conferir a eles maior organicidade visando o objetivo da consolidação da cidadania. Sendo essa uma lacuna fundamental, há necessidade de investimentos na articulação entre objetivos e missões.

Os profissionais de Saúde, em sua prática nos Centros de Saúde, trazem para o trabalho uma dada visão de mundo, no mais das vezes, não comprometida com as transformações da sociedade. Também não tem sido explicitado 0 que se espera deles, ou seja, que sua atuação profissional é também política e que transformações na Saúde passam pelo envolvimento de todos os trabalhadores. Parece ainda que os conceitos de cidadania (direito à saúde, universalização, integralidade), do caráter público do serviço de saúde, e mesmo estratégias para viabilizar uma prática coerente com esses princípios não têm sido assunto de discussão que possibilite maior compreensão acerca do objeto da atuação profissional nos CS.

As ações de planejamento e gestão dos Serviços costumam ficar a cargo dos 
gerentes e, no mais das vezes, não são compartilhadas por profissionais e usuários, o que não contribui para a difusão e apropriação das diretrizes teórico-conceituais. Tal atitude torna o fazer fragmentado, descolado da realidade, cuja finalidade é o simples cumprimento de tarefas, sem que a situação se modifique. Quando muito, o atendimento é remediável.

Considerando ainda as diferentes formas de inserção dos profissionais no Serviço, o maior ou menor valor atribuido a seu saber específico e às suas atribuições, o que é determinado pelo modelo assistencial. O fato de muitos deles, particularmente em nosso caso, vincularem-se à Universidade. Vemos que, de acordo com sua inserção na unidade, divergem as abordagens sobre o objeto de trabalho.

Para que possa haver algum propósito de mudança, embasado na lógica do conhecimento da realidade, procuramos avaliar em que medida as Representações Sociais dos profissionais de Saúde correspondem aos pressupostos norteadores desse estudo.

\section{V-3- DELIMITAÇÃO DO ESTUDO}

O objeto de trabalho, do presente estudo, são as Representações Sociais dos sujeitos sociais (profissionais de saúde) que atuam no Serviço, relativas às finalidades e práticas do Centro de Saúde Integração. Foram obtidas por meio das falas desses profissionais, entendidas como forma de expressão dessas representações. Fizemos tal opção baseados no referencial teórico e nas 
colocações de Queiroz, ${ }^{59}$ para quem o relato oral serve para captar o não explícito e, até mesmo, o indizível.

Utilizamos o termo sujeito, adotando a noção de que ele seja portador tanto de autonomia, quanto de heteronomia, tal como foi utilizado por Sader, ${ }^{63}$ para quem:

"As noções de ator e de agente. (...) são portadoras de uma tradição sociológica que justamente definia o primado do sistema social. $\mathrm{O}$ ator social, como aquele que representa um papel, designava o portador de papeis definidos no nivel da estrutura social.". (Pág.:54)

Compreendemos tais sujeitos, como agentes de transformação da realidade dentro de uma perspectiva de relação em que ocorre diálogo entre ambos (sujeitorealidade). De acordo com Sader: ${ }^{63}$

"Ora os sujeitos estão implicados nas estruturas objetivas da realidade. Se considerarmos que a chamada "realidade objetiva" não é interior aos homens, mas está impregnada dos significados das ações sociais que a constituíram enquanto realidade social, temos também de considerar os homens não como soberanos indeterminados, mas como produtos sociais". (Pág.:54)

Estudando as Representações Sociais destes sujeitos, não pretendemos descobrir o novo, mas sim compreender melhor os aspectos da realidade na qual ocorre as práticas sociais. ${ }^{18}$

Gonçalves, ${ }^{32}$ também dentro da perspectiva de uma melhor compreensão dos modos de produção de serviços nos Centros de Saúde, trabalhou com as Representações Sociais usando dois meios de aproximação: as representaçōes dos trabalhadores e as caraterísticas do processo de trabalho. Trazemos aqui um trecho do estudo deste pesquisador, para clarear os aspectos de relevância temática: "Assim se legitima a proposta de apreender os processos de produção de serviços de saúde através da apreensão das representações sobre esse processo de que 
são portadores os agentes que dele participam...". (Pág:45)

O autor ${ }^{32}$ coloca ainda a particularidade das representações enquanto um produto não objetivado: "... assim também se estabelecem delimitações nessa apreensão, pois se renuncia ao conhecimento dos produtos objetivados, e mesmo de características desses processos que ultrapassam o alcance dessas representações". (Gonçalves, ${ }^{32}$ pág.: 45)

Para entendermos melhor o papel dos sujeitos recorremos a Merhy, ${ }^{44}$ para quem os sujeitos sociais, como sujeitos políticos, se caracterizam a partir de seus projetos, em torno dos quais articulam os próprios interesses e expōem suas vontades, como ação.

Vemos em Minayo51: "Hoje a questão do homem enquanto ator social ganha corpo e faz emergirem, com toda sua força, as ciências sociais que se preocupam com os significados".(Pág.: 33)

Como já foi dito, a medicina é uma prática do Social e, nos serviços de Saúde, somos os executores finais das políticas sociais. O espaço do Centro de Saúde é campo de interação dos diversos sujeitos sociais onde se veiculam políticas, saber e poder. Constituindo-se em espaço micropolítico de acordo com o proposto por Foucault, ${ }^{26}$ em Microfísica do Poder. No cotidiano do serviço, os diversos profissionais de Saúde relacionam-se entre si e com a clientela. A escolha das representações desses sujeitos, como objeto de investigação, respalda-se em Offe, ${ }^{55}$ para quem o ator social, nas instâncias da Educação e da Saúde, é o responsável final pela execução das Políticas de Saúde.

Também com base em Offe, Gershman ${ }^{30}$ comenta que:

"O papel dos atores é fundamental para recompreender inovações políticas 
e-ou processos de racionalizações administrativas equacionadas na

compatibilização ou adequação de estratégias políticas". (Pág.: 132)

Vemos, também, que, no cotidiano do serviço os diversos profissionais de saúde relacionam-se entre si e com a clientela, o que caracteriza relações de trabalho e assistência e, mesmo, poder. Ai se configura um dado modelo, também dependente da forma como são estabelecidas tais relações. Nesse dia a dia, a cena revela esses profissionais como protagonistas (ou não).

\section{V-4- JUSTIFICATIVA DO USO DO MÉTODO}

Para Minayo:

"As Representações Sociais se manifestam em condutas e chegam a ser institucionalizadas, portanto, podem e devem ser analisadas a partir da compreensão das estruturas e dos comportamentos sociais. Sua mediação privilegiada porém é a linguagem do senso comum tomada como forma do conhecimento e de interação social". (Pág.: 173)

Assim, a aproximação do objeto deu-se a partir das falas dos sujeitos. Foi feita, nesse sentido, uma busca das representação dos profissionais acerca dos conceitos que respaldam a teoria e o próprio projeto de reforma sanitária.

Ao analisar a importância da expressão livre dos sujeitos vemos em Sader: ${ }^{63}$ "O discurso que revela a ação revela também o seu sujeito", assim "... a linguagem não é um mero instrumento que serve para comunicar alguma coisa que já existisse independentemente dela". (Pág.: 57)

De acordo com Lane: ${ }^{38}$ 
"A linguagem, como produto de uma coletividade, reproduz através dos significados das palavras articuladas em frases os conhecimentos verdadeiros e os valores associados às práticas sociais que se cristalizam; ou seja a linguagem reproduz uma visão do mundo, produto das relações que se desenvolveriam a partir do trabalho produtivo para a sobrevivência do grupo social". (Pág.: 32)

Tendo em vista as características do objeto deste estudo parece-nos que a forma mais adequada de abordagem seja a denominada por alguns autores, como Minayo, ${ }^{51}$ de qualitativa. $E$, seguindo tendência mais atual e que evita a rígida separação entre o quantitativo e o qualitativo, utilizamos o termo abordagem Interpretativa.

Essa opção metodológica leva em conta a diferenciação das pesquisas por meio de duas abordagens denominadas confirmatórias. Aquelas em que o pesquisador tem uma hipótese para testar, comparar e analisar, utilizando métodos estatísticos sofisticados, afim de obter resultados mais precisos sobre aceitação ou rejeição. $E$ as que utilizam a abordagem interpretativa, segundo a qual, a partir de pressupostos teóricos, sobre as impressões da vivência, elabora-se o desenho da pesquisa, isto é, as experiências de pessoas são organizadas de forma que seja possivel analisar e interpretar determinados segmentos do real.

Para definir este tipo de abordagem baseamo-nos no proposto por Anderson e Burns ${ }^{1}$, que consideram dois universos amplos de pesquisa, trabalhando com metodologia e técnicas bastante diferentes. Ainda, para esses autores, a coexistência de ambas contribui, cada uma a seu modo, para a interpretação mais completa do fenômeno. ${ }^{58}$

Para Anderson e Burns, ${ }^{1}$ as pesquisas interpretativas baseiam-se tanto no racionalismo alemão (Leibniz, Wolf e Kant), como na Fenomenologia de E. Russel, na Sociologia de Max Weber, como na Ciência Humana de W. Delthey. Podem ser 
definidas como:

"Uma grande forma estrutural deste modo de pesquisar é a obrigação de entender o fenômeno social humano partindo de uma perspectiva pessoal. Como as pessoas interpretam e definem o mundo. O significado subjetivo das ações humanas é o conteúdo legítimo dos estudos". (Anderson e Burns, ${ }^{1}$ pág. .5)

A pesquisa assume um ponto de vista idealista, em que o conhecimento não é constituido na descoberta e sim criado por uma mente ativa. Há também características mais realistas do que controladas, mais qualitativas que quantitativas, mais subjetivas que objetivas e racionais, preocupando-se empiricamente mais com o contexto do que com a repetição da experiência. Utiliza ainda conceitos concretizantes e sensibilizantes, assim definidos pelos autores: ${ }^{1}$

"Conceitos concretizantes identificam e ilustram significados apontando para símbolos especiais na cultura ou no grupo em que estão sendo estudados, em vez de definir conceitos mostrando como são medidos. Conceitos sensibilizantes, termo de autoria de Herbert Blumer, ao referir-se aos conceitos que dão um sentido de referência ou orientação geral de um fenômeno, em vez de uma definição precisa".

(Anderson e Burns', pág.: 6)

Como vimos, este tipo de pesquisa possui caráter mais descritivo que a confirmatória, tanto por que um de seus objetivos é a compreensão total de uma dada perspectiva e o significado das ações e eventos sob estudo. e "... também pelo fato de que as palavras são a forma prioritária dos dados". ${ }^{01}$ 


\section{V-5- POPULAÇÃO ESTUDADA}

Optamos por trabalhar com os profissionais com atuação direta no atendimento aos usuários, considerando que a vinculação dos profissionais ao Serviço dá-se a partir de sua inserção em uma categoria funcional. Assim chamamos os com formação universitária: coordenadores (responsáveis pela gerência), docentes dos diversos cursos (Ciências Farmacêuticas, Enfermagem, Fisioterapia, Fonoaudiologia, Medicina, Nutrição, Psicologia e Terapia Ocupacional), médicos assistenciais, enfermeiros e dentistas e os com formação no nível médio: técnicos e auxiliares de enfermagem e de saúde, auxiliares e técnicos em odontologia, com atuação nos três periodos de atendimento. Dentro desta explanação, procuramos distinguir os sujeitos, tanto pela profissão como pelo nivel de escolaridade, dadas as diferentes inserções sociais dos profissionais, fatores determinantes de suas escolhas e respectivas trajetórias. Norteamo-nos, também, pelo princípio de que um tipo estabelecido de concepção permeia a prática profissional. Além disso, como as práticas dos profissionais de nível médio na área de enfermagem e da saúde bucal são diversas, essas foram consideradas em grupos separados. No total tivemos sete grupos: docentes, médicos, enfermeiros, dentistas e coordenadores, (profissionais com curso superior), técnicos e auxiliares de enfermagem, técnicos em higiene bucal e auxiliares de consultório dentário (profissionais de nível médio).

Para a seleção dos entrevistados, partindo da totalidade dos profissionais, recorremos à amostragem qualitativa, em que foi garantida a representatividade de todos os profissionais, utilizando os seguintes procedimentos: ${ }^{16}$ 
Consideramos primeiramente a totalidade dos profissionais envolvidos no trabalho docente - assistencial do CS, de acordo com sua inserção nos sete grupos. Procuramos, ainda, adotar critério que permitisse que todos os tipos de pensamento (representação) fossem contemplados, preocupando-nos com os aspectos relativos à fidedignidade e validade dos dados. De acordo com Spink ${ }_{1}^{72}$ fidedignidade retrata a possibilidade de obtenção dos mesmos dados em circunstâncias diversas, ou com utilização de técnicas diversas de coleta de dados.

Durante o periodo da pesquisa, atuavam no Serviço 69 profissionais, considerados como universo de investigação, assim distribuídos: Dois coordenadores (um deles da Prefeitura Municipal, também docente de medicina, e outro docente, da faculdade de enfermagem, responsável pela PUC). Dezenove docentes, sendo sete do curso de medicina, três da faculdade de enfermagem, dois do curso de psicologia, e um docente de cada um dos seguintes cursos: fonoaudiologia, nutrição, farmácia, fisioterapia e terapia ocupacional. Médicos assistenciais, havia onze, sendo três pediatras, três clínicos gerais, três ginecologistas e dois psiquiatras, cinco dentistas e três enfermeiros. A equipe de nivel médio era composta por duas técnicas e quinze auxiliares de enfermagem, seis auxiliares de saúde em capacitação para auxiliares de enfermagem, uma técnica em higiene bucal e cinco auxiliares de consultório dentário.

A partir da totalidade dos elementos que compunham cada um dos grupos (docentes, médicos, dentistas, enfermeiros, coordenadores, profissionais de nivel médio das áreas de enfermagem e odontologia), compuseram a amostra os dois coordenadores, dadas as peculiaridades de suas funções, oito docentes, sendo um de cada curso (exceto medicina, em que atuavam sete docentes, o que fez com que houvesse opção por dois deles), quatro médicos, um de cada especialidade, dois 
dentistas, duas enfermeiras, uma auxiliar de consultório odontológico e uma técnica de cirurgião dentista, duas técnicas e cinco auxiliares de enfermagem, perfazendo um total de 27 profissionais.

Para a seleção do profissional a ser entrevistado, em cada segmento, utilizamos técnica de sorteio, seguindo os princípios da amostra casual simples sem reposição, em todos os casos em que havia mais de um elemento. No caso dos docentes de medicina foi excluído do sorteio o coordenador da Prefeitura Municipal (pela função administrativa), também docente; dentre os de enfermagem foram excluídas a coordenadora do serviço (docente) e a autora deste estudo. Com relação às enfermeiras, optamos por entrevistar uma delas, com vínculo há mais tempo no CS e uma das outras contratadas há menos tempo (cerca de dois meses). Como as auxiliares trabalham em sistema de rodízio pelas diversas áreas de atendimento, realizamos o sorteio de acordo com a escala de atividades. Assim, entre as em atividade em uma dada área, foi sorteada uma. Procedemos desta maneira porque as atividades cotidianas diferem em cada área, e as qualidades e deficiências do Serviço, relacionadas às vivências cotidianas, também foram objeto de análise. As áreas são: recepção, atendimento ao adulto, mulher e criança, imunização e atendimentos gerais: inalação, curativos e esterilização). 


\section{V-6- COLETA DE DADOS}

\section{As Entrevistas}

As entrevistas tiveram caráter não-diretivo, sendo utilizado um roteiro contendo temas de maior interesse para a investigação (anexo 3). Como forma de elaborarmos o roteiro definitivo realizamos, previamente, duas entrevistas-padrão com uma auxiliar e uma enfermeira, ambas com atuação no Centro de Saúde Dr. Pedro de Aquino, onde também se dão atividades de docência e assistência. $\mathrm{Na}$ ocasião, verificamos a pertinência das temáticas, a compreensão das entrevistadas e o tempo de duração das entrevistas. Além disso, a pesquisadora pode sentir qual a melhor forma de condução da conversa.

Cumprida esta etapa, as entrevistas foram realizadas pela própria pesquisadora no Centro de Saúde, ou em local de preferência dos entrevistados, caso da maior parte dos docentes, ocorrendo, após concordância dos sujeitos, em data pré-agendada de acordo com as conveniências dos entrevistados, cabendonos esclarecer que, em periodo anterior, apresentamos o projeto da pesquisa aos coordenadores do CS, solicitando autorização prévia para realizarmos a investigação e pedindo a eles que informassem o grupo de docentes e de profissionais assistenciais sobre a realização do estudo. Após esta etapa entregamos uma carta de esclarecimento e agradecimento aos colaboradores (anexo 2). Todas as entrevistas foram realizadas durante os meses de abril e maio de 1996 
Parece - nos oportuno colocar que os entrevistados mostraram-se bastante disponiveis e abertos ao diálogo, sem se intimidar diante das colocações da entrevistadora, pelo contrário, revelando postura solícita e preocupando-se em atender ao propósito do trabalho, o que constituiu uma experiência profissional muito rica. O tempo expendido em cada entrevista variou entre 40 e 90 minutos, o que aconteceu dadas as características diversas dos entrevistados. Observamos, ainda que as conversas com os docentes e coordenadores foram as mais longas. As entrevistas tiveram seus registros gravados após anuência dos entrevistados.

A transcrição das gravações foi realizada pela pesquisadora e por duas auxiliares de pesquisa (alunas do Curso de Enfermagem em programa de iniciação cientifica). Após a transcrição a pesquisadora realizou nova audição de todas as fitas para revisão do conteúdo e melhor compreensão do sentido das falas. Manteve-se os diálogos originais, respeitando as pausas, interjeições, risos e outras manifestações. Posteriormente, agrupamos todo o material de acordo com as temáticas da entrevista e com o segmento profissional dos entrevistados, havendo digitação para conformação do banco de dados que perfaz o total de 210 laudas.

\section{Análise dos Dados}

Após conformação do banco de dados, procuramos reler e ouvir as gravações individuais para compreensão do tom das entrevistas e a articulação do que fora dito em cada abordagem temática. Posteriormente foi feita uma leitura de cada tópico da entrevista, nos grupos de profissionais para apreensão e interpretação do sentido das falas, ou seja, do seu significado. Ai obtivemos as 
categorias empíricas de análise, a partir da classificação e agregação dos dados. Para buscar o significado das falas utilizamos as sugestões metodológicas da análise temática, meio auxiliar para apreensão do conteúdo das representações, efetuando análise denominada, por Brito, ${ }^{07}$ como "não lingüística". Assim:

"O discurso seria a expressão das concepções, valores e interesses do grupo social que o emite. Não há, por isso mesmo, preocupação de se delimitar a extensão ou definir-se a natureza do discurso, ou ainda, de se identificar os recursos expressivos de que dispõe o locutor e estabelecerem-se as relações que se constróem entre o locutor e o interlocutor...". (Brito, ${ }^{07}$ pág.: 81)

Deste modo, os locutores podem ser identificados por meio de critérios denominados por Brito ${ }^{07}$ como sociológicos, tais como classe social e profissão. Por exemplo:

"O discurso como expressão ou produto de classe, ao mesmo tempo em que é caracterizado a partir daí, permite a compreensão dos movimentos e das posições que este produtor tem no tecido social (...). Em segundo lugar, observe-se que a significação do discurso é autônoma, isto é ela traz um conteúdo próprio e claramente identificável. Daí porque mais que a forma é ao que ele remete que interessa." (Pág.:81)

Como dissemos anteriormente, a análise dos dados foi realizada com vistas à apreensão e interpretação dos sentidos contidos nas falas dos sujeitos. De acordo com Conerth, ${ }^{17}$ a compreensão lingüística depende do entendimento do outro, tendo então um sentido "dialogal", visto que as palavras são relativas às coisas, em nosso caso, questões relativas às vivências profissionais dos sujeitos no CS. Portanto, pela compreensão dos enunciados, chega-se à compreensão das coisas, sendo 
importante definirmos o que se entende por compreensão. Nesse sentido, para o autor:

"Compreender" significa (...) imediatez da visão da inteligência que apreende um sentido. "Interpretar", ao contrário, quer dizer a mediação pelo conhecimento racional, que pressupõe a imediatez da compreensão prévia, medindo-a pela decomposição, fundamentação e explicação e elevando-a à imediatez mediata de uma compreensão aprofundada e expressamente desenvolvida."

$$
\text { (Conerth, }{ }^{17} \text {, pág.: 48) }
$$

Bakhtin $^{02}$ comenta que a análise temática pressupõe a busca do sentido da enunciação, definindo o tema como o sentido, a significação:

"O tema da enunciação é determinado não só pelas formas lingüísticas que entram na composição (as palavras, as formas morfológicas ou sintáticas, os sons, as interações), mas igualmente pelos elementos não verbais da situação"

(Pág.: 128)

De acordo com Minayo ${ }^{51}$, nas análises temáticas o pesquisador se encaminha, seja pela repetição e contagem da freqüência do tema, seja pela busca dos valores de referência e modelos de comportamento presentes no discurso, forma por nós utilizada no presente trabalho.

Cabe ressaltarmos que a extensão e a riqueza do conteúdo do material empírico determinaram sua subdivisão e o agrupamento em três grandes eixos assim denominados:

Trajetórias Profissionais - Primeiro Eixo: Relativo às questōes individuais, em que foram enfocadas as trajetórias profissionais dos entrevistados e as motivações para escolha do Serviço, o que pode ser conseqüência de acasos, e determinações próprias. Como meio de compreendermos as implicações das trajetórias dos profissionais nas representações das finalidades e práticas do CS. 
Cabe ressaltarmos que, este primeiro eixo, também funcionou como forma de aproximação dos sujeitos e das suas principais características.

O Centro de Saúde e o SUS - Segundo Eixo: Relativo às opiniões sobre as finalidades do Serviço, conhecimento do significado do SUS e opinião sobre o funcionamento do Sistema e Serviço de Saúde utilizado em caso de necessidade pessoal ou familiar onde buscamos apreender as representações acerca da natureza e das finalidades do Serviço.

Aproximação das práticas - Terceiro Eixo: Relativo à opinião sobre as qualidades e deficiências do Serviço como forma de acessar as representações relativas às práticas profissionais.

Para efetuarmos a análise em cada eixo distinguimos os diferentes segmentos profissionais: docentes, médicos, dentistas, enfermeiros e coordenadores (profissionais com formação em $3^{\circ} \mathrm{grau}$ ) e de nível médio, auxiliares de enfermagem e de odontologia. Fizemos tal opção, durante o momento de análise dos dados relativos às escolhas ou à trajetória dos profissionais do CS, ocasião em que verificamos que a melhor forma seria agrupar as falas dos profissionais universitários. Estes tiveram suas expressōes derivadas da oportunidade de escolha de uma profissão. Em contraposição, os de nível médio se profissionalizaram, na maior parte, em decorrência da oportunidade de trabalho e emprego. Consideramos ainda que a natureza das atividades docentes ou assistenciais conferia uma particularidade aos profissionais de nivel superior.

As questões de cada eixo foram tratadas individualmente e, a partir do seu conteúdo, foram formadas as categoria empíricas de análise para cada um dos grupos profissionais. Utilizamos ainda, categorias teóricas da teoria da reforma 
sanitária e do SUS, tais como: cidadania, eqüidade, e integralidade da atenção à Saúde. 


\section{VI- Resultados}

\section{VI-1- Trajetórias Profissionais - Primeiro Eixo}

\section{Considerações Iniciais}

Das entrevistas e das falas dos profissionais com formação universitária e das dos de nivel médio, tentamos resgatar parte de suas história, procurando ser fiéis a ela. Nela, podemos observar que as pessoas são inseparáveis das condições sociais de suas existências. Vemos, também, que as trajetórias pessoais muitas vezes são capazes de explicar as representações contidas nas falas atuais, embora não haja entre elas relação de causa e efeito. 


\section{Profissionais de Nível Superior}

Com relação à opção profissional, sabemos que a organização da sociedade brasileira faz com que uns poucos, filhos das classes com maior poder aquisitivo, cursem a Universidade, caminho quase natural para a maioria, como nascer e estudar do primeiro ao terceiro graus, de forma contínua. Assim, a profissionalização dá-se depois do curso superior quando, em decorrência do próprio sistema de ensino brasileiro, se inicia por volta dos 18 anos, ou seja, no auge das transformações adolescentes. Deste modo, os então profissionais, quando instados a falar sobre suas trajetórias profissionais, têm uma análise já elaborada dos motivos de ingresso na Universidade. Todos fizeram, durante o momento da entrevista, uma releitura das motivações dos adolescentes para a escolha da profissão. Motivações diversas, às vezes mais sentimentais que racionais. Nas entrevistas, surgiram momentos distintos, obedecendo a uma seqüência: a entrada na faculdade; a construção de uma carreira por meio da descrição de capacitações posteriores, quando alguns destacam o interesse pela Saúde Pública, o ingresso no mercado de trabalho e no Serviço.

\section{Docentes}

Oito dos docentes entrevistados possuem, em comum, o fato de terem optado por suas carreiras, bastante jovens. Apenas um deles ingressou em medicina mais tardiamente, depois de cursar engenharia por algum tempo e ter 
vivenciado experiências em cursos abertos no exterior, na área das ciências sociais feitos. Em decorrência, interessou-se pela Saúde Pública, ingressando em medicina com a finalidade de trabalhar aí. A partir da descrição do motivo de escolha do curso podemos identificar as seguintes categorias empíricas de análise:

Influência de alguma pessoa da familia, aí incluidos aqueles cuja escolha foi decorrente de um contato prévio e geral com o fazer dos profissionais destas áreas, seja acompanhando pessoas da familia, seja por aconselhamento de parentes que observaram suas tendências e gostos pessoais.

Exemplo deste tipo de motivação é dado pela professora de farmácia que iniciou o curso por aconselhamento paterno, e por um gosto particular pela química. Já na faculdade, percebeu um grande interesse pela questão dos medicamentos, seu uso e políticas sociais relacionadas, afastando-se da quimica. Já a professora de enfermagem gostava da profissão da irmã mais velha (enfermeira de Saúde Pública). Outro caso é o do professor de fisioterapia que tomou contato com a profissão quando seu avô necessitou dos cuidados de um fisioterapeuta. No vestibular, esteve entre a opção pela agronomia ou pela fisioterapia (ambas da área das ciências biológicas).

Querer trabalhar com pessoas ou ajudá-las, neste caso, a escolha é explicada por um sentimento humanitário, decorrente também de um conhecimento geral do fazer profissional, quando o aspecto predominante absorvido é o das relaçōes humanas, principalmente a relação de ajuda.

Assim, um dos docentes de medicina (2), cujo contato com a profissão deuse por meio da mãe, visitadora sanitária da Fundação CESP, disse que, na ocasião da escolha, experimentava sentimentos de solidariedade. O outro docente de 
medicina (1), o que iniciou o curso mais tarde, comenta o desejo original de trabalhar com Saúde Pública, por experimentar sentimentos parecidos.

A professora de psicologia, com a mesma motivação, elaborou durante a entrevista, uma explicação psicologizada para a escolha, justificando que entrou no curso buscando uma forma de compreender-se (donde se intui que o curso representava para ela uma possibilidade de compreender o outro). Expressou-se assim:

"Então foi uma escolha que nitidamente hoje eu percebo que eu tava buscando era um conhecimento meu próprio, de mim mesma, né?"(Docente de psicologia)

Temos também a professora de terapia ocupacional, que ingressou primeiramente em fonoaudiologia, em evidência ao final da década de 70 , para trabalhar com pessoas, mudando de curso por maior identificação com o trabalho desenvolvido pelos profissionais de terapia ocupacional.

Busca por uma profissão nova, categoria na qual se incluem pessoas que buscavam uma atividade diferente das conhecidas.Com essa opção temos as professoras de fonoaudiologia e de nutrição, que também sentiam maior identificação com a área da Saúde:

"A escolha pelo curso de nutrição foi uma coisa muito casual que nem um tiro no escuro... Essa coisa de você entrar na faculdade muito nova... eu acho que não diferente da maioria dos estudantes... Muito sem consistência, sem nehuma consistência. Aliás eu tinha uma afinidade pela área da Saúde... Achava que nutrição, lidar com alimentos, um curso novo, então vamos ver o que é..."(Docente de nutrição)

Prosseguindo na descrição de suas trajetórias observamos que, nos discursos de seis dos docentes figura o Interesse pela Saúde Pública, como um 
campo do saber pelo qual manifestaram interesse e dirigiram suas buscas de aperfeiçoamento profissional. Tal ocorreu com quatro deles, já na graduação, ou antes dela (caso dos dois docentes de medicina, da de nutrição e com a de enfermagem), e também com duas depois do ingresso na PUC (farmácia e terapia ocupacional). Nesta ocasião aliaram seus interesse pessoais às necessidades dos departamentos e disciplinas em que estavam inseridas. O interesse pela Saúde Pública para eles significa o encontro de um novo caminho, ou de respostas pessoais/profissionais. Um dos docentes (medicina 2), faz o seguinte comentário:

"Agora, quando cheguei na faculdade, porque eu tive contato com a Saúde Preventiva, e foi ai uma guinada grande, porque eu estava imaginando ser aquele medicão (o médico tradicional), né?... E aí foi essa coisa que me levou a ficar, e foi aonde achei algumas respostas, digamos assim." (Docente de medicina 2)

Presente em sua fala, a concepção de que os interessados pela Saúde Pública caracterizam-se por uma diferença com relação aos outros ou, talvez, como out siders, com visão própria e mais ampla. Essa concepção, de forma mais ou menos explícita, ancora as falas de alguns dos docentes e está presente, também, no discurso da docente de nutrição que, inicialmente, não gostou do curso. Pensou, inclusive, em desistir, quando ainda na graduação descobriu seu interesse pela Saúde Pública:

"Acabei terminando o curso, assim num grau de insatisfação muito grande, é aí que eu começo a me interessar pela Saúde Pública, ainda na graduação." (Docente de Nutrição)

Parece que, dentro da pequenez das ações propostas, apenas pelo exercício técnico da profissão, a Saúde Pública, campo do interdisciplinar, no qual estão 
imbricadas as ciências sociais e humanas, oferecia alternativas mais amplas de atuação.

Nos docentes de fisioterapia, psicologia e fonoaudiologia vemos que o interesse pelo trabalho com a Saúde Pública deu-se em decorrência dos projetos pedagógicos de seus cursos que abriam novos campos de estágio profissionalizante.

Supúnhamos, quando da elaboração desse estudo, que os profissionais com formação para o exercício na Saúde Pública teriam um dominio maior dos princípios norteadores da reforma sanitária e do SUS. Além disso, pudemos observar, por meio da análise de suas trajetórias, que sua inserção na Saúde Pública levou-os a uma opção pelo trabalho na área enquanto profissionais. Assim, se tivessem prática unicamente assistencial, estariam inseridos no campo.

Também parece-nos importante destacar que a maior parte dos professores, exceto os docentes substitutos e as de fonoaudiologia e nutrição, não descreve os motivos de ingresso na docência, centrando suas falas na profissão de origem e na Saúde Pública. Vêem-se primeiramente como profissionais, depois como professores. Assim, estão professores, porque são profissionais. Com relação às suas carreiras acadêmicas, a professora de fonoaudiologia fez doutorado em sua área; um dos docentes de medicina (2) cursava mestrado em Saúde Púbica; a de nutrição em Sociologia, os de farmácia e medicina (1), em Educação.

Com relação aos vinculos de todos os docentes com a Universidade, apenas dois deles estavam em caráter temporário (um no Departamento de Medicina Social e Preventiva (docente de medicina. 2), e outro, no Departamento de Enfermagem de Saúde Pública e Mental. Os demais eram professores do quadro docente dos diversos cursos, há longo período. Em decorrência, reviveram em suas falas os 
muitos momentos das trajetórias na Universidade e as inúmeras vivências para a construção e consolidação do Projeto Pedagógico iniciado na década de 80 , e implementado nos diversos cursos e unidades, a partir de então.

Pelas falas vemos que o ingresso da maior parte dos docentes no CS Integração não teve caráter gratuito, mas foi conseqüência das reformulações curriculares dos próprios cursos, embasadas em projetos pedagógicos que visavam atender aos principios de abertura da Universidade para a sociedade. Tratava-se de um projeto de transformação da realidade social e que repercutiu de forma geral no ensino e nos projetos de extensão.

\section{O Ingresso no Centro de Saúde Integração}

Todos os docentes atuam no Serviço em decorrência dos Projetos Pedagógicos dos cursos em que trabalham, designados para atender às necessidades dos departamentos e disciplinas. De acordo com Martins, ${ }^{42}$ além dos cursos de enfermagem e medicina que já atuavam no CS da Vila Castelo Branco desde 1980 , os primeiros a aderirem ao projeto foram os cursos de fisioterapia e terapia ocupacional. Os de farmácia e nutrição ingressaram mais tardiamente, com um projeto de atuação que se dava nos quatro serviços da Universidade. Para a autora, $^{42}$ o ingresso desses cursos no projeto teve grande relação com a movimentação que acontecia na Saúde Pública e como decorrência do projeto de reforma sanitária. Já a adesão do curso de psicologia (1986), teve mais o caráter de ampliação do campo de atuação do psicólogo. Cabe ressaltarmos que os cursos de psicologia e fonoaudiologia mantêm clínicas vinculadas ao instituto. Embora fonoaudiologia pertença ao mesmo instituto que psicologia, a adesão ao projeto de 
atuação nos CS foi mais tardia. Inicialmente ocorreu por meio de proposta individual de uma docente para a Carreira Docente e, posteriormente, pela disciplina Fonoaudiologia Preventiva II, cujo enfoque é, essencialmente, realizar ações educativas e preventivas, por meio de projetos de atuação. ${ }^{42}$

Para melhor compreensão da questão trazemos o seguinte trecho extraído de Martins: ${ }^{42}$

"Para os cursos de Psicologia e Fonoaudiologia essas questões, ou seja, a questão do SUS e da Reforma Sanitária, não estavam tão presentes; não eram objeto de preocupação para a formação dos alunos. O desenvolvimento de uma proposta pedagógica em uma unidade básica parece-nos tratar-se da possibilidade de inserção do profissional em outros espaços, que não aqueles restritos ao atendimento clínico, bem como proporcionar ao acadêmico a vivência em um serviço de caráter público, com uma dinâmica própria e com uma diversidade de profissionais". (Pág.: 74)

Em nossa entrevista, a professora de fonoaudiologia enfatiza que seu ingresso aconteceu quando buscava campo de estágio para que o curso, de acordo com a reformulação curricular, pudesse enfocar outros aspectos que não só a clínica, e por conhecer a então coordenadora administrativa do Serviço, denotando desconhecer as propostas da Universidade para a rede básica.

\section{Médicos}

Das falas dos médicos pudemos apreender duas categorias: Interesse por trabalhar com pessoas e curá-las - Não saber o motivo da escolha, a primeira delas já descrita quando da análise das opçōes dos docentes e ora relatada por meio dos seguintes exemplos: Um dos médicos (clínico) revela que ao terminar o 
curso colegial interessou-se por estudar ciências humanas, e encarando a medicina como tal, optou por esta profissão. Comenta ainda que escolneu como especialidade a clínica médica por concordar com a filosofia desse tipo de atuação, cuja visão preliminar, segundo ele, é a do sujeito como um todo. A pediatra, inicialmente, tinha vontade de curar pessoas. Relata que tal sentimento pode ser decorrência de sofrimento pessoal ao perder um irmão com hidrocefalia, e tê-lo visto sofrer sem obter cura.

Dois dos profissionais, o ginecologista e a psiquiatra relataram que o desejo de cursar medicina esteve presente em suas vidas desde a infância, não sabendo explicar o porquê do mesmo. Curiosamente, o ginecologista relata que o pai, mecânico, tinha clientes médicos e conhecendo seu desejo, levaram-no a hospitais, o que fez com que ele confirmasse sua opção inicial.

Todos fizeram residência na área de atuação e o clínico, também docente da PUCCAMP, cursou especialização em Saúde Pública.

Os profissionais da área, exceto a psiquiatra, tinham exercício liberal e trabalho assalariado em outros locais que não o Centro de Saúde. Subjaz a suas falas que o ingresso na Rede Básica Municipal, por meio de concurso público, deveu-se à oportunidade de trabalho.

O clínico, que também é docente do curso de medicina, comenta:

"Quase trabalhei em tempo integral na PUC, mas por uma série de circunstâncias, até o mercado de trabalho te obriga a ter mais que um emprego...E acabei optando por fazer uma medicina no CS" (Clínico) 


\section{O Ingresso no Centro de Saúde Integração}

Com relação à escolha do CS Integração, vimos que o fator preponderante foi a proximidade do Serviço da Universidade (PUC), e do Hospital, além das facilidades trazidas por essa aproximação (os quatro têm e tinham, por ocasião da escolha, um vínculo com a PUCCAMP).

Para nós fica a impressão de que essa proximidade não é apenas física, tendo em vista que outros fatores apontados foram a maior qualificação do Serviço, decorrente do trabalho docente e do quadro multiprofissional, dos equipamentos e também do funcionamento do CS em três turnos, o que permite maior flexibilidade nos horários de trabalho. Estes fatores funcionaram como estímulo para a escolha. Um dos médicos relata ter ingressado na rede em 1986, em outro CS e, em busca de melhores condições técnicas de trabalho, solicitou transferência para o Integração:

Assim:

"Um posto de Saúde de complexidade maior, pode te oferecer retorno em termos de trabalho. Então você trabalha no Serviço maior... Pode ter integração com outras áreas, ter opção de turnos de trabalho diferentes, então existe maior mobilidade para você se adaptar... O fato de ser Posto de Saúde em que a PUC atua também, então teria a possibilidade de compensar todo aquele desgaste que você fica no posto de Saúde periférico...". (Clínico)

Com o ginecologista aconteceu fenômeno semelhante para a determinação do pedido de transferência. A pediatra comenta ter sido aprovada em $1^{\circ}$ lugar no concurso para ingresso. Portanto, houve várias opções de escolha, preferindo 0 Serviço tanto pela proximidade do Hospital, onde terminava residência, como pelo 
fato de estar vinculado à PUCCAMP. Já a psiquiatra enfatiza ter havido poucas opções em seu momento de escolha (decorrentes da classificação no concurso, por falta de experiência na área de Psiquiatria, segunda residência) e que, dentre as alternativas, optou pelo Integração, em virtude da proximidade do hospital em que terminava residência.

Das falas dos profissionais pudemos apreender que o vínculo Serviço-PUC tende a qualificar o CS, também pelas inserções dos médicos na Universidade e pela possibilidade de trabalho em equipe multiprofissional. De acordo com os médicos, os recursos tecnológicos mais qualificados permitem, além da possibilidade de prestar melhor assistência, espaço de aprendizado e discussão.

\section{Dentistas}

Nas falas de uma das dentistas sobre a opção profissional, encontramos a categoria, também presente para alguns docentes, Identificação com o fazer do dentista, o que ocorreu porque teve necessidade de tratamento ortodôntico na adolescência, e gostou do trabalho de seu dentista. A outra profissional, por experiência pessoal, acreditava que, A profissão de dentista conferia prosperidade, e em decorrência, ao exercer a profissão poderia ter acesso a uma forma de viver diferenciada da de sua família. Explicando o motivo de sua opção relatou que, na pequena cidade onde vivia, o dentista era a única pessoa próspera. Riu muito ao fazer esse comentário: 
"Vivia numa familia assim de mineiros do interior, e essa familia tinha muitas terras... Havia aquele valor do apego às terras, mas não o lado do conforto.... Eu não via sinal de prosperidade dentro do meu núcleo familiar". ... E tinha um dentista nessa cidade que era a única pessoa que eu considerava próspera. Então ele tinha televisão, a primeira televisão da cidade foi dele, o primeiro carro...Minha escolha profissional não foi baseada em vocação..."

(Dentista 2)

\section{O Ingresso no Centro de Saúde Integração}

Da mesma forma que, para os médicos, a opção por atuar em Centro de Saúde deveu-se à necessidade de trabalho assalariado, uma delas (dentista 1) diz ter levado em conta a oscilação da demanda de clientes em seu consultório.

Com relação à escolha do CS Integração, o motivo foi, dentre os possiveis, o fato de ser o mais próximo de seus locais de residência, e de fácil acesso.

\section{Enfermeiras}

Da fala de uma das enfermeiras, sobre os motivos da opçāo profissional, obtivemos a categoria, Influência familiar, que já foi identificada entre os docentes. A profissional (enfermeira 1) revela haver em sua familia muitas pessoas que trabalhavam na área da Saúde e que a convenceram a optar pela enfermagem. Ressalta que, na ocasião, tinha maior interesse por arquitetura ou profissão afim e que, após o ingresso, identificou-se com o curso. 
Outra categoria obtida foi: Afinidade pela área da Saúde, a enfermeira 2 ingressou em enfermagem por segunda opção (a primeira era odontologia), fato bastante comum em inúmeras Universidades, e que em princípio denota o menor prestígio social da profissão (curso).

Com relação às atividades e capacitações posteriores à graduação, a primeira delas fez habilitação em obstetrícia e, posteriormente, atuou nos hospitais da PUCCAMP e da UNICAMP, em centro cirúrgico. A segunda enfermeira veio de Minas para Campinas, ingressando no Hospital das Clínicas da UNICAMP no setor de assistência a recém nascidos, ambas, portanto sem experiência de atuação na rede de CS.

\section{O Ingresso no Centro de Saúde Integração}

As duas profissionais ingressaram no Serviço, por concurso, e optaram por exercer trabalho fora do hospital. A primeira delas (enfermeira 1), conta ter prestado concurso para a rede por acaso, ou seja, "Por prestar, porque era um concurso", quando aprovada vivia muitas dificuldades familiares (doença paterna), e resolveu trabalhar exclusivamente na rede. Na ocasião, pensava que não iria gostar de Saúde Pública tendo em vista, que:

"Trabalhar com população muito carente, achei que não ia conseguir. Entrei para conhecer, porque eu só conhecia a área hospitalar, não a área de Saúde Pública, e daí eu entrei e fiquei até hoje porque eu gostei."(Enfermeira 
A outra profissional comenta que, desde a faculdade, desejava trabalhar fora do hospital, tendo prestado concurso na rede por essa razão. Descrevendo sua trajetória comenta que, após a graduação, trabalhou em Minas Gerais, e resolveu procurar um centro maior, em busca de qualificação:

"Ai eu vim para a Unicamp, para trabalhar, aprender e para eu depois ver o que iria fazer. Ai prestei concurso, porque eu, apesar de adorar neo, eu queria sair do hospital (pausa breve). Aí eu prestei concurso para a Saúde Pública... Ai eu vim porque eu queria sair do hospital. E eu sempre gostei, na época da faculdade, de Saúde Pública, só que eu não tinha experiência e o que a gente vê na faculdade é muito pouco."(Enfermeira 2)

Sabemos que os enfermeiros têm o trabalho assalariado como a principal alternativa de inserção no mercado, seja nas instituições hospitalares, nas quais há trabalho em turnos e fins de semanas, seja em serviços ambulatoriais, cuja maior oferta de empregos dá-se nos CS. São locais em que, usualmente, não há trabalho em fins de semana, por exemplo. Essa reflexão e as falas das próprias profissionais nos levam a concluir que o que subjaz à opção por trabalhar no Serviço são as condições do trabalho em CS, talvez por ser menos exaustivo, em periodo diurno e durante a semana, mesmo porque uma das enfermeiras expressa não ter sentido afinidade inicial pelo campo da Saúde Pública. Por outro lado, a outra profissional coloca que a experiência obtida na graduação, embora pequena, reforçou seu interesse.

Para a opção das enfermeiras pelo Centro de Saúde Integração, o fator preponderante foi a proximidade da PUC. Uma delas, por querer aperfeiçoar-se e estar próxima da Faculdade-Universidade; a outra, que não conhecia a rede, obteve indicação de colegas de trabalho que cursaram a Universidade ("um bom Serviço"). Assim: 
"Perto da PUC, eu pretendia continuar estudando... Então eu queria um local próximo..." (Enfermeira 1)

Ou,

"Não conheço essa cidade e eu tinha colegas que fizeram PUC e estágio aqui. E aí, no dia da escolha, eu perguntei: Qual é esse? Qual você acha que eu devo ir? Ah vai nesse que eu fiz estágio lá na PUC e era bom..."

(Enfermeira 2)

É interessante observarmos que, as enfermeiras e os médicos reforçam que a idéia de que sua escolha pelo CS deveu-se, de um ou outro modo, ao vínculo Serviço- PUC. Já os dentistas não fizeram essa consideração, o que talvez se deva à não inserção da Faculdade de Odontologia da PUC nos serviços básicos, por opção pedagógica.

\section{Coordenadores}

Tanto a coordenadora acadêmica quanto o coordenador da Prefeitura Municipal (administrativo) escolheram a profissão por motivos semelhantes, ou seja: Afinidade pela área da Saúde e experiência anterior com Saúde no $2^{\circ}$ grau.

"Bom a minha escolha profissional para a área da Saúde Pública, eu acho assim, eu fiz o técnico de enfermagem, então tinha experiência vivida ... E a área da Saúde Pública me parecia um espaço assim, onde o enfermeiro tinha um pouco mais de autonomia para desenvolver seu trabalho, mais independência, principalmente da figura do médico, não é?" (Coordenadora acadêmica)

Já o coordenador administrativo: 
"Desde pequeno eu gostava da área médica e, na cidade em que morava não tinha nada nessa área, e quando fui fazer o colegial fiz técnico em veterinária (Defesa Sanitária Animal)".(Coordenador administrativo)

Na ocasião, esse curso the pareceu o mais próximo da área que desejava. Faz questão de relatar que, durante o curso de medicina, foi liderança estudantil, dado seu interesse pelas questões políticas. Nesse periodo, por viajar muito, conhecera Campinas e a proposta da cidade para a Saúde Pública, achando-a interessante e se fixando nela como médico da Prefeitura (clínico).

Os dois coordenadores, de forma semelhante a alguns docentes, destacam seu interesse e predisponibilidade para o trabalho com Saúde Pública já na graduação, dedicando à área seus investimentos posteriores. A coordenadora acadêmica possui curso de Habilitação e Especialização em Saúde Pública, mestrado em Educação e dissertação sobre Interdisciplinaridade no CS. Já o coordenador administrativo cursou residência em medicina preventiva e especialização em gerenciamento (Curso Gerus). A Coordenadora Acadêmica faz o seguinte comentário sobre a Saúde Pública:

"Era uma área... Não, é uma área, que possibilita o trabalho em equipe, com outros profissionais. Então é uma área em que a pessoa fica menos bitolada, do que aquela vivência hospitalar, que tem a figura do médico e do enfermeiro..." (Coordenadora acadêmica)

Parece que, como para grande parte dos docentes o encontro da Saúde Pública, para ambos, tem conotação de opção de vida. No caso do coordenador administrativo, conseqüência da vivência política; para a acadêmica, uma outra via, que possibilita maiores vôos, representados pela possibilidade de convívio 
interdisciplinar, além das amarras mais soltas que as que são dadas pela rigidez da instituição hospitalar, comentada por nós anteriormente.

\section{O Ingresso no Centro de Saúde Integração}

Quanto à opção pelo Serviço, caso do coordenador administrativo, deveu-se à proximidade do centro da cidade (não tinha carro na ocasião), e à facilidade de acesso por ônibus (ingressou como clínico no CS da Vila Pe. Manoel da Nóbrega, sendo posteriormente convidado a coordenar o Serviço, quando a coordenadora afastou-se para trabalhar na Secretaria de Ação Regional). A coordenadora acadêmica, optou em decorrência do Projeto Pedagógico da faculdade (como os

outros docentes). Cabe ressaltar que o coordenador administrativo também é docente substituto no Departamento de Medicina Social e preventiva da PUCCAMP, cargo para o qual foi selecionado após convite de professores do Departamento. 


\section{Profissionais de Nível Médio}

\section{Auxiliares de Enfermagem}

Para podermos abordar as trajetórias das auxiliares de enfermagem importante se faz esclarecermos as políticas para contratação de pessoal de nível médio, de acordo com a Secretaria de Saúde, desde o final da década de 70 quando, efetivamente, os CS iniciaram suas atividades.

Trazemos essas questões à tona, principalmente porque muitas de nossas entrevistadas, no começo de suas carreiras, exerciam função de auxiliares de saúde, com inserção e papel bastante diferenciados dos atuais, e além disso, não se constituiam categoria da enfermagem.

De acordo com Smeke ${ }^{69}$ a concepção do trabalho dos auxiliares de saúde continha, por princípio, uma crítica ao papel proposto pela Medicina Comunitária Internacional para os agentes de saúde, não remunerados, dado o cunho, eminentemente assistencialista dessa proposta. Deste modo, o projeto de concepção do perfil destes profissionais remunerados, previa que eles, também membros das comunidades, fossem o elo entre os serviços e as populações de suas áreas de abrangência, proposta que trazia embutida a necessidade de que, a priori, os auxiliares possuíssem qualidades inerentes a uma maior consciência social e um vínculo com o movimento popular. Assim, um dos critérios para seleção era a participação do candidato em órgãos representativos. A inscrição para o processo seletivo era franqueada à população das áreas de abrangência dos dados CS, 
obedecidos critérios mínimos referentes à maioridade, capacidade de ler e escrever e realizar as operações matemáticas básicas.

Ao abordar o processo de seleção dos profissionais, Smeke ${ }^{69}$ refere, na ocasião, foi criada pela Secretaria Municipal de Saúde, a "Comissão de Seleção, Treinamento e Reciclagem", a quem cabia tais responsabilidades, constituida por nove profissionais das várias categorias, eleitos por seus pares e que costumava rechaçar pedidos de políticos e afins para provimento dos cargos.

Dada a forma de seleção vemos, ainda no texto da autora supra citada ${ }^{69}$ que: "... o que se observou foi uma quantidade significativa de auxiliares de saúde contratados a partir das comunidades de base, inclusive com prática de liderança política dentro delas...". (Smeke, ${ }^{69}$ pág.: 190)

Após a seleção, os auxiliares passavam por um periodo de treinamento para o exercicio de suas funções. Cabe ressaltar que o processo nos CS da PUCCAMP foi bastante semelhante tendo em vista, principalmente, que a quase totalidade dos docentes do Departamento de Medicina Social e Preventiva possuía vínculo com a Secretaria da Saúde além de um compromisso com o ideário do projeto.

Como dissemos anteriormente, após o convênio AIS (Pró Assistência), a rede básica passou a incorporar mais recursos tecnológicos e, paralelamente, a rever modelos assistenciais o que se deu, tanto por meio de reciclagem das equipes dos serviços básicos, como por mudanças nas políticas de contratação e de capacitação de recursos humanos.

Paralelamente, na área da enfermagem, em 1986, é promulgada a Lei do exercicio Profissional que previa a extinção do grupo de atendentes de enfermagem, como categoria profissional, prevendo um prazo de dez anos para a extinção desses quadros. Como forma de promover o registro dos trabalhadores 
atendentes, prevendo sua posterior capacitação, o Conselho Regional de Enfermagem registrou todos os profissionais da área. $\mathrm{Na}$ ocasião, os antigos auxiliares de saúde receberam registro como atendentes de enfermagem.

Para capacitar esse grande contingente profissional, nacionalmente, foi criado o Projeto Larga Escala, iniciativa das próprias instituições de Saúde. Projeto este que, de acordo com Santos e Souza, ${ }^{65}$ nasce a partir da consideração do papel social de tais profissionais e de sua importância para a consolidação do SUS e da Reforma Sanitária. O Projeto responsabilizava-se pela componente profissionalizante do curso de auxiliar, devendo os alunos inscritos possuir certificado de primeiro grau, ou cursá-lo no ensino regular ou supletivo de forma concomitante ou mesmo posterior, ficando a entrega do certificado com o título auxiliar de enfermagem atrelada ao certificado do $1^{\circ} \mathrm{grau}$.

Guimarães, ${ }^{34}$ ao realizar uma retrospectiva sobre a preocupação estatal com a adequação da formação de profissionais às necessidades dos serviços, coloca que, a partir de 1963, o Ministério da Saúde e a Organização Pan-americana de Saúde (OPAS), juntamente com o UNICEF (Fundo das Nações Unidas para a Infância) iniciaram atividades de formação de pessoal de nível médio, havendo outras iniciativas posteriores. A experiência do Projeto Larga Escala, surgiu no início da década de 80 , sob coordenação da OPAS, envolvendo os Ministérios da Saúde, Educação, Ciência e Tecnologia e Previdência e Assistência Social.

De acordo com a autora:

"O objetivo principal do Projeto Larga Escala é a formação em Serviço (...). A inovação desta proposta é a aplicação prática de uma das teorias mais progressistas da área educacional - a pedagogia da Problematização- que utiliza como premissa básica a visão de que o conhecimento é construido e reconstruído pelos sujeitos do processo ensino- aprendizagem..." (Guimarães, ${ }^{34}$ pág.:1) 
A formação em Larga Escala, em Campinas, iniciou-se em dezembro de 1988 por iniciativa de um grupo de enfermeiros com atuação nas secretarias estadual e municipal de Saúde. Anteriormente houve um amplo movimento de capacitação de profissionais universitários da rede pública envolvendo também docentes e enfermeiros das escolas de terceiro grau e dos Hospitais Universitários e serviços da PUC e UNICAMP, denominado Capacitação Pedagógica. A experiência, para os profissionais da Secretaria, teve caráter multidisciplinar. A partir dessas capacitações e da sensibilização dos profissionais, teve início a construção da grade curricular do curso, a partir dos marcos pedagógicos já adotados. A formação foi organizada de forma modular, diversa da do ensino tradicional, fragmentado pelas amarras das matérias e disciplinas. Assim o currículo foi composto por cinco áreas (conjunto de conteúdos), com previsão de momentos que envolviam atividades de cunho teórico (concentração) e prático (dispersão), preferencialmente utilizando como campo, o local de trabalho do aluno. Para os enfermeiros, toda essa movimentação representou momento bastante particular. Cremos que, de grandes possibilidades de afirmação do papel do profissional, como educador. Também de legitimação em toda a rede, principalmente frente aos auxiliares. Há que se ressaltar o compromisso político com a reforma sanitária dos profissionais responsáveis pela concepção e deflagração do processo no município. Como exemplo, vemos em Guimarães ${ }_{1}^{34}$ ao comentar a experiência, que o currículo do curso foi construído por um grupo de enfermeiros "motivados e comprometidos tanto com a profissão como com a questão pedagógica”. A proposta continha mecanismos processuais de avaliação, por meio da atribuição de conceito (apto ou não), e momentos de recuperação paralelos ao curso. O Projeto funcionou, em 
Campinas, até 1996, com a formação de 304 auxiliares. Também, no período, o número de enfermeiros na rede alterou-se significativamente, dos 14 contabilizados em dezembro de 1988 aos 210 no final de 1996. Podemos, por meio da análise do número de alunos formados, verificar que, em termos numéricos, a proposta revela baixa capacidade de resolução, frente ao ensino formal, quando em menor prazo a capacidade de habilitar estudantes é bem maior.

Guimarães $^{34}$ coloca que, inicialmente, o projeto enfrentou resistência de alguns enfermeiros responsáveis pelas unidades de Saúde, visto o acúmulo de funções decorrentes da supervisão das atividades de campo, postura mudada no decorrer do processo. Por informações dos profissionais que iniciaram o curso, soubemos que houve, também, resistência por parte de um grupo significativo de auxiliares de saúde, diante das novas perspectivas de trabalho que lhes eram proporcionadas. Muitas dessas resistências tiveram origem na perda de autonomia e mudança de papel em virtude do modelo assistencial.

Cabe ressaltar que, nos concursos públicos posteriores a 1989, a rede promoveu a inscrição de auxiliares de enfermagem já qualificados.

Dentre as profissionais do estudo, dadas as condições da amostragem, nenhuma das contratadas pela PUCCAMP como auxiliar de saúde foi entrevistada. Mesmo assim, quatro delas, ou seja, uma das técnicas de enfermagem e três das auxiliares, ingressaram na Prefeiturá como aưuiliaras de saúde e são funcionárias da Secretaria de Saúde desde o início dos anos 80. Essas auxiliares iniciaram capacitação na área de enfermagem posteriormente ao ingresso que no caso de todas, se deu em função da: Oportunidade de Emprego, por essa razão as profissionais inscreveram-se no processo seletivo para a função dada a oportunidade. Enfatizam ainda em suas trajetórias o fato de, na ocasião, atuarem 
em trabalhos na comunidade, o que era uma espécie de pré-requisito para a aprovação dessas pessoas e, em suas falas, preservam bastante o aspecto que tem por base a importância social que elas atribuem a si mesmas e à participação comunitária:

"Eu, na época em que fui escolhida, a gente, nós éramos trinta, e foi feito assim, uma pessoa mais engajada na comunidade tal ... Foram convocadas cinco auxiliares, só. E dessas cinco, a maioria morava no bairro há bastante tempo, já conheciam o bairro, a comunidade, depois, eu acho que não foi assim em nivel de formação, por exemplo não, que eu já tinha formação na área da enfermagem...Eu já era atendente, de hospital... Eu trabalhava na Casa de Saúde" Para argumentar que, no caso da seleção, o que era avaliado não experiência ou prática em Saúde: “Porque outras pessoas que foram escolhidas não eram profissionais da área da Saúde" (Técnica 1)

Trazemos o seguinte relato sobre o processo seletivo:

"A gente passou por uma seleção... A prioridade era ter sido morador do bairro, e você freqüentar alguma atividade do bairro...Eu era da igreja, eu ainda sou da igreja católica, foi uma das escolhas... E depois teve umas provas e eu fui em frente... Foi onde entrei na área da Saúde...Na época que abriu a inscrição eu fui fazer a inscrição para minha filha, mas minha filha só tinha 17 anos...e precisava ser de major, dal a pessoa que estava fazendo a inscrição falou: - não dá. Por que você não faz para você?... E foi onde ... Mas eu nunca tinha pensado antes, e antes de tudo eu era costureira, uma profissão totalmente diferente de enfermagem" (Auxiliar 2).

Interessante observarmos nessa fala que hoje a profissional vê-se como da enfermagem, embora na ocasião do seu ingresso a profissão de auxiliar de saúde não fosse considerada como de enfermagem.

Outra das profissionais também comenta aspectos da seleção e ressalta seu trabalho na comunidade: 
“Foi uma seleção dentro do bairro, onde foram tirados 8 funcionários. Dentro desta seleção teve entrevista, teste, né? E então eu pertencia à Sociedade de Amigos do Bairro... do Jardim Garcia... Foi por acaso, foi minha cunhada que foi se inscrever, mas pela idade dela não podia, e eu fui junto e me inscrevi. Eu estava sem trabalhar nessa época... Eu sempre trabalhei com metalúrgica" (Auxiliar 4).

A terceira das auxiliares não comenta se tinha ou não, na ocasião do ingresso, vivência em trabalhos comunitários. De forma diferente das outras prendese à descrição do ingresso como decorrente da oportunidade de emprego e comenta sua experiência em trabalhos anteriores:

"Antes eu sempre trabalhei. Na fábrica de chapéus Vicente Cury uns quatro anos, fui babá de uns gringos né? Trabalhei em salão de manicura, e costurava um pouco assim... Eu nunca pensei que fosse trabalhar na área da

Saúde apesar que já fazem 16 anos, é um lugar que eu gosto" (Auxiliar 1)

A capacitação das Auxiliares de Saúde deu-se de forma mais lenta, por meio do Projeto de Formação em Larga Escala, a profissional aqui denominada técnica 1 , complementou sua formação cursando, no ensino formal, técnico de enfermagem.

As outras duas profissionais do grupo já ingressaram por ter formação média, uma delas, auxiliar, contratada para serviços temporários pela Secretaria de Saúde e a outra, técnica de enfermagem, contratada pela PUC. A primeira delas atribui sua opção por profissionalizar-se na área à: Afinidade pela área da enfermagem, esse interesse determinou que procurasse curso de atendente, de quatro meses, e ela o atribui tanto ao aconselhamento de uma enfermeira conhecida como ao fato de gostar da profissão:

"Ah, eu trabalhava em padaria, em confecção trabalhei... De repente, tem uma enfermeira que mora no apartamento, onde meu pai morava, no prédio, no condomínio, e foi isso, acho que conversando com ela também...

Diferente, né? E eu gostava, eu tive uma irmã que operou de apendicite e inflamou, então deu aquele mau cheiro e eu gostava de cuidar dela..." (Auxiliar 
Interessante perceber que a identificação com o trabalho na enfermagem deu-se a partir da percepção da sua própria capacidade de cuidar e de lidar com o mau cheiro e a dor. Se era possivel gostar dessas atividades, então, poderia tornarse profissional.

A técnica de enfermagem contratada pela PUCCAMP começou a trabalhar na área por: Acaso, como exemplo, trazemos sua fala:

\section{“ ...Eu não escolhi Enfermagem, ela me escolheu...” (Técnica 2)}

Relata que iniciou atividade profissional em um hospital como técnica em patologia e foi chamada a trabalhar com enfermagem por uma necessidade da instituição. Como as outras profissionais, capacitou-se após a inserção no Serviço de Saúde, cursando o auxiliar e depois o técnico, o que, em princípio, indica afinidade pelo exercício profissional e busca por maior qualificação.

\section{O ingresso no Centro de Saúde Integração}

Tanto a auxiliar 3 , como a técnica 2 ingressaram no CS dada a proximidade do Serviço de suas casas. A técnica, contratada pela PUC, soube da existência da vaga por morar próximo do Serviço e ter sido informada pelas pessoas conhecidas que ali trabalhavam.

Todas as outras profissionais atuam no CS por morarem nas áreas de abrangência dos CS da Vila Pe. Manoel da Nóbrega e do Jardim Garcia, cuja junção deu origem ao Serviço. Em suas falas comentam que a ida para o Integração deveu- 
se à união destes serviços, quando da construção do prédio onde está instalado o Integração:

\section{"Ah sim, tinha o Garcia e tinha outro Centro de Saúde que era o} Nóbrega, mas os dois eram pequenos, então o pessoal veio para cá. Ai foi implantado aqui na Vila Castelo Branco para não ficar assim, o Garcia vai pro Nóbrega e esse problema, então fez o terceiro e daí teve uma seleção do nome, e aí teve uma votação, porque nós queríamos o Garcia e outros queriam o Nóbrega, então um paciente, né, ele sugeriu: "Por que não chamam Integração, se é uma Integração dos dois bairros?" $E$ ai ficou Integração"(Auxiliar 4)

Das falas das auxiliares pudemos apreender que a junção dos dois serviços não foi um momento tranqüilo para as duas equipes, pois ambas acreditavam ter seu próprio modo de trabalhar. Os serviços de origem, dada a história da constituição dos CS em Campinas, funcionavam como extensão de suas casas. Também, em momento posterior, com a adesão da PUC ao Serviço, a equipe, principalmente a auxiliar, viveu novas situações de conflito. Na seqüência de nossa entrevista o coordenador administrativo, ao apontar as deficiências do CS, coloca que o conflito entre os auxiliares originários dos três serviços está superado, embora atualmente tenha sido substituido por conflito de outra natureza, entre os grupos de auxiliares que trabalham nos turnos diurno e noturno.

\section{Auxiliares de Consultório Dentário}

Vemos em Bittencourt ${ }^{04}$ que a atividade dos auxiliares em odontologia (atendente em consultório dentário e técnico em higiene dental), é reconhecida pelo Conselho Federal de Educação desde o ano de 1975, embora tenha sido aprovada pelo Conselho Federal de Odontologia apenas em 1984 (decisão 26/84), revista em 
1987. Até hoje o exercício deste profissional não é regulamentado em lei, por veto presidencial, apesar da aprovação pela Câmara dos Deputados em 1993. Portanto, esse exercício é fiscalizado pelo Conselho Federal de Odontologia (resolução 185/93). Em decorrência, a criação destes cargos por órgãos estatais pode dar-se, exclusivamente, por meio de regime estatutário.

Desde o início, esta atividade profissional foi concebida para ampliar a ação dos profissionais de odontologia (dentistas), por meio de atividades de promoção e prevenção em Saúde Bucal e mesmo aumentar a capacidade de atendimento individual dos dentistas (trabalho a quatro mãos). A regulamentação destas práticas não é aceita por muitos profissionais universitários da área, com exercício liberal, por espírito corporativista, o que certamente influenciou o veto presidencial já citado. De qualquer modo, o exercício profissional dos atendentes, na criação da categoria profissional era facultado pelos Conselhos Regionais, mediante um atestado de proficiência emitido por profissionais de nível superior. No município de Campinas não há cursos regulares de formação.

Face às dificuldades de formação destes profissionais, e mesmo diante do questionamento acerca da adequação do perfil do profissional já inserido na rede, a Secretaria Municipal de Saúde de Campinas, decidiu proporcionar a formação de todos os auxiliares e técnicos por meio do Projeto Larga Escala, iniciado em 1992, tal como o de auxiliar de enfermagem. O curso é modulado, com critérios de desenvolvimento também semelhantes.

A profissionalização das auxiliares por nós entrevistadas, da mesma forma que de muitas das auxiliares de saúde, deu-se após o ingresso na rede municipal. Os primeiros trabalhadores da área foram contratados pela rede de CS, como auxiliares de saúde no início da década de 80 . Anteriormente, havia alguns desses 
profissionais vinculados à Secretaria da Educação, atuando em creches e equipes móveis para atendimento a escolares.

Ao analisarmos as trajetórias das duas profissionais da área e os motivos para ingresso na profissão, identificamos as seguintes categorias: Acaso e Oportunidade de emprego. Como exemplo da primeira delas há a auxiliar que trabalhava numa creche municipal e estava afastada das atividades para as quais fora contratada, segundo ela, por apresentar problemas ao lidar com crianças. Por isso foi alocada para auxiliar o dentista, identificando-se mais com este trabalho. Esse recurso, de afastamento do profíssional, é utilizado pelo serviço público municipal e denominado "disfunção". Na ocasião do concurso para a função de $A C D$, foi considerada apta a exercê-la, sendo aprovada e iniciando suas atividades no Serviço em 1995. A sua formação pelo Projeto Larga Escala deu-se em periodo posterior ao da nossa entrevista. Já a técnica, que anteriormente trabalhava em escritório de despachante, e se inscreveu em concurso para a função de auxiliar de saúde, dada a oportunidade de trabalho, descreve o processo da seguinte forma:

"Porque foi assim, na época em que eu entrei na prefeitura, eu entrei porque eu precisava trabalhar, nunca tinha trabalhado com dentista. Eu trabalhava em um escritório de despachante... Não, na época não foi um concurso para auxiliar de dentista, foi para auxiliar de saúde. Eu fiz a prova dai, quando escolhi eles me falaram que era para trabalhar com dentista.

Trabalhei muitos anos em escolas da Prefeitura, com as equipes móveis, e daí eu fui tomando gosto pela coisa. Dai pedi transferência para o Centro de Saúde que é bem perto da minha casa e aí surgiu o curso técnico para fazer. Como eu já tinha muito, tenho dez anos de Prefeitura, então comecei a adorar odontologia e queria me expandir mais, dai desde 90 eu sou técnica, mas a Prefeitura não tinha esse cargo, e até hoje não tem...Teve o Curso de Larga Escala para Técnico... Foi um ano de curso para ser uma coisa mais técnica mesmo... porque ACD não mexe muito mais". (THD)

Posteriormente, diante das dúvidas da entrevistadora, esclareceu que, após ingresso na rede, em 1985, recebeu certificado para exercício da função de ACD e 
fez um curso técnico em São Paulo no ano de 1990. Em 1993, por determinação da Secretaria da Saúde, necessitou ingressar em curso de larga escala para auxiliares e, na seqüência, para técnicos.

Como forma de enfatizar sua afinidade pelo trabalho em odontologia, e mesmo um desejo de ascensão profissional, faz o seguinte relato:

"Então eu gosto, se eu pudesse e tivesse tempo, assim, eu faria odontologia, porque eu entrei assim não sabendo nada, mas com o passar do tempo, assim a gente vai tomando gosto pela profissão... eu gosto bastante".

O ingresso no Centro de Saúde Integração

Ambas optaram pelo CS dada sua proximidade de suas casas 


\section{Comentários relativos às trajetórias dos}

\section{Profissionais}

Ao analisarmos os motivos de escolha da profissão de todos os segmentos profissionais, observamos dois movimentos distintos, o dos antigos auxiliares, atraídos pela oportunidade de emprego e o dos profissionais de nivel superior e mesmo da equipe de enfermagem de nivel médio, que já ingressaram como tal, e procuraram capacitar-se para o exercício profissional, baseados em uma suposta aptidão (vocação). Também é importante ressaltarmos que essa vocação, ou, pelo menos, o ajuste às atribuições profissionais, manifestou-se nas auxiliares, após a seleção, pois concretamente, todas as entrevistadas atuavam no Serviço há aproximadamente vinte anos.

As formas de ingresso no CS aqui relatadas são exemplares das distintas políticas para recrutamento e seleção de recursos humanos adotadas pela Secretaria de Saúde, tanto para os médicos, indicados por seus pares no inicio dos $\mathrm{CS}^{69}$ pela suposta afinidade com os princípios políticos do projeto, a maior parte deles generalistas, como para os atuais profissionais, aprovados em concurso e portadores de título de especialista (ginecologistas, pediatras e psiquiatras, e mesmo com residência em clínica médica). Um primeiro pensamento que nos ocorre é que as motivações dos primeiros médicos inseridos na rede eram diversas, ou que, eles se identificavam com a proposta filosófica e política contida no ideário da 
prática dos serviços. Atualmente, a busca se dá como decorrência da oportunidade de trabalho assalariado, o que também ocorre com os dentistas.

Podemos ainda identificar em todo grupo, resquicios do que chamaremos vínculo, presumivelmente, de maior afinidade politico filosófica com o projeto da reforma sanitária e da Saúde Pública, constituído pelos professores e coordenadores que fizeram opção por trabalhar na área da Saúde Pública, e dedicaram a ela seus esforços de capacitação profissional e mesmo de reflexão. Também é de se supor que os antigos auxiliares de saúde, dadas as características de sua inserção nos serviços, além da própria formação em larga escala, possuam esse mesmo vinculo.

Com relação aos enfermeiros, a expansão do quadro de profissionais da área na rede data do início da década de 90 . Quando da criação dos CS municipais havia muito poucos profissionais contratados pela rede municipal e estes não tinham atuação direta nos CS. Atuavam por meio de supervisão de procedimentos da área da enfermagem. Já nos serviços estaduais sempre houve participação do enfermeiro. Como já relatado nos quatro CS da PUCCAMP ocorria a atuação dos docentes do Departamento de Enfermagem de Saúde Pública e Mental, embora essa participação não fosse bem aceita pelos profissionais médicos (docentes) sob - argumento de que a atuação de enfermeiros não era necessária neste. Posteriormente, o argumento utilizado era que os enfermeiros não tinham um projeto profissional para a prática nos serviços, o que, em uma análise mais isenta, feita a quase vinte anos depois, por essa autora, talvez fosse verdade, a nosso ver justificada pela formação escolar dos enfermeiros de então, voltada mais às ações de educação, prevenção e de supervisão de equipe auxiliar. Ocorre que, nos antigos CS, os auxiliares tinham papel destacado na realização de consultas e 
atendimentos a pessoas e grupos populacionais identificados como de baixo risco, embora também se responsabilizassem por alguns procedimentos de diagnóstico e prescrição padronizados sob supervisão médica.

Kirshbaum $^{36}$, ao estudar a prática das auxiliares, coloca tais características da divisão de trabalho entre, predominantemente, médicos e auxiliares, enfatizando que a supervisão da atividade das auxiliares ficava a encargo dos médicos e enfermeiros. Dado o pequeno número de enfermeiros na rede, no período em questão, podemos supor que as atividades cotididianas das auxiliares eram de responsabilidade direta dos médicos.

Observamos, também, não haver, por parte dos que concebiam o trabalho da rede de serviços, a proposta de atuação em equipe multidisciplinar dada a ideologia vigente, e a simplificação proposta pelo modelo de assistência e, no caso dos enfermeiros, uma visão, distorcida, de que a eles coubesse, nesse nivel da atenção, apenas administração (de quê?) e supervisão (como?). Parece também, que não havia confiança no compromisso político dos outros profissionais, fato confirmado por meio da leitura do estudo realizado por $\mathrm{Garcia}^{28}$ ao comentar o início do processo de constituição dos CS da PUC, assim:

"Entretanto, em relação ao trabalho multiprofissional, a proposta se limitava ao auxiliar e ao médico generalista, pois entendia-se que esses seriam "os únicos" a possuir "a generalidade do conhecimento necessária á compreensão do processo saúde doença". Esta visão limitada da interdisciplinaridade, era explicitada pela opção do próprio 'grupo' pela medicina generalista, e por considerar que os demais profissionais de saúde não posuiam "um projeto específico em atenção primária", o que exigiria a redefinição de papéis através da aquisição de "uma visão global do processo saúde doença"

(Garcia, ${ }^{28}$ pág. 102, trecho entre aspas citando DMSP, 1982) 
Cabe ressaltar que a houve, por parte dos outros profissionais, um movimento de reação, embora, discutir presença e espaço com quem tinha tanta certeza de propósitos não fosse situação fácil e, nem sempre agradável.

Martins, ${ }^{43}$ também se refere a essas dificuldades iniciais de integração entre os profissionais, ocorridas por ocasião da passagem do antigo ambulatório para o CS Castelo Branco da PUCCAMP e da criação dos outros serviços da Universidade. No ambulatório trabalhavam, além de docentes médicos de vários departamentos do curso de medicina, enfermeiros (docentes), assistente social e psicóloga (assistenciais), o que, em principio, implicava a adoção de modelo multiprofissional, extremamente discutido por todos. Em síntese, na interpretação da autora: ${ }^{43}$

"Não há dúvida de que esse processo trouxe à tona conflitos de ordens diversas derivados do corporativismo e do próprio modelo assistencial simplificado que incorporava na equipe o profissional médico e o auxiliar de saúde ou da necessidade de definir o papel de cada profissional no serviço de atenção primária ou, ainda, da necessidade de estabelecer os limites da atuação dos diversos profissionais neste trabalho." (Martins ${ }^{42}$, pág. :4)

Ao retomarmos as trajetórias das enfermeiras e de duas das profissionais de nível médio (auxiliar 1 e técnica 2), por nós entrevistadas, vemos que, enquanto para os médicos e dentistas o ingresso no CS deu-se pela oportunidade de trabalho assalariado, para estas profissionais, atuar no CS significou a oportunidade de saida do hospital. Movimento semelhante foi observado por Gonçalves, ${ }^{32}$ em cujas entrevistas os enfermeiros manifestaram o sentimento ambíguo de simpatia pela Saúde Pública e antipatia pelo hospital. Cabe ressaltarmos que as enfermeiras por nós entrevistadas, não manifestaram desgostar da atividade hospitalar e sim a necessidade pessoal de outra modalidade de emprego, ou a própria simpatia pela 
Saúde Pública. Já a auxiliar e a técnica, falam do cansaço decorrente do trabalho em hospital.

Ficou-nos ainda evidente que as antigas auxiliares de saúde, ao relatarem sua trajetória, de forma recorrente, prendem-se mais ao momento do ingresso. Durante a entrevista falaram sobre sua capacitação posterior, ao serem indagadas. Parece-nos exemplar que, uma das auxiliares ao comentar seu ingresso no Projeto Larga Escala, relata que o fez obrigada, isto é, por exigência da instituição. Acreditamos que isso possa ser explicado pela antiga inserção social dos auxiliares de saúde, membros destacados de suas comunidades e extremamente valorizados pela Secretaria de Saúde que, apesar de agora mais qualificados, perderam seu papel de elo, e ganharam subordinação ao enfermeiro. 


\section{VI-1:O Centro de Saúde e o SUS - Segundo Eixo}

\section{A Finalidade do Serviço}

Pensar finalidades do Serviço, considerando sua inserção em um conjunto de unidades de prestação de assistência à Saúde, por sua vez inseridas em dadas sociedades, nos remete a aspectos teóricos relativos à configuração dos modos de trabalhar, denominados "modelos assistenciais", conceito trazido por nós anteriormente a partir do trabalho de Paim ${ }^{57}$ e também discutido por Campos, ${ }^{12}$ para quem:

"Modelo assistencial deveria ser conceituado como o modo como são produzidas ações de saúde e a maneira como os senviços de saúde e o Estado se organizam para produzi-las e distribuí-las.

Esse novo conceito tem duas utilidades imediatas: uma analítica, na medida em que permite identificar um determinado modo de produção existente; e outra operacional, que possibilita a construção de novas politicas para além da anunciação de diretrizes gerais, ou seja, permite pensar modelos assistenciais novos, imaginados enquanto objetivos estratégicos a serem atingidos". (Campos, ${ }^{12}$ pág.: 53)

Diversos pesquisadores da Saúde Pública, no Brasil, têm-se dedicado a compreender modelos adotados nas diversas circunstâncias históricas e sociais, estabelecendo para eles denominações a partir de padrões gerais de funcionamento e de origens teórico-conceituais. Ocorre, na implementação do SUS, a nosso ver, um movimento inverso, à medida que, modelarmente, a partir das diretrizes da VIII Conferência Nacional de Saúde, ${ }^{14}$ de forma mais enfática, e das 
movimentações posteriores, surge uma concepção de modelo, ainda não implementado, e, como dissemos anteriormente, contra-hegemônico no projeto de caráter neoliberal adotado pelo Estado brasileiro.

Assim, se de forma real, convivem inúmeros modelos, visto não haver um corte de passagem de um para outro, é de se esperar que nas mentes se reproduza esta situação, de tal forma que as representações sejam reflexo (e reflitam) as transições e os conflitos entre as inúmeras formas de ver e representar as finalidades do CS.

Em nosso caso, e em conseqüência das considerações expostas anteriormente, de forma diversa ao que ocorreu quando da descrição das trajetórias nas quais observamos nitida distinção entre os que tinham formação universitária e os profissionais de nível médio, vemos que, ao manifestarem suas opiniões (representações) sobre as finalidades do Serviço, os profissionais, de forma não diretamente relacionável à escolaridade, o fazem em atendimento às próprias visões de mundo. Veiculam modos de pensar presentes na sociedade, com posições advindas do senso comum, caso de três das auxiliares (uma de enfermagem e as outras duas de consultório dentário) para quem o Serviço prestase a atender às pessoas sem convênio. Outra leitura semelhante, característica da concepção neoliberal do Estado que, segundo Sader \& Gentili, ${ }^{64}$ se responsabiliza pouco pela execução das políticas sociais e, ao fazê-lo atende apenas aos completamente destituídos de recursos. Dentre a gama de posições, a maior parte dos profissionais colocou as finalidades com base no desenvolvimento da Saúde Pública no pais e nos modelos assistenciais vigentes.

Cada uma destas representações tem o espaço de ancoragem nos diversos paradigmas que norteiam a própria Saúde Pública. Assim, para os profissionais com 
formação nesta área e domínio dos conceitos referentes às Políticas de Saúde e aos pressupostos do SUS, prevaleceu a questão Porta de entrada. Para os que têm experiência no Serviço, embora sem formação em Saúde Pública, prevalece Atenção Primária à Saúde, referindo-se às concepções de Alma-Ata, ou colocando ênfase no papel educativo-preventivo do Serviço e nas necessidades do CS de normatizar a demanda e, quiçá, a vida, como veremos na seqüência desse estudo.

\section{Profissionais de Nível Superior}

\section{Docentes}

Uma das categorias empíricas identificadas nos discursos dos docentes é a consideração de que o CS tem por finalidade funcionar como:

\section{Porta de Entrada do Sistema.}

Os docentes de enfermagem, farmácia, nutrição, medicina e terapia ocupacional, em suas falas comentam as diretrizes da VIII Conferência Nacional de Saúde e do SUS, que têm caráter mais normativo. Além disso fazem uma reflexão acerca do modelo assistencial que prevê a Atenção Integral à Saúde das pessoas, e ações de vigilância à saúde. Suas representaçōes, em primeira instância, tomam por base o conhecimento formal do campo da Saúde Pública, onde encontramos os 
principios de hierarquização do Sistema e a finalidade precipua da prestação de assistência à saúde individual e coletiva.

De forma complementar, um dos docentes de medicina (2) enfatiza o caráter de formaçāo no Serviço, considerando assim que o CS tem dupla finalidade:

\section{"O Integração. Ah eu acho que o Integração tem, cumpre uma dupla finalidade, né? Ele tem a questão Assistencial em que está inserido pra dar respostas a demanda daquela população, e ao mesmo tempo tem uma finalidade de ensino. Acaba sendo um centro de estágio de várias disciplinas...". (Docente de medicina 2)}

De todo o grupo de professores, é o único que destaca a caracteristica de formação no Serviço, ou sua dupla finalidade. Posteriormente veremos que a coordenadora acadêmica manifesta-se de forma semelhante. Os outros relacionam o CS à população e ao Sistema de Saúde, ou seja, não o têm representado como órgão de formação, como se essa finalidade fosse inerente a ele ou a qualquer campo de estágio.

Outra categoria obtida nas falas desse grupo de profissionais foi: O Centro de Saúde deve realizar ações de prevenção e educação.

Como forma de respaldar a afirmação, os docentes de psicologia, fisioterapia e fonoaudiologia fazem referência à atenção primária à saúde, compreendendo o conceito de duas diferentes maneiras, a primeira referindo-se ao modelo assistencial, simplificado, segundo o qual, com recursos mínimos haveria prestação de assistência; a segunda, à hierarquização do Sistema, ocasião em que o uso do conceito é feito como forma de definir o primeiro nivel de atendimento. Este envolve ações mais simplificadas e, principalmente, as de promoção da Saúde, ressaltando a educação e a prevenção primária. Assim, prevenção da doença é a finalidade maior. Cabe ressaltarmos, a presença, nestas falas, da dicotomização prevenção - 
cura. Assim, no CS que funciona bem as ações de prevenção devem ter maior ênfase que as destinadas à reparação (cura, reabilitação). Também não fica claro, a partir das suas falas, quais seriam as competências dos outros níveis de atenção, talvez porque se baseiem nas ações desenvolvidas pelos profissionais de sua área específica. Como exemplo vemos que, diante da própria representação das finalidades do Serviço, os professores de psicologia e fisioterapia estabelecem críticas às suas práticas:

"E nós da psicologia, acabamos dando um pouco de Atenção Secundária, quando a gente acaba fazendo o atendimento por um tempo determinado, né?...E tem mais um objetivo de intervenção na própria doença... Não diria curativo (riso)... Tem sido dificil a gente fazer trabalho preventivo porque a gente não dá conta, o que chega é, tá tão estropiado que como é que você vai (riso) fazer prevenção onde... as coisas estão muito instaladas". ( Docente de psicologia).

De fato, ao analisarmos o modelo assistencial do CS, vemos que o trabalho de psicologia, no mais das vezes apresenta cunho individual e ocorre mediante encaminhamento de outros profissionais, ao se defrontarem com as necessidades. Ocorre ainda uma procura espontânea por parte da população, em ambos os casos, e encaminhamento pelas escolas da área, por exemplo. Também avaliamos que a clientela, muitas vezes, necessita de acompanhamento psicoterapêutico, ou reabilitador, caso da fisioterapia. Por outro lado, os profissionais da área podem estar reproduzindo uma prática da clínica no CS, o que prejudica o Serviço e, a nosso ver, a qualidade pedagógica dos estágios de alunos, privados do contado com as atividades dos grupos de gestantes, mulheres e hipertensos, por exemplo, e aquelas de vigilância à saúde. Esse contato poderia oferecer oportunidade de se trabalhar outras visões da saúde mental, do próprio Serviço, além de uma vivência multidiscipinar. 
Já o docente de fisioterapia destaca uma mudança de enfoque em seu trabalho e no modelo assistencial do CS em si:

"Inicialmente, até como programa para a fisioterapia desenvolver aqui, era justamente pra gente não ter, recursos minimos, ou nem recursos... Era para trabalhar mais na área da Atenção Primária, ou seja, com hipertensos, diabéticos, orientação com gestantes... Então, por uma demanda da comunidade, a gente tem alguns recursos que podem dar algum suporte ao atendimento... O que não era inicialmente o projeto do curso". (Docente de fisioterapia)

Esse professor faz referência ao caráter de reabilitação de suas atividades, e à compra de alguma aparelhagem necessária, dadas as demandas da população usuária do Serviço, onde há muitos idosos e outros tipos de clientes com seqüela. Dá prioridade a esse tipo de ação, não participando de outras atividades do Serviço, tais como as educativas (nos grupos) ou as de vigilância à saúde. Neste caso, cabe ressaltar que o curso de fisioterapia mantém ambulatório para atendimento em anexo ao Hospital Universitário, e que o estágio no CS poderia privilegiar outras experiências de atuação, que, como em psicologia, seriam oportunidades de interação com outros alunos e profissionais. Martins ${ }^{36}$, em seu estudo sobre interdisciplinaridade no CS, observou que os alunos de fisioterapia não puderam vivenciar experiências interdisciplinares. O curso de psicologia, embora centre o trabalho no atendimento individual, atua em grupos de forma extra-mural, em instituições da comunidade. 


\section{Médicos}

Uma das categorias obtidas a partir do discurso de um dos profissionais da área sobre a finalidade do Serviço foi Consultar as pessoas mais carentes.

Ao mencionar o termo "consultar", a nosso ver o profissional não considerou todo um conjunto de ações realizadas pelo CS, fora das consultas médicāás individuais. Assim, enfoca essa ação, como se o Serviço realizasse apenas consultas (como num grande consultório médico).

Por outro lado, dado o acesso do profissional a um determinado conhecimento, sua representação é calcada na cultura do neoliberalismo, e na consideração de que, pessoas não carentes devam ter convênio médico.

Justifica sua opinião na alta demanda de pacientes, e no fato de haver, segundo ele, pessoas com convênio que procuram pelo Serviço. Assim:

"A finalidade é (pausa) consultar as pessoas mais carentes. Aí já existe uma dúvida muito grande... Quais dos pacientes nós deveriamos atender?... Existe uma sobrecarga no Serviço, se você amplia o Serviço provavelmente a demanda aumentaria também, isso é lógico". (Clínico)

O raciocínio é elaborado sem considerar se as necessidades de saúde da população, que geram uma certa demanda ao Serviço, ocorrem de fato, ou se há outra determinação, como seno caso do mercado, que aumentando a oferta, ou melhorando o produto, faz crescer a procura. Discute também o uso do CS pelas pessoas que têm convênio: 
"... Até que ponto vai se bloquear a entrada, o atendimento do paciente que tem convênio médico. Às vezes isso acontece... O paciente tem convênio, mas prefere usar o Serviço ... Então, essa é aquela grande discussão...". (Clinico)

Prossegue comentando que, apesar dos convênios, alguns procuram o Serviço por causa dos medicamentos ou exames laboratoriais, o que a seu ver suscitaria outras discussões. Ressalta as dificuldades causadas ao Serviço por pessoas que consultam em outros locais e o procuram por causa do fornecimento de medicamentos e também pelos exames laboratoriais. Coloca a discussão da finalidade do Serviço, em função da alta demanda de clientes em sua área e da própria sobrecarga:

"Então, realmente, qual é o limite? Isso que eu sempre coloco para o $R$.(coordenador): Que um dos desgastes do clinico é manter uma porta de entrar...Qual é o limite?... Chega paciente mal, você tem que atender. Se chega outro acidente de trabalho, tem que atender. Então que limite a gente tem?... Essa é uma parte desgastante para o clínico. Até que ponto você fala, 'bom chegou o meu limite'...Você tem um determinado número de consultas e de repente chega outro paciente...uma urgência. Claro que vai atender. Mas e o outro que pode esperar? É difícil delimitar isso por normas, tem que ser assim , como também é difícil quando se procura padronizar em termos gerais de atendimento médico. Atendimento médico deve durar quanto tempo?...". (Clínico)

O profissional prossegue respondendo à questão por ele mesmo formulada, ocasião em que se faz uma crítica a padrões e normas estabelecidas para a produção e produtividade médicas:

"Depende. Uma consulta simples pode ter um tempo curto. Uma consulta mais complicada, atendimento maior... Qual o tipo de atendimento que você procura dar pro cliente? Então se usa a média, né? Em média... se calculou 15 minutos, pra um pode ser pouco, pra outro pode ser muito." (Clínico) 
Cabe lembrarmos que as agendas do CS são abertas com o número máximo de doze consultas por turno, tempo médio de vinte minutos.

Essa representação das finalidades do Serviço, em nosso ponto de vista, está vinculada, única e exclusivamente ao fazer cotidiano, decorrência do modelo assistencial, numa área em que a demanda é maior (clínica). O médico se vê comprometido a atender quem chega, sentindo-se sobrecarregado, e enquanto trabalhador critica a sobrecarga e a imposição de limites a ele e aos usuários. Como forma de racionalizar o trabalho propõe o atendimento aos mais carentes. Apesar das intenções para que melhore o Serviço, com os desprovidos de recursos tendo acesso (ao médico), não faz referências ao contingente de pessoas adultas residentes na área à já observada, insuficiência no número de clínicos face às necessidades de Saúde da população.

Enquanto categoria teórica, a eqüidade foi também discutida na fala do profissional, isto é, ele ignora esse princípio, bem como a prestação da assistência integral à Saúde

Os outros profissionais discutem a finalidade do serviço, também a partir do seu fazer e de uma leitura do Sistema de Saúde hierarquizado. Em decorrência o CS tem como finalidade realizar: Açōes preventivas - Ações programadas.

Essa maneira de ver origina-se da vivência, não apresentando, portanto, vinculos maiores com diretrizes teóricas ou pressupostos conceituais. Parece-nos também significativo que nas falas de dois dos médicos (clínico e psiquiatra) a figura do coordenador (administrativo), seja apresentada tanto como meio de discussão das políticas e do modo de trabalhar, como a de impositor de limites Deste modo, a psiquiatra, após colocar que a finalidade do Serviço é relizar trabalho preventivo (atendimento primário), fala do coordenador de um modo hostil: 
"A Finalidade geral? É uma boa pergunta porque acho que você tem que perguntar para o coordenador (ri), porque acho que nem ele vai poder te dizer (ri)". (Psiquiatra)

Queixa-se do descaso do coordenador (administrativo) para com a equipe de saúde mental, em várias circunstâncias de nossa conversa. Um dos motivos é a falta de espaço para o atendimento: "A minha sala foi uma conquista de briga pessoal com ele..."

Assim, o coordenador figura para eles ou como o único responsável pelo modelo, ou como o interlocutor para discussão das políticas assistenciais. Se não há espaço, também a culpa é dele.

A pediatra também aponta para os princípios da hierarquização do sistema e começa a discutir finalidade pela "não finalidade":

"Eu acho que, em primeiro lugar, ele não tem a finalidade de atendimento de urgência. Somente se vier uma pessoa com uma urgência você vai fazer o primeiro atendimento, mas não deveria ser o lugar, a principio, para trazer essas pessoas." (Pediatra)

A partir dessa fala, podemos observar que caberia à população compreender e triar o Serviço a utilizar, de acordo com o grau de emergência do caso. Prossegue centrando-se nos princípios da hierarquização:

"E é um lugar, como a própria definição fala, Unidade Básica de Saúde, né? De atendimento primário. É o local onde se deve ter, principalmente, a prevenção das doenças, e da saúde, né? Prevenção e manutenção da saúde... Um local de orientação e programa de puericultura, de orientação de higiene, de orientação de alimentação, etc. E do próprio desenvolvimento e crescimento da criança, com consultas mais marcadas do que consultas, ah?

De encaixe, como nós falamos as ocasionais, né? E principalmente um trabalho de prevenção, o qual a gente não consegue fazer... de modo menos 


\section{individualizado e mais global. Não consegue fazer um trabalho de orientação} mais higiênica, programa de prevenção de verminose..." (Pediatra)

Outra proposta que fica clara nas é a relativa à regulação da demanda (e das necessidades da populaçāo/sociedade). A profissional, em sua fala, baseia-se no conceito da Puericultura, já abordado por Boltanski ${ }^{05}$, enquanto prática de educação e de adequação das pessoas, por isso mais um mecanismo de regulação.

Também o ginecologista coloca as funções de triagem do Serviço, embora ressalte que o CS deva ser resolutivo, no que é o seu papel: vacinação, coleta de citologia oncótica, pré-natal com exames de rotina e "pelo menos" um ultra-som por gestante (relata as dificuldades para conseguir o exame). Sua fala centra-se nos conceitos de hierarquização e de eficácia do Serviço, considerando que muitos CS encaminham sem necessidade, o que observa durante o atendimento no hospital.

De acordo com o tipo de inserção do profissional nas diversas áreas e de sua visão no trabalho com adultos, mulheres, crianças e saúde mental, varia a opinião sobre a finalidade do Serviço. A estrutura verticalizada estará aqui presente? Parece que nas representações dos médicos, ao analisarem o Serviço, sim. Deste modo a condução e mesmo a visão do conjunto do CS cabem, exclusivamente, ao coordenador, dado que os profissionais dão primazia quando discutem a finalidade do CS, a suas áreas de atendimento, e às consultas. Em algumas situações figuram a "vacinação", por exemplo. Assim, analisando os discursos dos médicos, podemos compreender que a representação das finalidades do CS é conformada a partir do cotidiano vivenciado, implicando falta de visão global.

As representações são então calcadas pelas visões de mundo, aliadas ao cotidiano. Deste modo, o clínico, passa a revelar uma posição neoliberal, ou seja o 
Serviço (estatal) tem por finalidade consultar as pessoas mais carentes. Já que a demanda é tão grande (e o número de clínicos insuficiente para as necessidades da população adulta), e não há condições de atender a todos, pelo menos os que não têm outra alternativa deveriam merecer maior atenção.

Os três médicos que enfatizam a prevenção colocam o Serviço como inserido em um sistema de hierarquia rígida, onde o CS é o primeiro nível. Assim, na Saúde Mental, precisa ser constituido um trabalho "a nivel de comunidade", não para atender o Doente Mental, exclusivamente. Em pediatria, o Serviço deve prestar-se ao acompanhamento das crianças e trabalho preventivo, que não é possivel ser feito dada a alta procura de consultas, e a pouca regulação da demanda. 0 ginecologista enfatiza o papel de referência do CS para os outros da rede e o funcionamento dela.

\section{Dentistas}

Dos comentários das profissionais acerca das finalidades do Serviço obtivemos as seguintes categorias empíricas: O Centro de Saúde deve realizar o primeiro atendimento às pessoas(dentista 1) e, tem a finalidade de prevenir doenças e promover a Saúde (dentista 2).

A dentista 1, comenta a hierarquização do sistema, deixando aparente a menor complexidade do Serviço e, de certo modo, o coloca como primeiro nivel em uma rede de serviços de diferentes complexidades. 
"Eu acho que, ele é função de base para a população. Antes de procurar um hospital, procurar um serviço mais especifico, né, pra Saúde, ele tem que agir em primeiro lugar, atender primeiro, né, e, se for - caso de coisas especificas dali direcionar pros hospitais, pros outros locais, eu acho". (Dentista 1)

A fala da outra profissional (dentista 2) contém forte conteúdo humanístico. Observamos ainda que, partindo de raciocínio baseado numa perspectiva ideal, segundo a qual, um dia as pessoas serão mais saudáveis, dicotomiza a prevenção e a cura:

"Olha seria proporcionar a Saúde. Então eu vejo assim (pausa) é

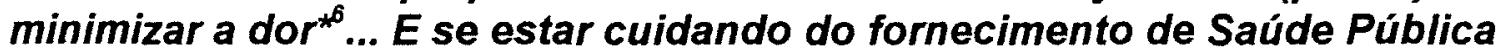
mesmo... Os médicos, os dentistas o pessoal de enfermagem. Então eu vejo como doação de Saúde. Acho que a gente trabalha pouco com a parte de prevenção da Saúde, ainda é muito curativa ... A gente... ainda vamos caminhar para ter um trabalho mais concentrado na prevenção...nos órgãos públicos, mas deveria ser...muitas vezes não é assim a nível satisfatório, vamos dizer assim ...é estancar.... Os problemas vão surgindo ... a gente não lida muito com o aspecto de Saúde, como um todo realmente...Eu acho que o CS seria aquele em que não houvesse doença... Seria para mim onde houvesse prevenção de doença, mas, no momento, no estágio em que a gente está é o mais curativo, menos preventivo, com algumas decisóes importantes, principalmente, na área de odontologia, de inversão da Atenção à Saúde...de estar centralizando a atenção odontológica em faixas etárias específicas e que vai proporcionar um adulto já com saúde bucal". (Dentista1)

Nesse discurso, apesar das boas intenções ficarem muito evidentes, não sentimos preocupação com o acesso à restauração e preservação dos dentes dos que não puderam (ou souberam) fazê-lo, por falta de educação em saúde e também de acesso ao trabalho do profissional dentista, o que acontece tanto em nossa cidade, como no país. Sabemos ainda que a Secretaria de Saúde, talvez com a intenção de fazer o possível, diante da falta de recursos para o real atendimento à demanda, opta por essa estratégia, distinta do modelo de Atenção Integral à Saúde.

As falas dessa profissional continham muitos "nés" seguidos de interrogação, buscando interagir com a entrevistadora. Foram aqui suprimidos como forma de dar major fluência ao seu discurso. 
Também podemos observar que os serviços de saúde, mesmo que excelentes, têm um papel bastante pontual na prevenção da doença social, principalmente quando decorrente da miséria.

Torna-se importante destacarmos que as duas profissionais, em suas falas, tenham compreendido e expressado sua opinião sobre a finalidade do Serviço a partir do todo, o que não ocorreu com o grupo de médicos.

Em termos gerais, podemos observar que o conteúdo dos discursos das duas dentistas contém características bem diferenciadas no que se refere à visão de mundo. A dentista 1, com um posicionamento mais formal, e a dentista 2 , que faz questão de comentar que sente o trabalho no Serviço como oportunidade de conviver com outros profissionais, menciona a riqueza das trocas e da interação. Esse posicionamento pessoal permitiu que ela se mostrasse muito interativa e espontânea durante nossa entrevista, o que nos faz refletir sobre a complexidade dos seres humanos, o que transcende à formação profissional e tantos outros aspectos, a nosso ver bastante ligados à personalidade de cada um.

\section{Enfermeiras}

A categoria obtida a partir das falas das duas profissionais acerca da finalidade do Serviço é que: O CS deve realizar prevenção.

Uma delas (enfermeira 1), enfatizou o papel do diagnóstico da situação de Saúde da população, como meio de execução de práticas preventivas adequadas. A 
outra profissional, embora ressalte que uma das finalidades seja prestar atendimento (consulta?), coloca a prevenção como finalidade maior. Além disso, reporta-se à busca da população, nem sempre necessária, por atendimento médico:

"Acho que ele tem uma finalidade de atendimento, mas eu acho que seria mais uma prevenção. Eu acho, na minha opinião, que as pessoas vêm aqui, não porque estão doentes, mas porque querem uma orientação, para conversar... Acho que criam o hábito, né, é fácil, toda hora que eu vou lá tem o médico, eu converso e vou embora, sabe que está aqui, na porta de casa... e tem grupos com outras maneiras de abordar, eles vêem". (Enfermeira 2)

Em sua fala também podemos notar a preocupação com a regulação da demanda ao Serviço, a mesma verificada no discurso de uma das médicas, ou mesmo com o fato da própria clientela saber que existem outras formas de abordagem. Poderia ainda ver a questão sob o (bom) aspecto do vínculo clientemédico- Serviço, observando que as pessoas podem necessitar de espaço para conversar, muitas vezes não mensurável pela análise objetiva de sinais e sintomas.

Ao considerarmos a repressão da demanda que ocorre no Serviço, por falta de médicos, principalmente para a população adulta, e o parâmetro de concentração de consultas que, para 1996, foi de 3,2 (consultas/cliente), o que não é indicador de excesso, notamos a fragilidade do argumento. Além disso, há no Serviço um grande número de usuários adultos e idosos, com quadros de hipertensão e diabetes e necessidades reais de assistência. 


\section{Coordenadores}

Os dois coordenadores, da mesma forma que um grupo de docentes ancoram suas representações relativas à finalidade do Serviço nos pressupostos do SUS e, mesmo que de forma diversa, se expressam partindo de uma visão de conjunto, colocam a questão da finalidade em uma perspectiva global.

Assim, da fala da coordenadora acadêmica apreendemos a seguinte categoria: O Centro de Saúde tem dupla finalidade: prestar assistência à Saúde da população e funcionar como um Centro Formador de Recursos Humanos.

De maneira semelhante ao grupo de docentes com formação em Saúde Pública, traz o conceito de porta de entrada e de atenção integral e ressalta a finalidade de ensino, colocada por um deles, exclusivamente. Comenta ainda que o Serviço não pode ser caracterizado como escola, mas que caminha nessa direção

De uma maneira bastante ampla e desprendida das formas mais tradicionais de abordagem, a categoria empirica obtida da fala do coordenador administrativo é: A finalidade do CS é diminuir o sofrimento. Após fazer essa afirmação dirigiu uma pergunta à entrevistadora: "E consegue?".

Depois da assertiva inicial e da pergunta não respondida, comenta o fato de o Serviço ser uma das formas de implementação de uma série de políticas sociais e sua parte num conjunto que envolve outros segmentos executores dessas políticas:

"O Centro de Saúde é parte de um todo... Só a Saúde não dá conta, todas as áreas são próximas: é Saúde, Educação, Promoção Social, Obras. Eu acho que todas as áreas deveriam trabalhar juntas.... Então, Obras faz uma avaliação da nossa, deste espaço, que é muito... por exemplo, porque a gente está mandando gente embora, então a gente precisa conseguir um espaço 
adequado para fazer as discussões, grupos educativos e tal. Eu acho um assunto muito sério...."(Coordenador administrativo)

Em sua fala o profissional passa das questões da organização bastante amplas do Sistema, de forma bastante orgânica, sem referir-se às diretrizes do SUS e da Reforma Sanitária, como muitos dos docentes, embora respaldado nesses princípios, para a vivência cotidiana do modelo assistencial. Em sua fala repleta de questões não respondidas pela entrevistadora, e talvez utilizadas como figura de linguagem pergunta a título de exemplo se, para a execução de um projeto na área da saúde bucal, realizado pelo CS em uma escola, houver necessidade de comprar escovas de dentes, quem pagaria por elas? A Saúde ou a Educação?

A questão é colocada como forma de demonstrar que a máquina pública fragmenta as ações, criando empecilhos para uma melhor organização do Sistema, de modo a articular as políticas sociais a cargo do município. 


\section{Profissionais de Nível Médio}

\section{Auxiliares de Enfermagem}

Uma das categorias obtidas acerca das finalidades do Serviço foi: Atender as pessoas e resolver os casos. A auxiliar 3, recém contratada, emite essa opinião considerando a hierarquização do Sistema e ressaltando que 0 atendimento pelo CS evita a superlotação dos hospitais, falando sobre a absorção da demanda de maneira racionalizada e resolutiva.

Das falas das técnicas 1 e 2 pudemos apreender a seguinte categoria: 0 Serviço deve realizar ações de prevenção e educação. A partir dessas considerações estabelecem uma critica à atuação real. Como exemplo:

"A bem da verdade, ele deveria fazer o papel de medicina preventiva, fazer a prevenção de doenças, eu acho, vacinação, atendimento à gestante, atendimento ao idoso... A gente vê, em vez de ser curativo, ah, preventivo, é mais na área curativa, né? A gente faz também o trabalho preventivo, aquele que dá... A gente consegue fazer um trabalho nessa área só que não dá, porque acho que pela própria realidade que a gente vive na saúde..." (Técnica 1)

Em seu discurso observamos que ela não separa a prevenção da cura e sim fala a respeito da prioridade do trabalho com grupos de risco enquanto medida de prevenção (secundária), atividade que, no início do trabalho dos CS, caberia prioritariamente, às auxiliares. Os CS, anteriormente, executavam estas atividades, e, embora houvesse 0 atendimento à demanda, acreditamos que a mesma não 
empurrava as portas do Serviço, como ocorre atualmente. Mudou o quadro nosológico, ou mudaram as disponibilidades do CS?

A outra técnica de enfermagem (2) manifesta-se de maneira semelhante, ressaltando em sua fala o papel do Serviço em promover a Educação e autonomia das pessoas. Faz uma crítica às práticas do Serviço:

"Agora eu observo, eu trabalho aqui há cinco anos... A gente acaba muito limitado nas ações de prevenção. Então a gente acaba se tornando um centro de doença, né, a gente acaba cuidando de quem tá doente, muito mais do que cuidando pras pessoas não ficarem doentes... E acaba não fazendo nosso papel primordial... Como fazer uma pré- escola..." (Técnica 2)

Coloca que tem visto no Serviço pessoas com doenças graves. Cita o câncer, o que em princípio denota um CS mais resolutivo e porta de entrada, e ao invés de ver de forma positiva esse fato, citado como exemplo, ressente-se da falta de outras ações, e da pouca organização realizá-las. Reportando-se à própria escala de trabalho das auxiliares, que a seu ver poderia propiciar uma mudança de lógica na assistência, dá um exemplo de como as ações externas ao CS poderiam tornar-se viáveis, como exemplo, por meio de uma mudança nas atividades propostas para as auxiliares.

Duas das auxiliares ( 2 e 4) falam das finalidades do Serviço de forma breve e além das ações de educação e prevenção dão ênfase à possibilidade de: Atender as pessoas em local próximo de suas casas.

O princípio da regionalização figura, explicitamente, apenas nas falas tal como na de uma das enfermeiras (2).

Uma das auxiliares do grupo das contratadas, como auxiliares de saúde, tem uma representação das finalidades do Serviço próxima a de um dos médicos e 
como veremos posteriormente, das ACD, ou seja: A finalidade do Serviço é atender os mais carentes (sem convênio):

"Bom, eu acho assim, se a pessoa não tem um tipo de convênio, né? Então o centro de saúde tá pra ajudar a população, né? Então as pessoas vêm no CS pra ser atendido". (auxiliar 1)

Parece interessante observar que essa profissional, faz parte da população do bairro. Por não ter convênio é usuária do Centro de Saúde e do SUS. Apresenta, como um dos médicos, de outra origem social, e argumentação de clara matriz neoliberal, concepção que, certamente, não foi veiculada em sua formação como auxiliar e nem mesmo no Projeto Larga Escala e que pode ser originária do senso comum. Ou seja, para a população, o convênio, ou seguro saúde é um bem de consumo, portanto quem não o possui é carente.

\section{Auxiliares de Consultório Dentário}

Do discurso das duas auxiliares da área pudemos apreender a categoria: A finalidade do Serviço é atender pessoas sem convênio médico.

Ressaltam em suas falas que, dado o quadro recessivo do país o Serviço é cada vez mais necessário:

"Referência para as pessoas que tá precisando, que tá sem convênio médico, essas, que hoje a recessão tá grande, né, então o Serviço tá aqui pra isso" (ACD)

"Eu acho que é pra atender à população mais carente, que não tem convênio médico, e que não pode tá pagando..." (THD) 
É interessante observar nessas falas que, em primeira instância, elas são relativas ao atendimento, de modo geral, visto que não tem sido tradição dos convênios, em Campinas, prestarem atendimento odontológico. Desse modo a expressão das finalidades é dada pelo conjunto de ações realizadas pelo Serviço. 


\section{O Funcionamento do SUS}

Com relação ao tema SUS, durante a entrevista a questão relativa ao funcionamento do Sistema só era formulada após verificarmos se o entrevistado conhecia o assunto. Cabe ressaltar que, nas entrevistas padrão, tratamos do tema Reforma Sanitária, não compreendido pelas entrevistadas, o que fez com que no roteiro final mantivéssemos apenas SUS. Notamos que, apesar disso, alguns dos profissionais tiveram dificuldades em discorrer sobre o tema, comentando a própria insegurança. Houve recusa em responder por parte de uma auxiliar de consultório dentário, alegando não conhecer o assunto, embora só um deles (médico) informasse não compreender o significado da sigla. Ele se dispôs a comentar o Sistema, após uma explicação simples. Tal como em relação à finalidade do CS, o padrão de representações aqui não apresentou relação com a escolaridade, e sim com um maior ou menor conhecimento das propostas para o SUS, o que tem a ver com a vivência e o aprendizado em Saúde Pública. Deste modo destacamos como de maior contribuição o que disse grande parte dos docentes (com formação em Saúde Pública), e o parecer dos coordenadores e das auxiliares de enfermagem.

Para trabalhar com o material empírico na construção das categorias de análise tínhamos inicialmente, por parte dos entrevistados, que o Sistema funciona, não funciona, ou funciona parcialmente em certos locais. A partir desse dado inicial, agrupamos as falas, trabalhando, em seqüência, com os argumentos acerca do funcionamento do SUS. 


\section{Profissionais de Nível Superior}

\section{Docentes}

Durante a entrevista, quando falam sobre o SUS, os professores com formação em Saúde Pública, descrevem os inúmeros aspectos do Sistema com muita fluência, como se a entrevistadora estivesse recebendo uma aula sobre políticas públicas de Saúde no país, ou se fosse uma interlocutora para discussão mais aprofundada. Notamos um empolgado interesse pelo assunto. Alguns responsabilizam o Estado pelo não funcionamento do Sistema, ou fazem menção ao funcionamento em alguns locais. De suas falas pudemos apreender as seguintes categorias empiricas:

\section{O SUS não funciona.}

Os docentes que assim se manifestaram ativeram-se às principais diretrizes do SUS e aos efeitos das propostas teóricas de assistência à Saúde.

Ao falarem sobre as causas do não funcionamento do Sistema, os professores de fisioterapia e enfermagem responsabilizam o Estado pela falta de vontade política para fazê-lo funcionar. O docente de fisioterapia não aprofunda o debate. Já a professora de enfermagem elabora maior análise, comentando que as inúmeras dificuldades são decorrentes dos aspectos de custo do Sistema, tais como malversação de recursos, falta de fiscalização e problemas de financiamento. Ressalta que, apesar de todas as dificuldades apontadas, a qualidade dos profissionais de Saúde com atuação no SUS, ou seja, os que estão na "trincheira" 
são bons. Mais uma vez, dentre as inúmeras expressões tais como "campanha" e outras, temos um jargão militar, que a nosso ver não tem nenhuma pretensão autoritária. A professora, ao que parece, emprega o termo trincheira a partir da leitura de que o trabalho em Saúde Pública no país quer dizer (ser) "guerra".

Em sua fala aponta, ainda, o fato de o Sistema "existir" como diretriz, e não de forma concreta. Exemplifica comentando o SUS formal, como utopia dadas as dificuldades para sua implementação no país, como um todo. Há locais em que não está implementado. Vemos em sua fala certa ênfase ao acesso da população à Saúde, como o objetivo maior a ser alcançado

"O SUS é uma utopia. Porque em muitos locais não chegou a ser questionado. Porque é um serviço mal pago... mal visto pela população... Ele não pode , não vai dar conta de ser implantado. De repente ele pode chegar bem perto, né, de ter esse acesso da população". (Docente de enfermagem)

A professora de farmácia coloca que o SUS é um sistema em construção e que o momento vivido é de transição. Assim, a maior parte das críticas ao Sistema advêm do fato de as pessoas o encararem como etapa final de um processo iniciado na concepção. Seu raciocínio tenciona conferir maior credibilidade ao Sistema, pois, é preciso ver o SUS não como 'produto' mas 'processo'. Caso contrário é facilmente desqualificado, a partir de qualquer sinal de mal funcionamento, o que não contribui para sua consolidação.

Acrescenta às suas considerações acerca das causas do mal funcionamento a dificuldade de financiamento e o descaso estatal com a alocação de verbas para 0 Sistema. Segundo ela, outra das dificuldades é dada pela falta de controle social e de organização por parte dos trabalhadores de Saúde e da população. 
Também considerando o SUS como perspectiva de acesso da população à Saúde, a professora de nutrição enfatiza que a universalização e eqüidade dentre as outras diretrizes da Constituição de 1988 são inexeqüiveis, dado um quadro de realidade em que há sucateamento da rede de serviços de saúde e outras "misérias" decorrentes do quadro político e social.

“No papel os principios são os mais louváveis... Ocorre que quando você se depara com a realidade há um descompasso aí enorme... Eu não acho que é falta de vontade política eu acho que é um problema estrutural..."(Docente de Nutrição)

Para subsidiar essa afirmação faz uma retomada do descaso do país com as Políticas Sociais, partindo da privatização da Saúde pós golpe de 64 , que acarretou conseqüências sentidas nos dias atuais. Para ela, a solução de um problema antigo é difícil, para o Estado. Define, como forma de elucidar sua argumentação, o papel e as posições do Estado brasileiro. Assim:

"Por que não tem vontade política?... Não, você tem que examinar toda a trajetória, né? Ele age no sentido de não atender às demandas da população... não de desenvolver uma democracia... aqui (colocando anteriormente como contraponto o estado de bem-estar) ... ele (o Estado) não consegue dar conta disso ... O Estado acaba se encaminhando muito mais na direção de assumir, olha não temos mesmo condição vamos, vamos abrir cada vez mais pro setor privado ... Acho que é uma herança de trinta anos, que atualmente... o Estado não tem condição de assumir isso.'(Docente de nutrição)

A professora de terapia ocupacional coloca o não-funcionamento do Sistema como decorrente da "tendência neoliberal", dando ênfase ao próprio sofrimento, por não enxergar alternativas para tal estado de coisas: 
"Não (pausa)...Eu acho que existe uma tendência realmente

neoliberal... Que não há interesses em investir no sistema Público, fico preocupada e sofro de novo por agonizar aonde essas coisas vão parar, né? Que a tendência de privatização é grande e a gente vai sentindo." (Docente de terapia ocupacional)

Presente nessa fala vemos em primeira instância o pressuposto, já colocado por três das professoras, de que um Sistema em construção enfrenta situações adversas.

Outra categoria empírica obtida das falas de um outro grupo de professores: O SUS funciona parcialmente, ou em alguns locais.

A conformação dessa opinião dá-se a partir de uma perspectiva que leva em conta a racionalidade do Sistema, ou seja, o SUS encarado como provedor de assistência à Saúde. Assim, questões como acesso, efetividade, universalização e controle social, postas anteriormente para justificar o não- funcionamento, não figuram nessas falas.

Para os docentes de medicina, o SUS funciona em Campinas. Ao formularem essa opinião consideram, como a grande parte dos professores, o aspecto de construção do Sistema e as diferentes formas de implementação, dependentes das caracteristicas de municípios e regiões.

Um dos docentes de medicina (1) embasa sua opinião na possibilidade de acesso a recursos tecnológicos oferecidos pelo SUS, tais como serviços de apoio diagnóstico e terapêutico e referência hospitalar. Faz a ressalva de que os profissionais (técnicos) muitas vezes não aproveitam a gama de recursos disponiveis por não terem acesso à informação acerca das possibilidades oferecidas pelo Sistema. 
Já o outro professor da área (medicina 2), coloca que o SUS é um "mosaico" e sua implantação um "processo", enfatizando a história do município de Campinas que investiu na Saúde Pública como situação favorável para a implementação do Sistema. Deste modo:

"No Brasil como um todo eu diria que está mais pra não funcionar que pra funcionar...Agora, pra ficar em Campinas, eu acho que funciona. Tem coisas a serem melhoradas, com certeza. Acho que Campinas perdeu tempo..." (Docente de medicina 2)

A expressão "perda de tempo" é utilizada para classificar o atraso, da Secretaria de Saúde para implementar a gestão semiplena o que, a seu ver, poderia ter sido feito em menor tempo, caso houvesse opção da Secretaria da Saúde. Exemplifica citando o município de Jundiaí, onde esse tipo de gestão existe há mais tempo e, na sua opinião, o SUS funciona. Coloca ainda a gestão semiplena como a forma mais efetiva de administração do Sistema:

"Agora, hoje , a meu ver, a mais completa tradução do SUS, que a gente tem que brigar, que se inserir nesta luta, é a meu ver a gestão semi plena. Porque não vejo como o município hoje possa falar de Sistema Único se ele fica com a assistência primária..." (Docente de medicina 2)

Refere-se às antigas atribuições dos municípios e ao papel das outras instâncias, tais como as estaduais, na responsabilidade de gerir. Interessante destacar na fala seu posicionamento participativo nas lutas. Embora tenha feito tais colocações, considera que os recursos financeiros (ou a falta deles), seja o grande problema do Sistema, dada a falta de recursos do Ministério da Saúde.

A docente de psicologia considera que o SUS, enquanto proposta, seja bom, e neste fato baseia sua análise acerca do funcionamento parcial, decorrente das 
barreiras enfrentadas pelo Sistema. Dentre elas há falta de recursos financeiros. Comenta as dificuldades vividas no Serviço para realizar a ampliação do espaço físico como um exemplo, embora acredite que o Sistema tenda a melhorar com a gestão semiplena e plena.

O SUS funciona: Apenas a professora de fonoaudiologia faz tal afirmação, o que decorre, a nosso ver de seu conhecimento parcial da questão, fruto, inclusive, do ingresso recente na área da Saúde Pública. Emite tal opinião com base no funcionamento da Clínica de fonoaudiologia da Universidade, conveniada ao Sistema.

\section{Médicos}

Três dos médicos conheciam o "significado" da sigla SUS. O quarto deles, num primeiro momento, manifestou não saber e, portanto, sem condições de explicar, a partir de nossa intervenção, para que relatasse sua vivência em três serviços, dois do SUS e um conveniado, demonstrou disposição em comentar inúmeros aspectos do Sistema.

Com relação às considerações acerca do funcionamento do SUS, obtivemos de todo o segmento, a seguinte categoria: O SUS não funciona.

O clínico ressalta que o plano no papel é bom e que sem ele a situação poderia estar pior, que o Ministério da Saúde não tem verba mas que a 
administração também é ruim; que com os altos custos da medicina, às vezes, se despendem muitos recursos só com a assistência médica.

Já o ginecologista enfatiza que deveria haver um plano intermediário entre o "ninguém vai pagar nada" e o "todo mundo vai pagar tudo" e que os serviços públicos deveriam destinar-se a quem realmente não pudesse pagar. Exemplifica com a PUC e o CS e com as pessoas que têm outro convênio e, mesmo assim, usam o serviço. O que não corresponde à nossa observação da realidade e à análise da demanda ao CS realizada por Martins e Mellin, ${ }^{36}$ quando verificamos que apenas 3\% dos clientes tinham outro convênio. Devemos ressaltar que o hospital da PUC também atende a convênios, dentre eles a Unimed, bastante utilizada em Campinas, e que não conta com rede hospitalar própria.

O profissional comenta haver uma desorientação da população, fazendo com que as pessoas não marquem consulta, ou seja, usam os serviços médicos nas ocasiões em que não se sentem bem, o que sobrecarrega os prontos-socorros. Como forma para resolução de toda essa problemática, sugere a adoção de uma carteira única que faria com que os planos de saúde pudessem reembolsar o SUS, por exemplo. Acha, ainda, que o maior problema é a falta de leitos. Parece que, por questões relativas à sua própria visão de mundo, não concorda com os princípios de universalização da assistência, embora se preocupe com o fato de as pessoas receberem assistência.

"A nivel de plano, não vamos resolver de um dia para outro. Um plano, aquilo que fosse um pouco mais complicado, o governo cobriria. Aquela população que não tivesse condições nenhumas passaria a ser aquela população que não poderia pagar nenhum plano. Abrangeria um Posto de Saúde, uma PUC, é... Quem pudesse pagar um plano um pouco maior, vai selecionando um pouquinho. Teria uma carteira única..."(Ginecologista) 
A idéia da carteira única nasce como forma de facilitar o acesso aos planos e o reembolso do SUS, nas ocasiões em que atendesse clientes conveniados. Assim, urgências seriam atendidas em qualquer local, e as consultas deveriam ser marcadas sempre para um mesmo local. Disse que não se consegue remunerar os prontos-socorros adequadamente, mas que os hospitais poderiam atender os SUSdependentes se houvesse um acordo de pagamento sem defasagem entre a prestação da assistência e o reembolso. Também em sua fala fica patente que o SUS arcaria com os custos dos procedimentos mais caros, como já ocorre.

Cabe ressaltarmos que a dificuldade de internação na rede pública tem sido um dos maiores problemas para a implementação do Sistema em Campinas, município que recebe inúmeros pacientes de cidades vizinhas, os que não contam com hospitais. O que se dá, tanto pela falta de leitos públicos, como pelo fato de algumas instituições terem recusado assinar convênio com o SUS.

A psiquiatra não justifica sua opinião, embora ressalte que o sistema tenda a melhorar com a gestão semiplena.

Outra das profissionais do grupo (pediatra) refere-se ao SUS, atendo-se ao aspecto da hierarquização. Para ela, o Sistema não funciona dado os problemas decorrentes da falta de contra-referência de pacientes e da recusa de alguns serviços públicos, dentre os quais o Hospital das Clínicas da UNICAMP, em atender encaminhamentos da rede básica. Não comenta quaisquer outros aspectos do Sistema.

Nesse segmento de profissionais observamos mais uma vez presente a concepção neoliberal de prestação de assistência, ou mesmo posições de que o Estado tem poucos recursos em decorrência direta do alto custo da medicina e não da falta de investimentos em políticas sociais. Ou opiniões mais simples de que o 
Sistema não funciona por que não existe contra-referência ou adesão do hospital da UNICAMP, que recusa clientes, ou não discussão de motivos, caso de uma das profissionais. Aqui o princípio de universalização é discutido, embora às avessas, ou seja, na contramão das diretrizes do SUS.

\section{Dentistas}

A partir das falas das dentistas acerca do funcionamento do SUS, apreendemos a seguinte categoria: O SUS tem falhas.

Seus comentários sobre o tema são bastante breves. Uma delas (dentista 1) cita os problemas de financiamento e da insuficiencia de repasse de verbas para o município. Enfatiza ainda a falta de médicos, decorrente principalmente dos baixos salários pagos a esses profissionais, o que acarreta problemas de falta de atendimento para a população e alto tempo de espera nas consultas.

A nosso ver, a opinião da profissional tem origem no senso comum, ou seja, já que o modelo é médico-centrado, se esse profissional ganhasse bem e estivesse em maior número nos serviços a situação seria resolvida. Não figuram, em sua análise, outras questões sobre o Sistema e mesmo $\circ$ trabalho dos outros profissionais.

A outra das dentistas (2) considera que o Sistema, se concebido como tal deve se constituir em uma boa alternativa, embora apresente falhas, dizendo não ter subsidios para apontá-las. 
De forma semelhante, também as profissionais auxiliares da área não conseguiram comentar a questão ou o fizeram de forma simplificada, como se tais reflexões não fizessem parte do seu cotidiano; ou veiculando concepções advindas do senso comum como falta de médicos e a má remuneração dos profissionais, a nosso ver conseqüência e não causa.

\section{Enfermeiras}

Da fala de uma das profissionais acerca do funcionamento do SUS obtivemos a seguinte categoria: O SUS funciona em Campinas.

A enfermeira (1) considera, dada a sua experiência pessoal e familiar no interior do Estado, que, em Campinas haja mais recursos financeiros para a Saúde, embora não comente as razões para tal.

Para a outra profissional (enfermeira 2): O SUS não funciona.

Antes de comentar o Sistema ressalva sua pouca experiência na área, o que, de acordo com ela, poderia prejudicar o conteúdo da análise, centrando a fala na dificuldade de acesso da população ao atendimento nos CS, principalmente nos serviços mais periféricos, o que sobrecarrega os outros niveis do Sistema. Coloca ainda que para a população o SUS trouxe poucos ganhos. Deste modo:

“...Você tem as pessoas e tudo, mas ... Não é suficiente. Tem ainda muito o que fazer... pelo SUS. Tanto que você vê , aqui (no CS Integração) ainda tem médico, você acha tudo, mas se você vai pros. bairros menos, mais afastados, mais carentes... A pessoa chega lá, você é obrigada a chamar a ambulância porque você não resolve o problema dela... Por mais simples que seja, você não tem uma equipe preparada pra atender àquela população. 


\section{Então acaba superlotando os outros niveis. Então você tem num lugar e na maioria, onde precisa, você não tem". (Enfermeira 2)}

Esta profissional elabora as considerações respaldada, unicamente, nos dados da realidade da prestação de assistência à Saúde em bairros mais periféricos, nos quais uma das maiores dificuldades tem sido a fixação de médicos e a garantia de equipes completas. Em sua fala está implícita a compreensão da necessidade de acesso da clientela e de hierarquização do Sistema.

\section{Coordenadores}

A coordenadora acadêmica considera que: O SUS funciona em Campinas.

Tal como alguns profissionais, compara o município a outros, considerando que, em Campinas, os princípios básicos do SUS, tais como a descentralização administrativa, a municipalização e a hierarquização estejam implementados enfatizando a tendência de melhora a partir da gestão semiplena.

Já o coordenador administrativo afirma que: O SUS não funciona.

Como forma de justificar, coloca que o Sistema vivenciado não funciona. Parte do princípio de que, em sentido geral (formal), o SUS existe em um contexto de grandes dificuldades, relativas ao acesso aos serviços de atenção à Saúde, às políticas de âmbito mais geral, como a de medicamentos e de Recursos Humanos Exemplifica citando os baixos salários dos trabalhadores e a falta de investimentos em educação continuada. Dentre as dificuldades do municipio, está a falta de 
descentralização de recursos capaz de permitir uma maior flexibilidade das ações. A título de exemplo trazemos sua fala:

"A gente está descentralizando, mas a gente não tem acesso a pequenas coisas, por exemplo à reforma no Centro de Saúde. Existe uma descentralização de trabalho, de ações, mas não de poder mesmo. De recursos..." (Coordenador administrativo)

Prossegue de forma bastante enfática:

"Quando falo em recursos, falo em pessoal, falo em dinheiro. Quando falo em dinheiro, falo em exames, internação. Porque se tem uma Central de Vagas (para leitos) e o paciente está aqui... Ele, no sistema privado, essa vaga seria obtida na hora. Precisa mudar essa forma de ser..."

Em sua crítica ao Sistema observa que os hospitais conveniados não cumprem seus deveres junto ao SUS, o que dificulta o acesso dos clientes:

"Saber assim que o hospital da PUC, um hospital que se diz instituição filantrópica, Hospital Universitário, ganha como hospital universitário. Saber que o paciente nosso foi encaminhado, que chega no PS (pronto-socorro) e a pessoa pergunta: "Tem Unimed? Pode passar". Se tem algum aluno nosso ele consegue atendimento".

Continua citando as dificuldades de fiscalização do SUS com relação aos serviços e enfatiza que, em algumas cidades, há outra lógica de organização do Sistema. Centrando sua fala na organização popular, ou na falta dela:

"Algumas cidades conseguem essas coisas da participação das pessoas, não só na questão, Saúde, mas na politica geral mesmo, até no orçamento...". (Coordenador administrativo)

Argumenta, como em suas falas anteriores, que a Saúde não pode ser isolada das outras secretarias, e manifesta esperança de que a situação melhore com a implementação da gestão semiplena. 
Parodiando um dos nossos docentes, podemos dizer que as representações desses profissionais de nivel superior também conformam um mosaico, no qual vimos pessoas com representações próximas das populares do senso comum, originadas, a nosso ver do desconhecimento da dimensão teórico-conceitual do Sistema e outros profissionais, cuja leitura é semelhante à das diversas correntes de pensamento da Reforma Sanitária, não querendo dizer com isso que eles se aliam automaticamente a uma dessas correntes. Assim, acreditamos ter podido acompanhar um certo olhar, expresso na fala. Nesse olhar, alguns focam a questão formal-legal, outros se atêm ao real funcionamento do SUS, partindo de sua experiência cotidiana; outros ainda, caso de um dos médicos, mostram uma clara visão de conformação ao Estado neoliberal, que se responsabiliza, apenas pela Saúde dos excluídos. 


\section{Profissionais de Nível Médio}

\section{Auxiliares de Enfermagem}

Todas as profissionais desse segmento demonstraram conhecer o significado da sigla SUS. A partir de suas falas, acerca do funcionamento do Sistema, obtivemos a seguinte categoria: O SUS não funciona.

Para justificar sua opinião, uma das técnicas (1) faz referência à prestação de atendimento nos três niveis da atenção, considerando a hierarquização, que denomina "atendimento completo", que funciona com muitas dificuldades

Uma das auxiliares (2) considera como dificuldade o acesso da população ao atendimento médico. Exemplifica com a falta de vagas para consultas e para exames mais complexos como, por exemplo, ultra-sonografias. Critica o fato de "outros médicos", ou seja, de outros níveis da rede hierarquizada, não utilizarem o sistema de contra-referência para o CS. Estabelece o seguinte comentário, citando o município de Campinas: "Eu não sei como está lá fora, mas (aqui) está meio devagar".

Outra delas (auxiliar 4), discutindo as dificuldades de acesso da população, ressalta a falta de leitos para internação de pacientes atendidos pelos CS (SUS). Aponta ainda, a insuficiência dos meios de transporte para pacientes do Serviço.

A outra das técnicas (2) elabora sua fala partindo das dificuldades derivadas da falta de recursos financeiros para atender ao princípio do Direito à Saúde. Além disso comenta a malversação dos recursos públicos: 
" Da maneira como está gerenciado eu acredito que não... O SUS em que todas as pessoas têm direito ao atendimento. Concordo que todo mundo tem. Mas fica muito dificil, né?... Por exemplo, a quantidade de pessoas que a gente tem e a quantidade de verba que a gente tem pra suprir o atendimento dessas pessoas é incompativel, né? Outra coisa é que a grande corrupção que a gente vê na Saúde, né, o dinheiro se escoando pela previdência, e acaba não vindo parar onde deveria. Então talvez um gerenciamento melhor do dinheiro..." (Técnica 2)

Continua explicando que, apesar de não haver aumento do montante de recursos, a gestão semiplena possibilita um melhor gerenciamento. Segue abordando o problema dos convênios médicos:

"Um outro problema que a gente enfrenta (nós o SUS), é que os convênios médicos cobram horrores dos pacientes, né, e muitas vezes não cobrem uma série de exames... A consulta é feita no consultório por convênio, mas o exame acaba sendo feito no SUS. Sobrecarrega o Sistema..." (Técnica 2)

Em sua fala prossegue comentando proposta, elaborada por um deputado, de quem não lembra o nome, de que os convênios deveriam reembolsar o SUS por esses atendimentos, o que a seu ver resolveria parte do problema.

Para a auxiliar 1, os problemas do SUS são decorrentes da falta de médicos (dificuldade de acesso), enfatizando que os que recorrem ao Sistema não contam com nenhum outro recurso tais como a medicina privada e os convênios.

"Às vezes as pessoas precisam usar o SuS e acho que não está sendo tão bom ficar na fila, não tem médico, tem gente que não tem condições de pagar uma consulta particular, ou até mesmo um convênio". (Auxiliar 1)

A auxiliar 3 também ressalta as dificuldades de acesso, cita a demora e também o fato de os pacientes serem "mandados" de um lugar para outro, em decorrência do grande número de atendimentos e diante da insuficiência de recursos. 
De forma diversa das auxiliares de consultório dentário e de alguns dos profissionais de nível superior, nas opiniōes das auxiliares pudemos apreender o conhecimento da universalização, traduzida como Direito à Saúde. A partir dela questionam as dificuldades de acesso ao atendimento médico, exames, transporte e leitos. Ainda que, para grande parte delas o CS devesse realizar, prioritariamente ações preventivas e educativas, na discussão dos princípios o SUS figura o conceito da atenção Integral á Saúde. Pensamos então que, ao falarem das ações a serem executadas pelo Serviço refletiam sobre as possibilidades do CS e, principalmente, a propósito de próprias possibilidades de participação mais ativa nas ações de prevenção e educação o que, necessariamente, não cabe aos médicos.

\section{Auxiliares de Consultório Dentário}

A auxiliar (ACD) não emitiu opinião acerca do funcionamento do SUS justificando não saber responder.

Para a técnica (THD), o Sistema: Funciona mal.

Como forma de justificar sua opinião elabora um comentário breve sobre a falta de verbas destinadas aos municípios. 


\section{O Serviço de Saúde utilizado}

A maior parte dos profissionais, de forma independente da escolaridade, tem convênio médico e utiliza esse tipo de serviço. Alguns fazem uso do atendimento de profissionais do serviço público pois conhecem seu trabalho e a boa qualidade. Poucos, por questão de coerência, usam o SUS, embora saibam do acesso diferenciado em relação ao comum da população.

No caso dos docentes, a Universidade não arca com nenhum custo do convênio. Faz, apenas, um contrato global entre a Unimed (convênio) e os professores e funcionários, o que lhes dá a vantagem de não assinar contrato privado. Este é usualmente feito após triagem médica na qual, invariavelmente, em decorrência direta do exame médico, surgem diversos óbices nos contratos. Assim, os docentes pagam o custo total do convênio, com desconto mensal na folha de vencimentos. Cabe ressaltar que o "convênio médico e odontológico" pago integralmente pela Universidade é reivindicação constante por parte dos trabalhadores, por meio das associações de docentes e funcionários.

Já o convênio entre a Prefeitura Municipal e a Unimed é parcialmente subsidiado. O subsidio varia de acordo com o ganho do trabalhador, entre $33 \%$ e $66 \%$ do custo do plano, e o ingresso é facultativo. O convênio, também nesse caso, foi reivindicado pelo Sindicato dos funcionários municipais. Interessante destacar a oposição dos trabalhadores da Secretaria de Saúde. No relatório final da II Conferência Municipal de Saúde, ${ }^{15}$ ocorrida em 1991, são recomendados "mecanismos graduais" de rompimento do convênio Prefeitura Municipal/Unimed 
dada a defesa, veemente, no dizer de Campos, ${ }^{11}$ por parte daqueles da saúde, do emprego de recursos no SUS.

Para análise das falas relativas ao tema em questão trabalhamos primeiramente, com o tipo de serviço utilizado, posteriormente com os motivos para uso dos serviços de Saúde.

\section{Profissionais de Nivel Superior}

\section{Docentes}

Com relação ao serviço de Saúde usados pelos professores obtivemos as seguintes categorias: Utilizam serviços do SUS.

Dois dos docentes, uma do curso de farmácia e o outro de Medicina (docente 1), colocam o uso do SUS como uma opção de cunho ideológico fruto de coerência:

"Mas hoje eu tenho um plano de Saúde que eu relutei muito em ter, né. Nunca fiz a Unimed, quando a PUC fez porque eu achava uma contradição. Tive uma dificuldade muito grande. Eu sou conselheira no Conselho Regional de Farmácia...obrigatoriamente, o conselho é obrigado a dar o convênio. Então...desde o ano passado eu tenho o convênio pra mim e pra minha filha. Eu não, nunca usei, nunca usei. A minha filha, todas as vezes que ela precisou, eu usei esse serviço (Integração)". (Docente de farmácia)

A professora prossegue comentando que tem pensado, por exemplo, que se precisar ligar para um pediatra à noite, este não existe, o que se constitui em um problema, mas que confia no Serviço. 
O docente de medicina(1) coloca:

"Ai é uma coisa, meus quatro filhos nasceram no Serviço Público, em hospitais públicos.... É tem até uma discussão meio doméstica , assim, porque a gente não tem um convênio, porque não faz um seguro...e eu me bato lá, ferrenhamente, que é uma posição ideológica, eu não tenho e eles querem ter. Claro que eventualmente, até por ser médico... Tem ai uma questão, na minha corporação que às vezes isso até fica facilitado" (Docente de medicina 2)

Das falas dos docentes que usam o SUS podemos também apreender que essa utilização dá-se em locais que conhecem e confiam ou por meio de profissionais também já conhecidos e confiáveis.

Duas outras profissionais do segmento: Utilizam profissionais que atuam em serviços do SUS.

A professora de enfermagem utiliza os serviços dos profissionais que atuam em um CS em que trabalha e, seus familiares usam serviços de convênio. Já a docente de nutrição utiliza serviços profissionais de pessoas vinculadas aos serviços públicos, embora às vezes pague por eles nas ocasiões em que se necessita atendimento médico em consultório (raras, segundo ela).

Os outros professores: Utilizam o convênio, ou serviços privados.

A professora de psicologia que normalmente utiliza o convênio, cita o uso do SUS, circunstancialmente, para pessoa da família, e o fato de ter sido bem atendida. Todos os outros docentes utilizam o convênio ou recorrem a amigos (docente medicina 1).

A professora de terapia ocupacional manifesta-se de maneira oposta à dos docentes de medicina (1) e farmácia, com o seguinte comentário: 
“ Eu não uso o serviço público a não ser na vacinação das crianças (riso), até o mês passado. A gente usa a Unimed". (Docente de terapia ocupacional)

No "mês passado" (aí citado) ocorreram graves reações vacinais durante o primeiro dia da campanha de vacinação contra a meningite, organizada pela Secretaria Municipal de Saúde, o que representou situação de calamidade pública.

\section{Médicos}

Com relação ao uso de serviços verificamos que todos os médicos: Utilizam a Unimed.

Dentre eles, apenas a psiquiatra tem, exclusivamente, trabalho assalariado. Os outros profissionais possuem mais de uma atividade assalariada e mantêm consultório. O clínico e o ginecologista falam sobre o fato de pertencerem à cooperativa médica (Unimed):

"Como estou ligado à Unimed, sou cooperado. Então tenho plano de Saúde da Unimed, mas se no geral, quando a consulta é de rotina a gente usa o sistema de consultas nos consultórios particulares, que têm convênio ... Quando é assim um caso de internação, geralmente eu tenho usado mais o hospital da PUC. Assim, usando a Unimed, acho que não é um direito meu, tendo o convênio médico, usar o SUS". (Clínico)

A utilização da PUC nos casos de maior necessidade, a nosso ver baseia-se na confiança e na facilidade do acesso. Caso semelhante é citado pela pediatra:

"Bom, a minha familia tem convênio médico, então, normalmente a gente utiliza o convênio médico, mas como tem ligação com a PUC e eu tenho 
confiança em vários colegas de lá, algumas vezes eles utilizam o serviço da PUC também." (Pediatra).

A psiquiatra ri bastante ao dizer que usa a Unimed.

\section{Dentistas}

Uma das profissionais (dentista 1): Utiliza o convênio com a Unimed. Comenta ter feito convênio ao ingressar na Secretaria da Saúde

A outra profissional (dentista 2) não comenta quê serviço usa sistematicamente, e se tem ou não convênio. Faz questão de ressaltar que seu filho utiliza o CS Integração em consultas com uma dada pediatra e uma dada dentista, por ter plena confiança nas profissionais (não para fazer economia).

\section{Enfermeiras}

Uma das profissionais (enfermeira 2) utiliza, em caso de necessidade:0 médico de familia.

Faz referência ao fato de usar o médico da família, ainda comum no interior de Minas, e não ter precisado usar serviços profissionais em Campinas. Já a outra profissional (enfermeira 1) Utiliza o Centro de Saúde e a Unimed. 
Comenta ter convênio com a Unimed e o fato de seu filho utilizá-lo no municipio em que reside (próximo a Campinas). Ressalta usar o CS, por ter plena confiança nos profissionais do Serviço.

\section{Coordenadores}

Os dois coordenadores utilizam: Convênio médico e serviços do SUS.

A coordenadora acadêmica considera que o convênio possui custo bastante alto (a PUC não subsidia), e que sua familia faz uso do convênio dadas as dificuldades de acesso ao atendimento via SUS. Ressalta ainda, utilizar o CS em casos de imunização e outros, citados como exemplo. Para atendimento com profissionais especificos, o uso do SUS ocorre eventualmente, sempre após contato prévio com o profissional, o que implica garantia de acesso.

Já o coordenador administrativo comenta que sua filha tem prontuário num CS e que, durante o dia, está matriculada em uma creche pública. Assim, como as outras crianças, se sujeita às normas da instituição. Embora diga que há também um pediatra do convênio que a acompanha e que a filha recebe, em serviços particulares, as vacinas que deveriam estar disponiveis a todos os que se utilizam da rede pública. Expressa-se da seguinte forma:

"Nossa, eu tenho que dar uma resposta agora, mas eu não tenho muita. Para vacinações, em geral minha filha usa o serviço público, o pediatra do SUS e tem também o médico que a acompanha, do convênio, mas ( pausa)... Pediatria, ela tem prontuário no Centro de Saúde. Está numa creche pública, municipal. A gente tem que chegar até 7:00, 7:30, após fica com a roupa dela (em caso de atraso) ... segue as normas do sistema. Vacinas eu dou particular quando acho que deveriam estar disponiveis a todos na rede, por exemplo 


\section{Profissionais de Nível Médio}

\section{Auxiliares de Enfermagem}

Duas das profissionais deste grupo (auxiliar 1 e 4) por não terem convênio: Utilizam o CS e o SUS. Cabe ressaltar o fato de não terem comentado os motivos para não possuir convênio.

Todas as outras profissionais do segmento: Utilizam a Unimed.

Para as duas técnicas e uma das auxiliares (3), o convênio é visto como oportunidade de acesso a um bem de consumo:

"Às vezes a gente usa aqui, mas como a gente teve essa oportunidade de estar pagando um convênio particular, a Unimed. Então a gente usa a Unimed" (Técnica 1)

Para a técnica 2, os serviços oferecidos pelo convênio são melhores que os do SUS:

"Então, minha familia tem convênio, junto com a Unimed... Meu pai há uns anos atrás fez cirurgia pelo SUS, né, foi uma experiência traumatizante.

Foi dai que a gente acabou ficando com a Unimed (risos)" (Técnica 2)

Consideração semelhante também é feita pela auxiliar 3, recém contratada:

"Ora, eu não vou dizer que eu não precisei do SUDS. Toda vida eu usei - SUDS, agora eu tenho a Unimed... Porque daí ... se eu tenho um direito, eu 
tenho mais que desfrutar, eu também pago... Então, na medida do possível, que eu não tenho condição de ir pelo SUS, eu vou pela Unimed, dai que já não fica tirando as vezes de quem precisa do SUS" (Auxiliar 3)

\section{Auxiliares de Cirurgião Dentista}

As duas profissionais dessa área: Utilizam a Unimed.

Uma delas $(A C D)$, paga o convênio por meio da Prefeitura, e a outra utiliza o da empresa em que o marido trabalha, "pois a qualidade do plano é melhor" (THD). 


\section{VI-3 - Aproximação das Práticas- Terceiro eixo}

Para nos aproximarmos das representações das práticas dos profissionais buscamos a interpretação das qualidades e deficiências do Serviço, concebida no cotidiano, pelas quais, podemos apreender aspectos do modelo assistencial e a visão dos sujeitos mais restrita ou mais ampliada, de acordo com a convivência com maior ou menor número de profissionais e com as atividades do dia-a-dia.

\section{As Qualidades do Serviço}

\section{Profissionais de nível superior}

\section{Docentes}

Para alguns docentes, as qualidades do Serviço são originárias da sua organização, assim a análise é determinada por uma leitura do: Modelo Assistencial.

Sob essa ótica as qualidades do Serviço são decorrentes da interdisciplinaridade, boa relação com a população (vínculo), organização 
interna das atividades, satisfação da equipe de trabalho, desenvolvimento de práticas alternativas à "medicalização", divulgação dos dados epidemiológicos e de prestação de assistência nas salas de recepção do CS Parece importante ressaltarmos que esses diversos aspectos são lembrados pelos docentes de enfermagem, medicina ( 1 e 2), nutrição, farmácia e psicologia. De suas falas podemos apreender que conhecem a lógica de funcionamento do Serviço em si mesma o que se dá por serem os mais presentes, há quem ressalte que seu tempo de permanência seja pequeno (nutrição e medicina 2).

Ao nos reportarmos à nossa descrição do funcionamento do CS vemos que, o trabalho de fisioterapia e terapia ocupacional no prédio Castelinho e o fato de a docente de fonoaudiologia não fazer supervisão direta e nem freqüentar o Serviço prejudicam a leitura desses docentes do Serviço como um todo

Além das qualidades inerentes ao CS, a docente de psicologia considera, ainda, que o Serviço seja um bom campo de aprendizagem para os estagiários, diverso da clínica de psicologia:

“... Eu acho muito bom a convivência com outros profissionais que a gente pode desenvolver trabalho interdisciplinar... Aprende a conviver com o diferente... Que o estagiário de psicologia sai mais maduro, mais flexivel... Sai com uma postura... mais ousada, mais arrojada, sabe, e com esse ganho de conhecer a interdisciplinaridade". (Docente de psicologia).

Já o de fisioterapia fala sobre as qualidades do Serviço exclusivamente como campo de estágio para a formação dos alunos. Assim, a qualidade do Centro de Saúde é: Proporcionar boas oportunidades de estágio. Descreve suas práticas docentes a partir dessa consideração: 
"Aqui eu procuro que os alunos tenham uma visão... Explorar mais o lado da relação com a familia, com os problemas locais, com a interferência no processo de Saúde-Doença ...Porque a gente vê que a nível de um tratamento ambulatorial a relação terapeuta-paciente é menor...Aqui a gente vai à casa do paciente, conhece as limitações da família... Então procura dar um pouco mais de visão nisso, sobre os problemas sociais... e como ele pode fazer projeto de atenção a uma comunidade, em que a fisioterapia pode estar inserida nesse contexto". (Docente de fisioterapia)

De fato, todas essas atividades são realizadas, embora pudessem acontecer em qualquer outro CS, pois a inserção seria semelhante. Ao nos reportarmos ao modelo assistencial e à própria inserção no curso de fisioterapia, lembramos que esse grupo tem pouco contato com a equipe instalada no CS. Além disso, por não desenvolver práticas interdisciplinares e ações de vigilância à Saúde, de cunho mais geral, trabalha mais como um serviço de referência. Em decorrência, a representação do docente é originada em suas atividades, não nas vivências do conjunto da prestação de assistência.

Da fala da professora de fonoaudiologia, que não freqüenta o Serviço, pudemos apreender que a qualidade do trabalho está vinculada à: Receptividade da equipe docente.

A professora comenta que alguns docentes têm, inclusive, discutido em sala de aula questões teóricas com os alunos de fonoaudiologia.

A professora de terapia ocupacional parece não ver qualidades no Serviço, além das Boas intenções das pessoas. A partir dessa afirmação faz 0 seguinte comentário

"Não acho que há pessoas bem intencionadas. Agora a questão de recursos materiais e físicos... Esse Serviço fica um pouco mais comprometido agora pela característica da docência - assistência... Acho que é muita gente circulando, o planejamento fica difícil". (Docente terapia ocupacional) 
Faz a ressalva de que fica pouco no CS, pois atende no Castelinho. Fala ainda que sua visão do Serviço é de senso comum, embora coloque que o trabalho que o curso de terapia ocupacional tenta realizar seja bom.

\section{Médicos}

Para todos os médicos: O Serviço é mais qualificado que outros da rede. A qualificação decorre do vínculo do CS com a Universidade. A pediatra dá maior ênfase ao Sistema do que à equipe:

"Eu acho muito bom essa integração da Universidade com o SUS porque há falhas nos dois sistemas e faltam exames que são necessários para os dois, que a gente pode utilizar as duas coisas e das especialidades..." (Pediatra)

E num olhar mais pessoal:

"Eu acho bom o relacionamento que tenho, que a maioria das pessoas têm com o nosso coordenador, eu acho que ele tem, é uma pessoa voltada à parte administrativa, parte de estatisticas, mas é voltada também para a parte de prevenção. Acho importante que ele tenta conversar com as escolas, com as creches, para que a gente faça algo nesse sentido e eu sempre tiro dúvidas quanto à medicina pública. Na Saúde Preventiva, sempre discuto os casos mais graves com ele, e tenho esse retorno e o relacionamento que de modo geral, a gente tem, os médicos têm, a enfermagem com as atendentes é bom". (Pediatra).

Mais uma vez, um dos profissionais desse grupo se refere ao coordenador (administrativo), ou seja à pessoa a que se deve satisfações (representante da Secretaria de Saúde). Ao seu encargo, também, estão as ações de Saúde Pública. 
Vemos ainda que melhores condições de trabalho decorrem da melhor estrutura do CS, dai as derivações para análises mais pessoais "aqui eu me sinto bem".

Esse olhar mais pessoal também está presente nas outras falas, onde figuram possibilidades de discussão de casos, encaminhamento dentro do próprio Serviço, ao psiquiatra e ao ginecologista referem-se principalmente ao profissional psicólogo e à oportunidade de realizar grupos educativos, ressaltada pelo clínico.

\section{Dentistas}

Para a dentista 1, que ressalta não se lembrar de maiores qualidades, a principal delas é ter médico (pediatra e ginecologista) e, em decorrência: 0 atendimento ser bom. Não se refere a outras qualidades, nem à do atendimento odontológico, talvez por não prestar atenção, ou, não gostar de "conversar".

Já a outra profissional (dentista 2) faz uma análise de sua situação pessoal e profissional ressaltando que a qualidade do CS está ligada à: Oportunidade de trabalhar em equipe. Que não ocorre nos consultórios odontológicos, assim:

"Bom... é que eu estou desenvolvendo a profissão que eu escolhi...É um aspecto diferente do consultório... É um aprendizado, porque você está sempre trabalhando com pessoas... então você está tendo conflitos dentro da equipe, conflitos positivos, às vezes negativos..." (Dentista 2)

Exemplifica usando a situação-limite ocorrida durante a primeira campanha de vacinação contra a meningite, já citada por nós anteriormente: 
"Às vezes há situação de limite, como a que a gente passou com a campanha de vacinação... Uma coisa que a gente trabalhou em equipe, foi uma coisa interessante... tirando o lado trágico... e pra gente se posicionar mesmo, e como a gente está em relação à equipe, esse espírito de equipe que deveria e que há... existe". (Dentista 2)

Passados alguns dias, essa profissional fez uma carta de agradecimentos $e$ de elogios à equipe e afixou-a na cozinha do Centro de Saúde, local visível. É interessante ver que algumas pessoas prezam as relações humanas, tirando proveito de certo tipo de vivência, em que há oportunidade de maior participação. Nessa ocasião, ela soube bem captar o estado de impotência e abatimento em que se encontravam os profissionais de Saúde e sentir também a importância do "trabalhador coletivo" para o Serviço.

\section{Enfermeiras}

A primeira das enfermeiras (1) que por ocasião de nossa entrevista, encontrava-se bastante insatisfeita com o trabalho no Serviço, tendo pensado em transferir-se, afirma que o que ainda a mantinha no local era a: Maior qualificação do Serviço. O que a caracteriza é a multidisciplinaridade, que possibilita aprendizado, pessoal e trocas, além do fato de a equipe de auxiliares ser boa.

“...A multidisciplinaridade. Os funcionários, eu acho que a equipe é boa... Eu nunca dei tanto valor como dei agora, conhecendo. É assim, a gente nunca fica parada... E como eu disse que eu gosto dessa parte da Educação, então eu adoro isso, pra mim é importantíssimo. Eu estar convivendo com vocês (da enfermagem), convivendo com a nutrição, convivendo com a TO eu aprendo um monte de coisas e, tento repassar isso". (Enfermeira 1) 
Por exercer atividades de supervisão no projeto Larga Escala teve oportunidade de conhecer outros serviços e, portanto, compará-los ao CS. Para os médicos e uma das dentistas a qualidade do Serviço também é vinculada ao bemestar, enquanto profissional.

A outra enfermeira (2) coloca como qualidade: A proximidade do Serviço da casa das pessoas.

"A proximidade mesmo com a população é bom e é ruim... Não é só bom, tem o lado ruim também. E eu acho também assim, a possibilidade de estar indo na casa das pessoas. E não ver só porque não veio, você veio aqui você tem que ver se está fazendo mesmo." (Enfermeira 2)

De maneira diferente do trabalho no Hospital no CS, mais pela proposta de atuação que pela distância, há possibilidade do trabalho domiciliar. Cabe lembrarmos que em discussão anterior esta profissional falou sobre o "lado ruim" da proximidade do CS com os locais de moradia dos usuários. 


\section{Coordenadores}

A coordenadora acadêmica e o coordenador administrativo, bem como a maior parte dos docentes faz uma leitura mais global do Serviço, comentando aquelas relativas ao:

\section{Modelo Assistencial}

Dentre as qualidades estão os maiores recursos tecnológicos tais como eletrocardiógrafo, colposcópio e equipe de saúde mental. Enfatiza ainda a boa qualidade da equipe, o que o torna referência para os subjacentes da área. Também se refere às informações sobre diagnóstico de Saúde e dados de produção e produtividade expostos no saguão (forma de divulgação dos mesmos), e discutidos com o conselho local, embora faça a ressalva de não haver maior intervenção quanto aos problemas levantados. Aborda ainda a interdisciplinaridade como o diferencial da qualidade. Mantendo coerência com a fala anterior, sua opinião relativa à representação das qualidades baseia-se nos aspectos da docência e da assistência. Faz essa avaliação enfocando os dois lados como uma via de mão dupla, ou seja, a Universidade constrói o Serviço e este constrói a Universidade (enquanto campo das práticas pedagógicas), relacionando essas práticas à qualidade dos serviços prestados á população: 
diversidade de ações de Saúde para a população... Você tem a figura do

fisioterapeuta, do terapeuta ocupacional, da nutricionista e outros profissionais que você não vai encontrar na rede... Eu acho que a população ganha porque ela tem uma oferta maior de serviços... Também como ele tem

esse convênio (entre aspas), entre as duas instituições é um serviço que normalmente não vive falta de recursos materias, que em outros a gente sabe que existe, porque a prefeitura assume grande parte e a PUC complementa..."(Coordenadora acadêmica)

Prossegue exemplificando com a compra de material para curativos (mais diversificados), realizada pela Universidade e reforçando que a presença dela "empurra" o Serviço:

"Eu acho que passa um pouco também, sempre tem aquela idéia de que tem alguém de fora, por um lado que está cobrando, que está sugerindo, que está propondo, e o Serviço acho que consegue se rever um pouco mais. Então acho que é uma troca, porque a Universidade também ganha quando está no

Serviço, porque está acompanhando as coisas que realmente estão acontecendo..."

Faz uma crítica ao isolamento da Universidade:

"Eu acho que a gente, enquanto Universidade, tá assim um pouco atrás do Serviço, nos aspectos de informações que vão chegando e a gente só fica sabendo quando está lá. Isso é terrivel...".(Coordenadora acadêmica)

O coordenador administrativo enfatiza o vínculo da população com o Serviço, a qualidade técnica da equipe e a interdisciplinaridade (relação com a PUC). Em sua fala:

"Acho que tem um aspecto muito legal com a clientela, a própria enfermeira de Paulínia que está aqui reparou que as pessoas voltam... têm uma história no bairro...". (Coordenador administrativo) 


\section{Profissionais de Nível Médio}

\section{Auxiliares de Enfermagem}

Três dessas profissionais, ao se reportarem às qualidades do Serviço, ancoram suas opiniões em aspectos bastante concretos, relacionados com as parcelas do todo do CS. Fazem uma avaliação das distintas áreas. Ressaltamos ainda que apenas uma delas não soube, ou não quis, emitir opinião, dizendo que tudo era bom (auxiliar 1). Dessa forma podemos analisar que sua leitura também é vinculada ao

\section{Modelo Assistencial}

Fazem essa avaliação de forma diversa à dos coordenadores e docentes. São reflexões de caráter mais geral, a partir da concretude das áreas de atendimento. As falas dessas profissionais contêm, a nosso ver, conceitos acerca da eficácia do Serviço, e critérios de avaliação respaldados na suficiência e qualificação dos recursos humanos, recursos materiais e realização de atividades de educação em saúde.

Assim, uma das técnicas (1) vê como "boa" no Serviço a área de imunização. Cita também os atendimentos gerais (inalação, curativos e outros) e odontologia, 
que convivem com outras áreas, a seu ver, deficitárias, fixando-se unicamente na qualidade da assistência prestada.

Duas das auxiliares ( 2 e 4) apontam como bons os programas de acompanhamento de hipertensos e diabéticos e a pediatria, uma delas dando ênfase ao número de médicos, ao grupo de gestantes e ao atendimento em ginecologia:

"Bom, eu acho que ainda falta muita coisa... Ginecologia tá bem. Os outros programas de hipertensão... com andamento muito bom, têm ótimos funcionários, estão fazendo (pausa), dando aulas pros pacientes também, né?

Porque da hipertensão, da diabete eles vão, têm passeio, tem grupo de gestante também com aula, grupo da mulher, também tem a pediatria". (auxiliar. 4)

E, com a mesma lógica de expressão:

"Assim, por exemplo, a quantidade de pediatras, seria até melhor que tivesse mais, porque falta um no periodo noturno, até as 21 horas. No mais, dentro do possivel, a gente está bem. A ginecologia também tem alguns profissionais que são melhores que em outros Centros de Saúde e tem, dentro da ginecologia, a gente tem o que outros CS não têm, que é o colposcópio, aparelho pra estar cauterizando, tudo isso dai a gente tem".

Observamos ainda que duas das profissionais fazem uma leitura mais global do Serviço, próxima à dos coordenadores e docentes. Assim, a técnica de enfermagem (2, contratada pela PUCCAMP), refere-se à integração docenteassistencial, principalmente porque aprende muito com os docentes (fato comentado por uma das enfermeiras). Para ela, no Serviço, a clientela tem acesso a mais recursos, além dos trabalhos nos grupos educativos, principalmente os realizados com adultos, que a seu ver são muito bons. 
De forma bastante interessante, a auxiliar de enfermagem 3, recémcontratada, acredita que a qualidade do Serviço seja a possibilidade de desenvolver trabalho que não dependa das atividades médicas.

"Porque tudo é muito bom aqui. O que eu acho bom mesmo, é o que eu gosto de fazer, são os grupos... Porque você vê o pessoal, às vezes o pessoal vem e procura uma consulta só pra pegar uma receita do remédio dele que acabou, ele vai tirando o lugar de uma pessoa doente, né? E o grupo não é só pra fornecer os remédios, ele também é pra educar, a maneira de comer, né? Do alimento, como as nutricionistas dão. Ah a gente dá sobre o estresse, que hoje é uma doença que todo mundo tem, né? $E$ a gente fala também, tem muitas pessoas que têm pressão alta por um problema familiar, e que ele não tem oportunidade de falar esse problema, assim às vezes nem com o vizinho, e aqui no grupo ele se abre e fala, então é a única brecha que eu acho, é o único espaço que ele tem de estar se comunicando, de tá junto com o grupo que tem a mesma doença dele. Tá, eu gosto muito, por isso que... Eu estou pondo pra mim". (Auxiliar de enfermagem 3)

A possibilidade de receber e dar atenção integral, está contida nessa fala. Mesmo desconhecendo aspectos "teóricos", a profissional captou como bom um modo de trabalhar a saúde das pessoas como ela gostaria de ser tratada. Empatia? Talvez, sensibilidade.

\section{Auxiliares de Consultório Dentário}

As profissionais dessa área acham que as qualidades do Serviço são o número de profissionais (equipe completa) e a qualidade dos profissionais. A primeira delas ancora sua opinião em um contraponto com os outros serviços da rede em que faltam Médicos, mais uma vez centrando sua fala nesse profissional: 
"Ah, eu acho que tá bom, né... O número de profissionais que tem, né , porque tem Posto de Saúde que não tem pediatra, se tem pediatra, não tem clínico, se tem clínico, não tem ginecologista, e tá assim bem distribuído, né , de profissionais". (ACD)

"Eu acho que os profissionais que trabalham aqui são excelentes ... Sem citar assim o doutor, isso eu acho, tanto a enfermagem, quanto os médicos, os dentistas, de um modo geral". (THD)

\section{As Deficiências do Serviço}

\section{Profissionais de Nível Superior}

\section{Docentes}

Uma das categorias obtidas das falas dos docentes e relativas ás deficiências do Centro de Saúde são as: Dificuldades da Universidade relativas ao trabalho docente assistencial.

De forma diversa ao que fizeram ao tratar das qualidades do Serviço, ocasião em que enfocaram prioritariamente o modelo assistencial, a maior parte dos professores se atém às dificuldades da Universidade. Dentre elas as professoras de nutrição e terapia ocupacional falam daquelas relativas ao próprio grupo de professores, com discursos bastante diferenciados, como pudemos observar, e caminhares diferentes. Como exemplo temos a fala da docente de nutrição: 
“... Desde carga horária, problemas bem práticos... não tem definido na PUC uma politica docente assistencial... (após as considerações sobre a estrutura da Universidade e condições de trabalho prossegue). Tudo bem a gente é uma equipe, um grupo, mas existem visões diferentes do que é a Saúde Pública, do que é a interdisciplinaridade. Então a gente não consegue se integrar, e entender da mesma forma..." (Docente de nutrição)

A professora de terapia ocupacional, que não identificou no CS qualidades senão a boa intenção das pessoas, coloca dificuldades de planejamento nas atividades dos cursos envolvidos no projeto:

"Eu acho que a gente tem dificuldades de planejamento... Tem dificuldades de ter uma linguagem comum para fazer esse planejamento interdisciplinar, para estar apreendendo todas as situações do CS. A gente até senta (se reúne), conversa, mas no dia-a-dia essas coisas ficam perdidas porque a gente tem disciplinas para tocar, aí falando mais na docência". (Docente de terapia ocupacional)

Com relação às deficiências em si que, diante de sua opinião acerca da qualidade seriam muitas, a docente faz um comentário muito geral:

"Agora, da assistência eu vejo também alguns desencontros, mas eu fico até preocupada em falar, porque é aquela leitura meio geral, não estou aqui no dia-a-dia."

Três docentes, nutrição, medicina (1) e de fisioterapia citam também as dificuldades de organização causadas pelos diferentes calendários acadêmicos dos cursos.

Os docentes de enfermagem, fisioterapia, medicina (docente 2) e farmácia apontam como principal deficiência do Serviço a falta de: Espaço físico.

Como exemplar trazemos a fala da docente de farmácia: 
"Eu acho que a gente tem um problema sério de espaço físico, né, mas eu não acho que ele é o determinante, o limite é a não-disponibilidade das pessoas, acaba sendo o espaço físico." (Docente de farmácia)

Um docente de medicina relaciona a deficiência com o prejuízo acadêmico para os alunos, dada a falta de salas para o atendimento.

Outras das deficiências apontadas são diretamente relacionáveis a: Questões amplas de organização do serviço.

Dentre elas, destacamos a insuficiência de Recursos Humanos para o atendimento das necessidades da população adstrita:

"Então, um Centro de Saúde que atende 30.000 pessoas, né, e o número de profissionais é pequeno". (Docente de enfermagem)

A alta rotatividade dos médicos é citada pela docente de farmácia como uma dificuldade para a implementação do modelo de assistência farmacêutica:

"Mas existe ainda dificuldades de alguma parte, setores da equipe de terem uma rotatividade muito grande... Por exemplo, quando chega um profissional médico novo no Serviço, né, a gente tem uma rotatividade razoável de médicos. E que ele vem de outro Serviço, e assim: "Olha eu trabalho assim", e o serviço tem que se adaptar... Quem vem tem que vir na perspectiva de se adaptar. Claro que pode trazer elementos novos, vamos colocar em discussão, mas não dá pra gente quebrar o processo de trabalho... Acho que isso é uma questão de modelo... A gente não tem um modelo muito bem definido, em todas as áreas. E repercute isso na minha área. A gente não tem padronização de procedimento ainda. O Serviço que não trabalha com padronização de procedimento eu acho muito falho"..(Docente de farmácia)

Essa alta rotatividade dos médicos é também apontada pelos dois docentes de medicina. Um deles (docente 1) comenta ainda as dificuldades do Estado para a 
implementação de uma boa assistência, criticando a falta de medicamentos e os baixos salários.

A professora de psicologia tem uma opinião derivada de visão bastante particular quanto as formas como se dão as relações de trabalho na equipe. O CS é visto por ela como um conjunto de pessoas que trabalham e se relacionam. Sua principal deficiência é decorrente de: Dificuldades de relacionamento na equipe. Centra sua fala nessa percepção relativa às relações de trabalho no Serviço:

"Ah, por exemplo, um comentário recente de uma pessoa: 'Nossa quanta gente trabalha aqui, e ninguém faz nada?' ... Tem um bando de auxiliares de saúde, então você busca um, busca outro, e não, a coisa não anda... É a demanda, o paciente que fica bravo: 'Por que essas moças ficam tanto tempo na cozinha?' Por que esse médico não chega?" ( Docente de Psicologia)

Trabalhando dentro de uma visão de senso comum, a professora não se atém ao fato das atividades do Serviço serem centradas no trabalho médico. Isto é, toda a equipe de enfermagem trabalha para dar suporte ao trabalho do profissional, salvo raras exceções em que consegue desempenhar trabalho independente. $O$ que se dá nos grupos educativos e nas atividades de atendimento programado para as crianças e adultos, ou mesmo no caso de atendimentos gerais. A professora prossegue em sua fala:

"O pessoal tem muitas queixas do quanto ganha... Então acaba vazando na forma como lida com o Serviço... Acho que necessita de um trabalho institucional... Tem mil nheco - nheco (ruido) de funcionários, sabe grupinhos, um vira a cara para o outro... Você vai pegando as repercussōes disso... falta uma integração...tanto dos funcionários, como do filão Prefeitura e PUC. E aí quem dança primeiro é o paciente... é a demanda ... A recepção nesse sentido pega um embate muito grande...porque é ali, né? Que a população descarrega tudo que está sentindo". (Docente de psicologia) 
Acreditamos que a clientela possa dançar também por isso, mas principalmente pela falta de recursos para o atendimento que gera repressão da demanda, sofrida pelo cliente e pela recepção. Também, por essa lógica de análise, quem mais deve sofrer são os próprios profissionais com vivências tão desagradáveis.

Já a professora de fonoaudiologia refere-se unicamente às dificuldades de realizar trabalho integrado, principalmente nas áreas de pediatria e ginecologia.

Para a professora de fonoaudiologia, a dificuldade centra-se na integração de trabalhos (não se aprofunda no tema), mas em outra ocasião refere-se a dificuldades de relacionamento com os pediatras e a de seus alunos organizarem cursos para as gestantes.

\section{Médicos}

Aqui também a representação das deficiências tem sua origem nas áreas em que atuam, e somente nelas. Assim o clínico, cuja área tem sido a mais prejudicada pela falta de profissionais e rotatividade dos que ingressam, muitas vezes em trabalho temporário ou no espaço entre o término da graduação e o ingresso em curso de residência, coloca a: Alta rotatividade dos médicos.

Parece-nos interessante observar que a insuficiência no número de médicos e a rotatividade da equipe não tenha sido apontada ao comentar-se que o Serviço deve "atender os mais carentes", já que não pode atender todas as pessoas. 
Questão lógica, pois se houvesse mais médicos e equipe mais habituada ao trabalho, mais pessoas seriam atendidas.

Para a pediatra o CS tem uma deficiência comum aos outros Serviços, ou seja: A população não sabe em que ocasião procurar o Serviço. Exemplifica dessa forma:

"Existe uma deficiência que é geral, que é... a orientação da população de quando procurar e não procurar e porque não consegue ser atendida. Então é uma deficiência que está sendo gerada pelo governo em fazerem cobrar do médico, do Centro de Saúde e não cobrar a Saúde de um modo geral, no governo federal, né?". (Pediatra)

Parte do pressuposto da regularização da demanda, fruto talvez da pressão cotidiana sobre os médicos para 0 atendimento. Outra questão patente é que a população reivindique o que considera seus direitos em instâncias que the estejam próximas.

Também cita uma questão interna, decorrente do modelo assistencial que é ocasionada por falta de espaço para discussão entre as áreas, subentendendo-se o trabalho de enfermagem e nutrição, também realizado com crianças.

"A gente tem uma falta de espaço importante para que haja essa troca de idéias com as outras áreas; que haja atendimento das outras áreas aqui dentro, e uma falha da Pediatria. É isso que a gente está tentando suprir na organização de grupos". (Pediatra)

Também sob o enfoque da demanda para consultas em sua área, o ginecologista cita as falhas da recepção que às vezes coloca muitos atendimentos em um só dia, e apresenta falta de capacidade de triagem aqui denominadas: Falhas da recepção do Serviço. Coloca a questão do seguinte modo: 
"Tem dia que deveria ter uma pessoa um pouco mais tarimbada para poder triar um pouco melhor. A gente vê que às vezes a pessoa chega, fala alguma coisa, chega aqui (no consultório), fala outra. Então essa pessoa numa conversinha de 30 segundos... você tem uma idéia geral do que a pessoa quer... E tem certas coisas que o pessoal vinha às vezes só pra pedir encaminhamento... Elas vêm aqui e querem encaminhamento para oftalmologia... Então elas ficam na fila pra passar pelo médico... A enfermagem faria, uma coisa simples assim". (Ginecologista)

Para a recepção é bastante difícil triar os casos de pessoas que solicitam a consulta, nem é cabível que o faça, cerceando mais uma vez o direito do cliente de encontrar determinado profissional. Também, outro fato a ser considerado é que nos consultórios médicos, provavelmente haja procura do profissional para discussão de um dado encaminhamento e, bastante improvável, que a recepcionista negue o acesso, ou resolva o caso do cliente, embora não estejamos aqui discutindo o papel da equipe de enfermagem, no acompanhamento de certos clientes.

A psiquiatra se reporta tanto às deficiências externas do Serviço (estruturais), como à falta de retaguarda de leitos e de transporte dos pacientes e internas a ele, inexistência de material para a contenção de pacientes e Recursos Humanos capacitados para tal, além de mau relacionamento do coordenador com a equipe de saúde mental. (Não explica o porquê.) 


\section{Dentistas}

Das falas das profissionais da área obtivemos a seguinte categoria: Há deficiências do serviço, não da odontologia.

Assim a dentista 1 coloca as dificuldades dos pacientes em conseguir consultas, aspecto este também enfatizado por nós quando da análise do modelo assistencial:

"A deficiência, eu acho por exemplo que é uma coisa muito ruim... Não da parte odontológica, que a gente não faz o pessoal esperar muito tempo, a gente marca o horário sete e meia pra não vir muito cedo, ficar em fila, essas coisas. Agora eu acho ruim é a parte médica. Fico sabendo que o pessoal chega às cinco da manhã pra conseguir um encaixe de urgência. Sabe, ter de passar aquela coisa de vir de madrugada pra conseguir esse encaixe. Eu não sei como funcionam os médicos. Assim, se é atendimento de urgência ,tal... Não sei se tem como solucionar, mas acho isso muito ruim, ter que ficar logo cedo". (Dentista 1)

$\mathrm{Na}$ fala, fruto do que salta aos olhos, do evidente, as pessoas sofrem por chegar cedo, embora não considere que elas sofram também por muitos outros motivos... Provavelmente, também em decorrência das dificuldades em conseguir acompanhamento por parte de dentistas. A título de exemplo, o setor de odontologia do Serviço, como vimos na descrição do funcionamento do Serviço, abre sua agenda a cada seis meses e destina uma hora do dia para atender urgências, o que contribui para que as pessoas aguardem, também, em suas casas.

A outra dentista (2), também enfoca em princípio o Serviço como um todo e, também com leitura de senso comum, destaca a: Falta de médicos. 
Fala sobre a contínua existência de "vagas" no Serviço, o que para ela se deve aos baixos salários e ao fato do CS significar um rito de passagem para os profissionais recém-formados:

"Vamos dizer profissionais de Saúde, os médicos, os dentistas, às vezes usam a Saúde Pública, não, o emprego público como um estágio, uma passagem... De uma situação de recém-formado ele vai se estabelecer somente nos consultórios." (Dentista 2)

Também ressalta que, diante da crise de mercado, a procura pelo trabalho nos serviços públicos tem aumentado. Fala também das ocasionais faltas de material para o seu trabalho.

\section{Enfermeiras}

Para as duas enfermeiras, a principal deficiência é decorrente da:Falta de espaço físico.

Questão também enfocada pelos docentes. Uma delas destaca que o espaço é ruim e a planta física também (enfermeira 1). A outra acrescenta que há muita gente e muitos alunos. Em decorrência “... um atropela o outro...” (enfermeira 2). Há muita disputa por salas vazias, embora ressalve que "o pessoal" seja muito bom para trabalhar. A enfermeira 1, comenta como aspecto negativo do Serviço a, "centralização do coordenador" e que por causa dessa característica da gerência o trabalho é dificultado: 
"Eu acho que o principal, na minha opinião, é o espaço físico, a planta física e uma melhor organização... O fluxo é muito desorganizado, né, eu acho que precisava ser uma coisa mais organizada, descentralizada, talvez. Eu acho que é muito centralizado no coordenador... É muito centralizador, depende muito dele... as ações, por isso eu acho que precisavam ser mais descentralizadas as ações..." (Enfermeira 1)

\section{Coordenadores}

Para os coordenadores uma grande deficiência é a relacionada com o:

\section{Espaço físico}

A coordenadora acadêmica reforça que a dificuldade se torna maior por haver elementos das duas instituições (PUC e Prefeitura), e o coordenador administrativo comenta o prejuizo para as ações de educação em saúde, em grupos, dada a falta de local para essas atividades.

Outro problema levantado pelo profissional é: A pouca intervenção do Serviço em espaços externos (populacionais). Comenta que essa seria uma ação possivel, verificadas as situações de risco. Como exemplo:

“Mapear pequenas áreas, territórios. Por exemplo, a questão da violência. A gente não atende quem chega aqui machucado mas não dá conta de quem está lá fora. Por exemplo, trabalhar com escola, a própria estrutura acadêmica, os cursos de medicina, enfermagem, poderiam fazer".

(Coordenador administrativo)

Outra deficiência apontada pela coordenadora acadêmica é o: Número de profissionais médicos insuficiente para atender às necessidades da população. 
Para formular essa crítica baseou-se no conceito da atenção integral e no pressuposto do CS como porta de entrada do Sistema. Ressaltando ainda que essa, também, é uma dificuldade apontada pela população por meio do "156" (telefone municipal onde as pessoas fazem "queixas" dos serviços públicos).

Os dois coordenadores comentam ainda as: Dificuldades para coletar e utilizar informações epidemiológicas.

Os profissionais, ao discutirem essa temática, usam diferentes formas de análise. Para o coordenador administrativo a deficiência maior é a dificuldade de obtenção de dados de morbidade populacional. Já a coordenadora acadêmica comenta que o Serviço apesar de ter inúmeros dados produzidos e analisados, não os utiliza para transformar o cotidiano e encontrar formas de intervenção:

"Eu acho assim que apesar de serem feitos muitos estudos, levantamentos e diagnósticos, o Serviço ainda não consegue ter propostas de ... em todos os problemas que ele consegue identificar... Então a gente está 'careca' de saber o que precisa, o que a população, a necessidade da população, mas ai não se trabalha assim para dar conta desse perfil de novidades que a área tem, tanto é que da droga, da drogadicção, então, quer dizer, do adolescente, que o Serviço não tem nenhuma intervenção. A questão do idoso, que é uma proposta, né, importante da área, de serviço, também não tem uma coisa programada, então é uma coisa muito viciada, por conta da docência". (Coordenadora acadêmica)

Avaliamos que esses olhares, embora com focos diferentes, têm por base, como dissemos anteriormente, o pressuposto da assistência integral à população, relacionando o Serviço a ela. Também identificamos em suas falas, uma crítica às ações da Universidade. Os dois coordenadores enfocam ainda: As dificuldades internas à estrutura do Serviço.

Elas decorrem das dificuldades de relacionamento na equipe de nivel médio (coordenador administrativo), também apontadas pela professora de 
psicologia. Fala ainda acerca da avaliação de desempenho da equipe e da organização do serviço. Como exemplo, trazemos as falas dos coordenadores:

"A gente tem problemas, altos e baixos, a gente está num baixo. Tem problemas sérios. Primeiro era Nóbrega e Garcia (por ocasião da união das equipes), agora é manhã, tarde e noite Também em Paulínia tem isso, problema manhã, noite. Não é mais a turma da PUC e da Prefeitura... Mas isso a gente tem conversado na reunião geral".(Coordenador administrativo)

"Tem questões internas. Eu acho que o Serviço é um pouco bagunçado (entre aspas) não se consegue ter um nivel muito grande de organização e de acompanhamento dessas atividades. Então eu acho que falta para o Serviço uma proposta... uma proposta de avaliação, quer dizer o Serviço estar, eu já estou colocando isso, mas o serviço é uma coisa de lado, né? (querendo dizer

que é uma proposta pessoal)... Ele está dentro de uma rede de serviços do município, o município também tem essa proposta de... estar avaliando o pessoal, mas o Serviço, já que tem uma Universidade lá dentro também podia ter uma proposta". (Coordenadora acadêmica)

Prossegue delineando proposta de cunho administrativo-organizacional. Revela a falta de um estatuto que regulamente o trabalho no Serviço, principalmente quanto a questões de saidas, desistências e reposições, que apesar de discutidas com a equipe, não são regulamentadas. O coordenador administrativo também coloca o problema de outra forma. Começa elaborando uma crítica à falta de compreensão dos enfermeiros (contratados pela Secretaria da saúde) quanto ao seu papel no Serviço. Na seqüência, prossegue discorrendo sobre os papéis das duas instituições envolvidas no projeto, e o da própria população:

"E a enfermagem tem um papel de relevância para a coordenação do Serviço, para a avaliação técnica, das técnicas... Uma coisa importante é definir o papel... Qual o papel da Prefeitura? A gente tem várias intercorrências, por exemplo, na sexta feira (21/06) a PUC deu greve e não descontou o dia dos seus funcionários. Qual é a posição da Prefeitura? Desconta as horas não trabalhadas e quem assume essas coisas, esse papel é a gerência... Eu acho que seria facilitador se houvesse essa definição. Se não houver... é uma dificuldade para organizar e superar essas deficiências. Mesma coisa a questão salarial. Tem época que a Prefeitura paga melhor, 
agora a PUC paga melhor, existem 4 pessoas que são da PUC. Como a gerência resolve isso?... Outra, participação das pessoas, participação da população. Colocar seus direitos aqui dentro. Elas se relacionam, mas quando são chamadas a participar para organizar o conselho, isso facilitaria muito, tanto, o Serviço porque eles saberiam das nossas dificuldades. É complicado funcionário falar dos problemas da organização do Serviço, porque é a visão dele... A gente tem que ajudar a população para que ela seja representativa, elas têm mais direitos do que exercem, eu acho, por exemplo a questão do espaço, que a discussão não é só com eles. Tem que ser com eles sim, tem que ser com a SAR - Oeste (Secretaria de Ação Regional), tem que ser com a Secretaria (da Saúde). Então as pessoas não conhecem o potencial que elas têm, de levar suas lutas". (Coordenador administrativo)

Da fala desse profissional apreendemos que ele parece ter consciência de que a equipe o tem como representante das instâncias decisivas, como vimos nas falas de alguns médicos, e, de forma crítica, na de uma das enfermeiras, o que não deve ser tarefa fácil. 


\section{Profissionais de Nível Médio}

\section{Auxiliares de Enfermagem}

Apenas uma das auxiliares não vê deficiências no Serviço, em coerência com seu parecer sobre as qualidades (auxiliar 1), para emitir essa opinião: O Serviço não tem deficiências.

Estabelece um contraponto com outros em que estagiou durante o curso de Larga Escala

"Eu acho que é melhor, melhor que muitos em que eu fiz estágios, no, no A.. Eu acho meio ruinzinho." (Auxiliar 1)

Todas as outras profissionais têm uma leitura bastante ampla do Serviço, de forma semelhante à dos coordenadores e de um grupo de docentes e, questão contraditória, de suas supervisoras diretas, as enfermeiras. Assim as deficiências relacionam-se às finalidades e objetivos do CS. As auxiliares 2 e 3 , tal como docentes, coordenadores e enfermeiras, citam o: Espaço físico.

Uma delas (auxiliar 2) descreve com detalhes a situação:

“Deficiências, bom, em primeiro lugar falta de espaço, essa é a maior, é a maior porque eu acho assim, você tem que respeitar a individualidade do paciente, né? E às vezes ele é atendido, ou na sala de reunião, onde há aglomerado, por qualquer motivo, ou numa salinha junto com outras pessoas..." (Auxiliar 2) 
Prossegue justificando os motivos pelos quais o Serviço tornou-se pequeno, enfocando as necessidades de Saúde da população e a integração com a PUC, atribuindo a falta de espaço à ausência de planejamento por parte da Secretaria de Saúde:

"Então, quando se construiu essa planta aqui do Centro de Saúde, foi pensando muito pequeno, foi pensando assim, Garcia, Nobrega e Castelo Branco. Depois não se pensou que a gente teria uma área de cobertura de quase 40.000 pessoas, né? Depois veio a PUC pra cá, que trouxe muitos profissionais que a gente não tinha na época, né? E a PUC veio trazendo muitos profissionais e o espaço ficou de uma carência enorme". (Auxiliar 2)

Já a auxiliar 3 , além da falta de espaço acrescenta às deficiências a: Insuficiência de recursos materiais.

Cita como exemplo o número de saídas para inalação, opinião também presente nas falas da técnica de enfermagem 2, que comenta outras dificuldades quanto a recursos.

"Outra coisa também que é terrível é o que eu falei , de material pra estar trabalhando, de meios pra você estar trabalhando, né isso também, né, por exemplo, medicação, falta né? Material adequado... não tem. Perua para visitar, né, fazer bloqueio. Dizem (eles): 'Ah, não ... a gente vai dar um jeito', mas não dá... Essas coisas que realmente acabam acontecendo na Saúde Pública, né? A falta de verba e tal..."(Técnica 2)

A técnica 1 discorre sobre a falta de médicos e, falando sobre sua atividade na recepção, mostra-se angustiada com o problema:

"Falta de (pausa) profissionais na área médica, clínico geral, principalmente, né? Psiquiatra, por exemplo, nós não temos psiquiatras suficientes pra atender à demanda da região, então eu acho que isso ai é um problema seríssimo... Eu acho que essa angústia não é só minha... Mas de todo mundo, da equipe. Isso ai realmente é estressante, até ao ponto de você

falar pra pessoa procurar outro lugar. Às vezes está precisando do atendimento e ela tem... O pior é que a gente é referéncia na região, né? Além 
da gente não poder atender os daqui, ainda tem os de fora e tem que dar uma resposta, e a gente fica sem condição pra isso". (Técnica 1)

Predominam nas falas da técnica 2 e da auxiliar 4: As dificuldades de gerenciamento e organização, internas e externas ao Serviço.

Assim, a primeira delas reporta-se às escalas de pessoal e ao planejamento das férias:

"Uma dificuldade de organização, dos funcionários, da parte dos recursos humanos. Eu sinto isso muito. Parece que é meio dificil estar controlando férias oficiais... Às vezes eu sinto que algumas áreas ficam... com muitos funcionários, e outras ficam (com poucos), então parece que fica dificil ter uma visão do todo. Eu sei que é bem complexo mesmo, né? Por exemplo, até numa reunião eu comentei, né, a garota, a $C$., que está na recepção está grávida, né. E ela teve até uma crise, outro dia, nervosa, um tempo atrás. E aí eu disse: - Olha, não sei, pra mim, o papel da chefia é tá observando isso, tá sentando (conversando a respeito). 'Olha você tá grávida, tá estressada, você acha que é legal você ficar nesse lugar que é mais estressante ainda? Vamos

tentar, né, acertar as coisas, tentar...' Eu acredito que seria bom se isso acontecesse". (Técnica 1)

Para a auxiliar 4, com o tempo, a Secretaria da Saúde distanciou-se do Serviço, o que acarretou deficiências:

"De estrutura né? Eu acho assim que a gente tem, eu vejo como deficiência, uma separação, assim do Centro de Saúde com a Secretaria da Saúde, por exemplo, que tudo vem através do coordenador, pra gente estar sabendo muitas notícias, comunicação assim. Porque como já fazem... Vai fazer 17 anos que eu trabalho aqui no CS. a gente tinha uma ligação um pouco mais aprofundada."(Auxiliar 4)

E diante do questionamento por parte da entrevistadora a respeito do relacionamento a que se referira, se era com a Secretaria de Saúde, responde afirmativamente e prossegue exemplificando: 
"Tinha, todo final de semana, tinha um auxiliar, um médico do CS lá, junto com o Secretário de Saúde. Cresceu muito, não é possível ser assim, mas eu acredito que deveria uma maior aproximação, de vez em quando, sei

lá, pra gente ter uma ligação maior, não ficar só no coordenador. A gente sente assim, muita coisa chega atrasada prar gente, a gente não tem conhecimento, uma informação que chega, às vezes nem vem e quando vem, por telefone. E o coordenador não está, não está sabendo também, vem por telefone e fica meio dificil a coisa, então fica difícil a coisa ser resolvida." (Auxiliar 4)

A vinculação das auxiliares ao projeto dos antigos Centros de Saúde, como comentamos anteriormente, era diversa. As reuniões a que se refere a profissional estão colocadas no trabalho de $S$ meke ${ }^{69}$ como fóruns de decisões e trocas. Certamente a rede ampliou-se, mas poderiam fazer parte do projeto da Secretaria de Saúde. Propiciar maior contato entre os trabalhadores, não só gerentes, como forma de propiciar a discussão de objetivos e políticas, e mesmo espaço de trocas, lamentavelmente perdido.

Parece interessante observar que a falta de espaço físico é mais gritante para aqueles que circulam no Serviço tais como docentes, coordenadores, enfermeiras e auxiliares. Para os médicos e dentistas, esse fato torna-se menos relevante, dado principalmente que os mesmos possuem espaços próprios para o exercício de suas atividades cotidianas, exceção comentada pela psiquiatra, pois na concepção do projeto original não eram previstas salas para 0 atendimento em Saúde Mental. 


\section{Auxiliares de Consultório Dentário}

Tal como as dentistas, inicialmente as auxiliares comentam o que é externo ao seu trabalho, ou seja: O Centro de Saúde tem deficiências de organização.

Ao discorrer sobre as deficiências do Serviço, a auxiliar (ACD) aponta que a recepção tem falhas, e que há falta de recursos materiais e de organização. Isolando mais uma vez a odontologia do resto do Serviço: "Iá fora".

Já a THD nos aponta como falhas a falta de médicos e auxiliares para cobrir todas as áreas:

"Falta de médicos ... Acho que deveria ter mais assim auxiliares pra estar podendo, sei lá porque quando falta, fica: (comentando as dificuldades cotidianas da escala) "Quem vai cobrir aqui, quem vai cobrir ali?" É muito, não tem uma outra (profissional) assim pra cobrir, mas não, no dia que vai, "Ah quem vai ficar, quem não vai ficar?" (comentando as queixas das que saem dos seus setores) Acho que falta um pouquinho de organização nesse aspecto." (THD)

A profissional informa sentir-se incomodada com a situação. Em nossa observação vemos que, às vezes, as auxiliares da área são chamadas para cobrir outros locais, do Serviço.

Uma delas $(A C D)$, comenta como deficiência do setor em que atua as decorrentes da alta demanda de clientes, o que resulta em lista de espera muito grande. Assim a preocupação dá-se com o: Atendimento da demanda para odontologia.

Essa preocupação da profissional com o número de clientes, presente pela primeira vez em nossa entrevista, deve ser ressaltada, por se basear na realidade 
da área, e também pelo fato de preocupar-se com as necessidades de Saúde da população usuária:

"Como odonto também tem falha, uma demanda muito grande... Nesses dias mesmo a gente sentou pra conversar sobre esse negócio de lista de espera, né? Eu não sei se isso é porque também tem uma demanda muito grande..." (ACD)

Prossegue falando sobre o fato de sentir-se externa ao Serviço e, portanto ter dificuldades em comentar o todo do CS:

"Agora assim, daqui pra fora, é que é tão difícil a gente ficar assim, né, eu tô mais lá dentro (a entrevista foi realizada em outra sala)

então não posso..."(ACD)

E referindo-se a algumas questões do Serviço:

"A gente tem, quando precisa de cirurgia...você tem que correr atrás de um... aparelhinho pra 'ver' pressão. Então, nesses dias mesmo... (criticando a falta de recursos) um aparelinho pro Centro de Saúde, toda a demanda. Então tem essa falhinhas que fica cansativo". (ACD)

Mais uma vez observamos que, para as auxiliares, sair do setor significa um desgaste. Cabe ainda esclarecer que há vários esfigmômetros no Serviço, e que no início de cada turno de trabalho os profissionais pedem o que necessitam à farmácia, que registra a saída como forma de controle... Provavelmente, no dia da cirurgia os instrumentos disponiveis estariam por todo o Serviço, em uso. 


\section{VII - Conclusões}

Durante o percurso de análise dos dados, de acordo com os eixos propostos, utilizamos um recurso para a compreensão das trajetórias e da própria formação, enquanto busca das origens dos profissionais e de sua inserção no Serviço. Ai encontramos diferentes modos de escolha da carreira pelos profissionais. No caso dos com nivel universitário, as escolhas foram baseadas em alguns critérios íntimos, relativos ao que percebiam como vocação, ou ainda, caso de uma das dentistas, como oportunidade de ascensão social. Decorrência natural, cursaram a Universidade com a finalidade de, posteriormente, engajar-se no trabalho.

Os de nivel médio tiveram uma escolha predominantemente determinada pela oportunidade de emprego. A maior capacitação deu-se pela necessidade de melhor qualificação, caso das auxiliares de Saúde e de consultório dentário, facilitada pela própria instituição, por meio dos Projetos de Formação em Larga Escala. É conveniente observarmos que a maioria das auxiliares de enfermagem sempre teve vínculo profissional com o Serviço, mesmo quando nos CS do Nóbrega ou do Garcia, e que duas delas (técnica 2 e auxiliar 3) ingressaram no Integração 
após trabalhar em serviço hospitalar. Destaca-se a técnica 1, antiga auxiliar, com uma experiência incipiente em instituição hospitalar como atendente.

Vimos ainda que alguns dos profissionais com curso superior, encontraram seu maior interesse pelo campo da Saúde Pública ainda na graduação e mesmo, caso das docentes de farmácia e terapia ocupacional, após ingresso na PUCCampinas. O campo, desde então, figurou para eles como a melhor alternativa de inserção profissional. Compreenderam esse espaço como de maior mobilidade diante dos outros oferecidos por meio do exercício, meramente técnico, das profissões escolhidas. Além disso entenderam o engajamento político e social representado pelo trabalho na área. Pudemos observar também, nos discursos, decorrência direta de sua maior capacitação serem os mais preparados para pensar um projeto político para o Serviço, face aos pressupostos do SUS e da Reforma Sanitária.

Posicionamento semelhante encontramos nas auxiliares de enfermagem, cabendo lembrar que o diferencial para a seleção das antigas auxiliares de saúde era o engajamento em trabalhos comunitários, o que durante a década de 70 , com o renascimento dos movimentos sociais, implicaria em maior consciência política e mesmo compromisso com as transformaçōes da sociedade. Também é interessante observar que uma destas auxiliares (auxiliar 1), a que apresentou dentre as do segmento o discurso, a nosso ver, mais empobrecido, não mencionou qualquer vínculo com atividades sociais, anterior ao ingresso. Devemos ainda levar em conta os propósitos do Projeto Larga Escala, pelo qual as auxiliares de saúde foram formadas auxiliares de enfermagem.

Os outros profissionais tiveram vínculos mais tardios com a área, e decorrentes muito mais da oportunidade de trabalho assalariado, que de uma opção 
pelo campo em questão. Temos também claro que o diferencial qualitativo do discurso e da inserção de alguns é fruto de sua busca por compreender as dimensões do campo da Saúde Pública, além do sentido político de seu trabalho.

Os docentes chegaram ao CS por contingências da Universidade e do Projeto Pedagógico, alguns com maior capacitação para o exercicio. Outros conheceram a área já no Serviço e, partindo dessa vivência tiveram seu aprendizado, buscando formas de inserir-se no modelo. É uma situação essa que, a nosso ver, acarreta as dificuldades observadas por alguns docentes acerca da qualidade de adesão do grupo, como um todo ao projeto. Mesmo aquelas citadas por outros e relativas às próprias dificuldades para realizar atividades de vigilância à Saúde. Entregando-se mais aos atendimentos individuais com vistas à reabilitação, caso de fisioterapia e a psicologia. Já fonoaudiologia, sendo o curso com ingresso mais recente, tem situação bastante peculiar, em que se aliam as faltas de conhecimento sobre o campo da saúde Pública com as de prática no Serviço, visto que a docente do curso supervisiona os alunos à distância.

Com relação ao ingresso dos médicos e dentistas na Secretaria de Saúde, subjaz às suas falas necessidade de um trabalho assalariado, conjuntural e, no caso das enfermeiras, uma pré-disposição a trabalhar fora do hospital, claramente explicitada pela enfermeira 2, bastante compreensivel se analisarmos que 0 trabalho nos CS ocorre em dias úteis e no periodo diurno. A opção pelo CS em si, tanto para médicos como enfermeiras, deu-se como decorrência do trabalho conjunto com a PUCCAMP, e pela maior qualificação do Serviço.

As formas de representar as finalidades do CS são exemplares com relação às diversas tendências contidas tanto no ideário da Reforma Sanitária, quanto num projeto para a sociedade. Ele se apresenta carregado de sentimentos de 
solidariedade humana, embora com tendência neoliberal, explicitamente ou não, de forma consciente ou não, caso dos profissionais para quem o Serviço presta-se a atender os carentes. Observamos ainda um falso argumento contido em um dos discursos dos médicos, pelo fato de o profissional propor diversas gradações de reembolso do usuário ao Sistema de Saúde. Nesse caso não existiria um Sistema Único, e o próprio caráter de acesso universal.

Cabe ainda esclarecermos que o pensar dicotomicamente prevenção-cura, presente nas falas de muitos profissionais, além de trazer insatisfação a eles, relativas às suas práticas, é originário de um projeto ideal de sociedade saudável, que nada tem a ver com o quadro nosológico brasileiro... Dificultando que os profissionais e o Serviço compreendam seu papel na prestação de Assistência Integral à Saúde das pessoas e das populações. De forma semelhante vemos a pretensão de normatização e regulamentação da demanda ao Serviço.

Com relaçāo ao modelo assistencial e ao cotidiano do Serviço identificamos, nas falas dos profissionais, dificuldades bastante evidentes. A primeira delas tem a ver com o fato de o CS não contar com recursos médicos suficientes para o atendimento da demanda em uma área de cobertura onde vivem cerca de 36.000 pessoas. Dessa forma, o acesso é bastante dificultado, o que se agrava quando não são eficazes as políticas públicas (sociais), relacionadas à prevenção das doenças e que possibilitem um estilo de vida mais saudável. Essas dificuldades estruturais refletem-se no Serviço de uma forma bastante crucial ou seja, todos os que ali trabalham, e têm mais ou menos consciência da origem do problema, sentem-se incomodados ao entrar em contato com fila, e até mesmo em encaminhar clientes para outros locais. 
O modelo também aqui é médico-cêntrico $e$, além disso, médicodependente, ficando claro para nós que os próprios usuários utilizam os serviços de outros profissionais, como psicólogos, nutricionistas e fisioterapeutas, de forma predominante em decorrência dos encaminhamentos médicos.

Muitos dos profissionais apontaram como deficiências do Serviço a dificuldade para a realização de ações de Vigilância à Saúde, limitadas neste contexto, com pouca disponibilidade para o transporte extramural e de visitação domiciliária. Diante de algumas dificuldades do Serviço, tão mencionadas pelos profissionais, como observadas por nós por ocasião da análise do modelo assistencial, é mister implementar medidas de prevenção primária que estão ao alcance, assim como melhorar as coberturas vacinais e de citologia oncótica, por exemplo. O que pode acontecer, talvez, como decorrência do próprio cotidiano dos profissionais.

Vimos pelas falas que há tentativas de melhora na atuação do Serviço, por meio dos trabalhos educativos, algumas delas de responsabilidade direta dos auxiliares, como o grupo de hipertensos, e outras realizadas pelas enfermeiras, dentistas, docentes e alunos.

Apesar das deficiências levantadas, tanto na avaliação dos usuários, como nas representações dos profissionais, o CS foi reconhecido como um Serviço legítimo, e de qualidade.

Um dos problemas identificados relacionava-se com a organização da recepção do CS que, por diversas razões, não possibilita um melhor atendimento da clientela, por não apresentar agilidade, principalmente no inicio do turno de trabalho (manhã) quando há maior movimento. Além disso, 
o fato de o agendamento das consultas estar determinado pela abertura das agendas, concentrada em um ou dois dias por mês, dificulta o ingresso e o acesso dos clientes que necessitem de um atendimento mais ágil, para o mesmo dia. Uma possivel alternativa de solução para o problema identificado seria flexibilizar $\circ$ agendamento, visando 0 acolhimento da demanda espontânea e, a partir dessa atitude de abertura, propiciar um seguimento com maior capacidade de resolução, e mais compatível com os recursos existentes e disponíveis no sistema local.

Outra falha da recepção, apontada por um dos médicos, sujeito em nosso estudo, é decorrente da dificuldade de alguns auxiliares para executar funções de triagem, as quais não Ihes cabem, e mesmo da inadequação do espaço físico da recepção que não propicia privacidade à clientela.

A inadequação da escala dos elementos da equipe de enfermagem, em rodízio pelas áreas, como foi dito por uma das profissionais de enfermagem de nível médio, agrava as deficiências do trabalho na recepção, que exige, um alto preparo técnico, contemplando as características de acolhimento, e muita paciência, principalmente diante das queixas da clientela não atendida, qualidades essas não comum a todos.

Ficou ainda evidente para nós que, consideradas as questões estruturais, há bastante espaço para a participação criativa no Serviço, decorrente sobretudo de uma disposição de ambos os coordenadores em abrir o CS à experimentação e estimular, principalmente, o trabalho nos grupos educativos e nas atividades de pesquisa.

Apesar de existir esse espaço, observamos que a ação cotidiana de alguns profissionais restringe-se ao consultar ou atender, o que acarreta, a 
nosso ver, uma leitura bastante parcial das finalidades do CS e que pode levá-los ao esgotamento em curto prazo. Assim ocorre com os médicos, que já entram no Serviço com uma única obrigação: consultar todos os dias e todo o tempo, sem possibilidades, dada a demanda e o modelo assistencial, e talvez suas próprias disponibilidades pessoais, de fazer qualquer outra coisa. Também aos dentistas vemos atribuída a obrigação, diária, de prestar atendimento individual aos clientes, executando atividades educativas dentro dos padrões de assistência às pessoas que conseguem vagas, ou em alguns eventos para a população (tais como a Feira da Saúde).

Dessa forma, o espaço de criação fica restrito aos coordenadores e docentes e à equipe de enfermagem e, principalmente, às enfermeiras, de quem se espera, no Serviço, muito pouco, aquém até do perfil de formação desse profissional. Isto é, espera-se que seu trabalho tenha um caráter técnico de supervisão junto à equipe e que sejam tratadas inúmeras questões também técnicas, envolvidas na prestação de assistência no campo da enfermagem

$\mathrm{Na}$ análise da fala do coordenador administrativo, identificamos a importância dada aos enfermeiros para a qualificação do Serviço, por meio de uma análise, segundo a qual profissionais da área não conhecem seu papel. Um dos motivos para essa situação pode ser devido ao fato de os profissionais de enfermagem terem sido absorvidos mais tardiamente pelos Centros de Saúde do municipio, quando já atuavam os médicos (afinados ao projeto) e os auxiliares de saúde. Com essa absorção pretendia-se maior qualificação nos serviços. Contradição agora expressa, o que se espera dos profissionais da área? Projetos (criatividade) que existiram pontualmente, ou 
que não se encontram de forma orgânica na Secretaria de Saúde e que, a nosso ver, transcendem a técnica e dão aos enfermeiros uma condição de interlocutores diretos com a população e uma capacıdade, inerente à maleabilidade do seu cotidiano, no qual, podem realizar supervisão direta na equipe, atividades de educação em serviço e mesmo assistência à população. E o que observamos no dia-a-dia são, parodiando nosso coordenador administrativo, os enfermeiros "bombeiros" preocupados, e às vezes tensos, com a resolução dos pequenos problemas cotidianos, extremamente absorventes e, sem tempo para pensar o próprio projeto profissional e, como conseqüência, implementá-lo. Curiosamente, o coordenador administrativo não expressou expectativas de projeto ou reconhecimento do papel dos outros profissionais.

Ao analisarmos as trajetórias aqui descritas e suas relações com a capacitação vimos que, os profissionais com formação e mesmo maior experiência na Saúde Pública têm maior mobilidade de pensamento e idéias sobre o Serviço, além de alternativas para intervenção mais efetiva.

Relacionando essa observação com o próprio trabalho das enfermeiras na Secretaria da Saúde vemos que, nos concursos, não é dada ênfase necessária à formação em Saúde Pública. Também não são sistemáticas as capacitações para o inicio das atividades na rede. Além disso, os profissionais que demonstram adesão maior ao projeto, e em alguns casos, maior qualificação são, em decorrência direta, alocados nos setores centrais e regionais responsáveis pelo planejamento e gestão do Sistema. Trata-se de uma divisão de trabalho que não avaliamos como a mais adequada. Também, dentro dos próprios serviços, esse tipo de profissional -o que não ocorre em 
nosso caso-é levado, como conseqüência natural, a assumir a coordenação, distanciando-se nessa função, ou por causa dela, da concepção das práticas de enfermagem e de sua execução.

Um outro aspecto problemático por nós detectado, foi a mudança do papel social dos antigos auxiliares de saúde, os quais, até o início da década de 80 , eram co-responsáveis pelo modelo, desde a concepção até a execução. Portanto, instados a ter um papel ativo, expresso por uma das nossas auxiliares de enfermagem (auxiliar 4) que recorda, a nosso ver muito justamente, a antiga atitude interessada da Secretaria da Saúde e o atual distanciamento.

Podemos ainda concluir que a falta de projeto, ou de conhecimento do papel dos enfermeiros, não seja exclusividade dos profissionais da área, mas decorrência da falta de projeto da Secretaria de Saúde para a rede como um todo, sem clareza de seus objetivos e missões. Ao tê-la, não os explicita. Assim, acreditamos faltar a definição de uma linha de trabalho que possibilite a todos os profissionais compreenderem o que deles se espera.

Variam também as representações das finalidades do CS, de acordo com as visões de mundo dos diversos profissionais, determinadas tanto pelas trajetórias nas quais, como supúnhamos inicialmente, a formação em Saúde Pública funciona como diferencial para sua conscientização e para a adesão ao projeto de Reforma Sanitária, em que cabe ao Serviço a prestação de assistência integral à Saúde.

Quando os profissionais falaram sobre o funcionamento do SUS vimos presentes diversas formas de análise da questão, variáveis de acordo com a ótica adotada, desde o SUS formal até o real, ocasião em que encontramos expressões 
compatíveis com o Projeto de Reforma Sanitária e outras influenciadas pela visão neoliberal.

Também o fato de profissionais, claramente favoráveis à implementação do SUS, caso de uma das docentes, acreditarem que o "SUS é uma utopia", não contribuem para uma luta pela consolidação do Sistema. Cabe esclarecermos que o tom de sua fala permitiu a compreensão do uso da palavra na acepção original do termo, ou seja: "Projeto irrealizável, Quimera, Fantasia" (Aurélio, Buarque de Holanda Ferreira). Será?

$\mathrm{Na}$ elaboração dessa representação (opinião) vemos uma premissa, a da dificuldade de se efetuarem transformações sociais, em nossa Sociedade, muitas vezes aceito por nós de forma pouco crítica, ou até criticamente, embora nos sintamos com poucas forças para colocar outro (projeto) em prática. 


\section{VIII - Considerações sobre o trabalho}

\section{desenvolvido}

Antes de finalizar o presente estudo, gostaria de estabelecer algumas considerações. A primeira é que ele só acaba neste momento, dadas as necessidades do programa de pós-graduação e as da "professora-pesquisadora", que parece ter chegado ao fim com tantas dúvidas quanto no início, durante a concepção desta criança que eu pretendia do coração, da mente, e agora vejo, também, do estômago.

Muitos dos momentos vividos durante a trajetória do trabalho foram de extrema angústia pessoal: Como eu sempre, tal como uma das nossas dentistas, tão interativa - so talkative - , consegui me manter tão quieta diante daquelas pessoas (entrevistadas)? E da angústia de querer dizer para elas que eu era feita da mesma massa? Fazia um trabalho que exigia distanciamento, mas muitas vezes queria mesmo é conversar, descobrir gente, e dizer o que sempre tenho pensado: A vida vale a pena não por ela mesma, mas pelas gentes, os universos inexplorados 
das mentes e dos afagos (ou pontapés, por quê não?), que representam os muitos, tantos, encontros humanos.

E aí, ao tentar finalizar este texto eu que, quando leio coisas anônimas, sempre tento descobrir se elas são escritas por homens ou por mulheres, percebo o quanto de feminino há nele. Faço questão de me colocar como a enfermeira sanitarista, que se aventurou pelo campo do interdisciplinar, tão característico da área e que, como os muitos professores componentes deste estudo, também um dia considerou-se out sider e resolveu militar (como esta palavra teve um significado forte para mim um dia), na ou pela Saúde Pública.

Agora, nesta etapa conclusiva, em que tanto quanto por ocasião do nascimento dos meus filhos, quando vivia muita dificuldade em expulsá-los para o mundo, me percebo vivendo angústia semelhante. O que fazer?

Voltando ao Serviço posso perceber, também, que ele está impregnado desse universo do feminino, seis homens e vinte e uma mulheres, dos quais omito nomes, e a quem sou imensamente grata. Importante descobrir o papel do feminino na construção das transformações sociais a partir de uma outra visão do mundo. ${ }^{13}$

Um universo desses de gentes (e de mulheres) tinha de ser peculiar, talvez cheio de acolhimento, uma das características enfatizadas enquanto qualidade da vivência do cotidiano no Serviço (o quê, na fala de uma das enfermeiras: "Às vezes é ruim"). Assim, o que aconteceu de bom, durante toda essa trajetória teve nome: equipe; profissionais. E o quê de ruim (deficiências), não teve nome, ou quase, sendo visto como decorrência da forma de organização, da estrutura, do modelo.

Também é incrivel perceber o quanto de tensão está presente entre o que a grande parte dos profissionais almeja e o que se vive. Essa contradição fica bastante evidente quando alguns são levados a concluir que dão o melhor de si, 
disso não tenho dúvidas, mas não se utilizam do Serviço e do SUS (nem os que Ihes são caros). Quando o fazem têm clareza, de que o uso é diverso do da população, o acesso é diferente. Além disso, alguns deles se sentem, por uma questão de coerência ideológica, compelidos a esse uso (solidário).

Que espécie de Universalização é essa? Do quê será que estamos falando? Quem é cidadão? Eqüidade, existe? Será possivel?

Apostando na utopia... eu acredito e desejo que sim.

Vejo-me agora compelida a questionar todo um projeto neoliberal que corroe as entranhas da sociedade brasileira e tem trazido repercussões imensas em nossa Universidade que, juntamente com o término deste trabalho, fragmentou parte do projeto da PUC para a Rede Básica, e relutou ainda, apesar dos nossos esforços, ao avaliar a qualidade pedagógica dele.

Faço questão de ressaltar as qualidades de luta dos da Universidade, demonstrada nesses muitos anos de vivência -em nosso caso- o do projeto da Saúde Pública. Destaco o esforço dos coordenadores dos Centros de Saúde e do Departamento de Medicina Social e Preventiva que, juntamente com todos os trabalhadores da Universidade envolvidos nos três Serviços (Ipaussurama, Balão do Laranja e Integração) despenderam mais de dois anos de grandes esforços pessoais e profissionais na tentativa de fazer sobreviver o projeto, quando poderiam ter limitado suas ações ao trabalho do cotidiano nos Serviços e mesmo à fria produção docente, destituída de compromisso com a Sociedade. Cabe agora questionar: "Que Universidade é essa?" e concluir, tristemente, já não mais na adolescência, que ".. o sonho acabou"..., ou não? Qual será nossa capacidade de resistência perto do final do século? Acordados?! Agora conseguiremos levar adiante um projeto de Sociedade mais justa?... O Projeto de Reforma Sanitária? 
Quero ainda ressaltar que um projeto de pesquisa deste porte não combina com o trabalho semi-solitário da autora e que deve ser compartilhado por parte dos da gênese do Serviço. Socializado, reinterpretado, revisto. Também, enquanto pesquisadora, vejo-me às voltas com algumas inquietações teóricas que exigiriam de mim muito mais tempo para, literalmente, me debruçar sobre os livros e aprofundar muitas das análises aqui contidas. Avalio, a priori, que houve, nesta trajetória, um doloroso crescimento, que poderia ter sido maior. Quando eu, professora da disciplina Trabalho de Conclusão de Curso, na Faculdade de Enfermagem tento, com meus alunos, avaliar, como digo e eles, processo e produto, vivo aqui a contradição de ater-me mais a esse produto do que ao próprio processo vivido.

Algumas das dúvidas que surgiram no transcorrer do trabalho são inerentes à complexidade da teoria das Representações Sociais e da pouca habilidade da pesquisadora em descobrir um caminho metodológico para lidar com elas. Outra questão constantemente presente foi compreender em que medida falávamos de Representações, e se elas eram representação do fenômeno (instituição) Centro de Saúde, ou dos olhares (opiniões) dos sujeitos sobre o objeto de sua atuação, o Serviço, chegando à conclusão de que trabalhamos aqui com as idéias e opiniões, e que estas são representativas dos vários modos de ver o CS estando, ao mesmo tempo, implicadas na configuração do modelo, sendo conseqüência deste. Isto é, podemos afirmar que, em nosso caso, houve íntima relação entre as palavras e as coisas. 


\section{IX -Referências Bibliográficas}

1 - ANDERSON, L.W. \& BURNS, R.B. Research in classrooms - the study of teachers, teaching and instruction. New York, Pergamon Press, 1989. [Cap. 3 Estudando salas de aula; traduzido por W.M. Rabello e adaptado por Martha R.P.Destro]. (mimeo)

2 - BAKHTIN, M. Marxismo e Filosofia da Linguagem. Problemas fundamentais do método sociológico na ciência da linguagem. São Paulo: HUCITEC, 1981.

3 - BERLINGUER, G. A doença. São Paulo: HUCITEC, 1988.

4 - BITTENCOURT, M. S. O Projeto de Formação de ACD e THD no município de Campinas. Oficina de Planejamento Estratégico Situacional em Saúde Bucal Coletiva- SMS, Campinas, 1996. (mimeo)

5 - BOLTANSKY, L. As classes sociais e o corpo. $3^{\mathrm{a}}$ ed., Rio de Janeiro: Graal, 1989 
6 - BRAGA, J.C.S. \& PAULA, S.G. de. Saúde e previdência: estudos de política social. São Paulo: CEBES/HUCITEC, 1985.

7 - BRITTO, L.P.L. Medicina e discurso. O relatório Pinotti e a doença de Tancredo. Campinas, São Paulo, Papirus, 1988.

8 - CAMPOS, G.W.S. A reforma da reforma: repensando a saúde. São Paulo, CEBES/HUCITEC, 1992.

9 - CAMPOS, G.W.S. A reforma sanitária necessária. In: Berlinguer G. et al. Reforma sanitária Itália e Brasil. São Paulo, CEBES/HUCITEC, 1988. p. $179-194$

10 - CAMPOS, G.W.S. Tréplica: o debate necessário à construção de uma teoria sobre a reforma sanitária. Saúde Deb. (23): 7-12, dez. 1988.

11- CAMPOS, G.W.S. A saúde pública e a defesa da vida. São Paulo, CEBES/ HUCITEC, 1991.

12 - CAMPOS, G.W.S. Modelos assistenciais e unidades básicas de saúde: elementos para debate. In: Nunes, E.D. Planejamento sem normas. $2^{a}$ ed. São Paulo: HUCITEC, 1994.p. 53-60

13 - CAPRA, F. O ponto de mutação. A ciência, a sociedade e a cultura emergente. $22^{a}$ ed. São Paulo: Cultrix, 1988 
14 - CONFERÉNCIA NACIONAL DE SAÚDE, $8^{\text {a }}$ Brasília, 1986. Anais. Brasilia, Centro de Documentação do Ministério da Saúde, 1987.

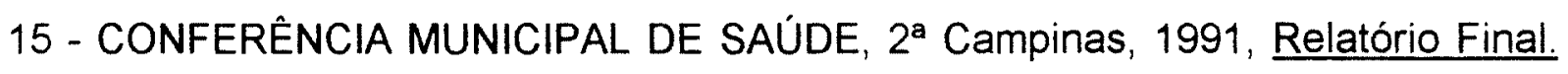
Campinas, Centro de Documentação da Secretaria de Saúde, 1991.

16 - CONTANDRIOPOULOUS, A.P. et al. Saber preparar uma pesquisa: definicão estrutura e financiamento. São Paulo, HUCITECIABRASCO, 1994.

17 - CONERTH, E. Questões fundamentais da hermenêutica. São Paulo: EPU, 1973

18 - CRUZ NETO, O.O. O trabalho de campo como descoberta e criação. In: Minayo, M.C. de S., org. Pesquisa social teoria, método e criatividade. $3^{a}$ ed. Rio de Janeiro: Vozes, 1994. p.51-66

19 - DALLARI. D. de A. Elementos da teoria geral do estado. São Paulo, Ática, 1985.

20 - DESTRO, M.R.P. Educação continuada: visão histórica e tentativa de conceitualizacão. $1^{\text {a }}$ ed. Campinas: CEDES/ Papirus, 1995. p 21-27

21 - DONÂNGELO, M.C.F. Medicina e sociedade: o médico e seu mercado de trabalho. São Paulo: Pioneira, 1975. 
22 - ELIAS, P.E.. Análises sobre a reforma sanitária e concepções políticas subjacentes: a visão autoritária do ideário progressista. Saúde Soc. 2 (1): $59-73,1993$.

23 - FARIA, J.E. Eficácia jurídica e violência simbólica: o direito como instrumento de transformação social. São Paulo: EDUSP, 1988.

24 - FARR, R.M. Representações sociais: a teoria e sua história. In Guareschi, P.\& Jovchelovitch, S.(orgs). Textos em Representacões Sociais. $2^{\mathrm{a}}$ ed. Petrópolis, Vozes, 1995.p.31-62

25 - FIALHO, R. B. Prontuário gerencial do centro de saúde Integração. Campinas, 1996. (mimeo)

26 - FOUCAULT, M. Microfísica do poder. $10^{\mathrm{a}}$ ed. Rio de Janeiro, Graal, 1973.

27 - FOUCAULT, M. O nascimento do clínica. Trad. Roberto Machado, $3^{\mathrm{a}}$ ed. Rio de Janeiro, Forense-Universitária, 1987.

28 - GARCIA, Ma. A A. O Ensino da Saúde Coletiva na PUCCAMP: a construção da história e seu repensar. Campinas, 1997.[Tese de Doutorado, Faculdade de Ciências Médicas da UNICAMP].

29 - GARRAFA. V. Desafios éticos na Política de Recursos humanos frente às necessidades de saúde. Brasília, Cadernos RH Saúde, 1(3): 1993. p.9-19 
30 - GERSHMAN, S. Sobre formulação de politicas sociais. In: Teixeira Fleury, S.M. Reforma sanitária, em busca de uma teoria. São Paulo, Rio de Janeiro: Cortez, ABRASCO, 1989. p $119-138$

31- GIMENES-MELLIN, A.S. Avaliação da capacidade resolutiva do CS Integração e do CS do Jardim Florence, no municipio de Campinas. São Paulo, 1992. [Dissertação de Mestrado - Faculdade de Saúde Pública da USP]

32 - GONÇALVES, R.B.M. Tecnologia e organização social das práticas de saúde: características do processo de trabalho na rede estadual de centros de saúde de São Paulo. São Paulo, 1986. [Tese de Doutorado. Faculdade de Medicina da USP].

33 - GOODE, W. J.\& HATT, P. K. Métodos em pesquisa social. $4^{\circ}$. ed. . São Paulo: Editora Nacional, 1972

34 - GUIMARÃES, A. L. Formação do profissional de enfermagem através do projeto larga escala: A experiência do municipio de Campinas. ॥ Encontro de Formação de Professores de Ensino Médio em Enfermagem - EERP-USP, Ribeirão Preto, 1989. (mimeo)

35 - JODELET, D. La representacion social: fenómenos, conceptos y teoria . In Moscovici, S.. Psicologia social: pensamiento y vida social, psicologia social \ problemas sociales. Buenos Aires, Paidós, 1986.p 469-493 
36 - KIRSCHBAUM, D, I. R. As práticas educativas para auxiliares de saúde na secretaria municipal de Campinas. Campinas, 1989. [Dissertação de Mestrado-Faculdade de Educação, UNICAMP]

37- L'ABBATE, S.. O direito à saúde: da reivindicação à realização. Projetos de política de saúde em Campinas. São Paulo, 1990. [Tese de DoutoradoFaculdade de Filosofia, Letras e Ciências Humanas da USP].

38- LANE, S. T. M. Linguagem, pensamento e representações sociais. In LANE S.T.M. \& Cado, W. (orgs) .Psicologia Social: o homem em movimento. São Paulo, Brasiliense, 1985. p32-39

39 - LUCKESI, C. et al. Fazer universidade: uma proposta metodológica. $6^{\mathrm{a}}$ ed. São Paulo, Cortez, 1991.

40 - LUZ, M.T. IX Conferência Nacional de Saúde: a VIII revisitada: avanços e impedimentos para implantação de uma nova política de Saúde. Saúde Deb. (37): 76-80, 1992.

41 - LUZ, M.T. Natural racional social: razão médica e racionalidade cientifica. Rio de Janeiro, Campus, 1988.

42 - MARTINS, Ma. T.C.T.L. Construção Coletiva da Prática Interdisciplinar no Centro de Saúde Integração; A experiência da. PUCCAMP, Campinas, 1996. [Dissertação de Mestrado em Educação da PUC- Campinas]. 
43 - MARTINS, Ma.T.C.T.L. \& MELLIN, A.S. Estudo do Modelo Assistencial de um Centro de Saúde Escola. V Congresso Brasileiro de Saúde Coletiva e V Congresso Paulista de Saúde Pública. Livro de Resumos. Águas de Lindóia, S.P., 367, 211, 1997.

44 - MERHY, E.E. A luta na saúde pela defesa da vida e algumas questões sobre o seu sujeito formulador: contribuições para o planejamento e a gestão dos serviços. Campinas, DMPS/FCM/UNICAMP, 1992

45 - MERHY, E.E. A mutilação da lei orgânica da saúde: vitória dos que desejam um povo mutilado. Saúde Deb., (30): 8-9, 1990

46 - MERHY, E.E. Brasil após 64: financiamento e modelos dos serviços de saúde. In: Nunes E.D., org, $2^{\mathrm{a} e d .}$ Planejamento sem normas. São Paulo HUCITEC, 1994.p 61-112

47 - MERHY, E.E. Em busca da qualidade dos serviços de saúde os serviços de porta aberta para a saúde e o modelo tecno assistencial em saúde. Defesa da vida. In Cecílio, Luiz Carlos de O (org.).Inventando a mudança na Saúde. São Paulo, HUCITEC, 1994.p117-160

48 - MERHY, E.E. O capitalismo e a saúde. Campinas, Papirus, 1988.

49 - MERHY, E.E. Planejamento ascendente: será que os municípios têm algo a dizer sobre isso para a montagem do SUS? Saúde Deb., (34): 42-7, 1993. 
50 - MINAYO M.C. S. O Conceito de representações sociais dentro da sociologia clássica. In: Guareschi, P. \& Jovchelovitch, S., orgs. Textos em representações sociais. 2 ed., Petrópolis, Vozes, 1995.p 89-112

51 - MINAYO, M.C. de S. O desafio do conhecimento: pesquisa qualitativa em saúde. $3^{\mathrm{a}}$ ed. São Paulo, HUCITEC/ ABRASCO, 1992.

52 - MINAYO, M.C.S. Técnica e arte: o desafio da pesquisa social. In: Minayo M.C. de $\mathrm{S}$, org. Pesquisa social: teoria, método e criatividade. $3^{\mathrm{a}}$ ed., Rio de Janeiro, Vozes, 1994.p 9-30

53 - MOSCOVICl, S. A representação Social da Psicanálise. Rio de Janeiro, Zahar, 1978.

54 - MOSCOVICI, S., org. Psicologia Social. Pensamento y vida social, psicologia social y problemas sociales. Buenos Aires, Paidós, 1986. 2 v.

55 - OFFE, C. Problemas estruturais do estado capitalista. Rio de Janeiro, Tempo Brasileiro, 1984.

56 - PAIM, J.N. As políticas de saúde e a conjuntura atual. Saúde em Deb., (15/16): $9-15,1984$.

57- PAIM, J.N. A reforma sanitária e os modelos assistenciais. In: Rouquairol M. Z. Epidemiologia \& Saúde. 4 ed. Rio de Janeiro, MEDSI: 1995. 
58 - PALNNER, R.E. Hermenêutica. Lisboa, Edições 70, 1969.

59 - QUEIROZ, M. I. Relatos orais: do "indizivel" ao "dizivel". Ciênc. Cult. 39: $272-$ 286,1986

60 - RESTITUTE, Ma. C. Sobre a coordenação acadêmica do Projeto Centro de Saúde Escola Integração. Campinas, PUCCAMP. s.d.

61 - RESTITUTE, Ma. C. A experiência do "Projeto Centro de Saúde Integração" Campinas, PUCCAMP, 1993.

62 - SÁ, C.P. de Representações Sociais: o conceito e o estado atual da teoria. In: Spink, M. J.. O Conhecimento no Cotidiano: As Representações Sociais na Perspectiva da Psicologia Social. São Paulo, Brasiliense, 1995. P19-45

63 - SADER, E. Quando novos personagens entram em cena. Experiências falas e lutas dos trabalhadores da grande São Paulo (1970 - 1980). $2^{\mathrm{a}}$ ed. Rio de Janeiro, Paz e Terra, 1988.

64 - SADER, E. \& GENTILI, P.A.A. Pós neoliberalismo: as políticas sociais e o estado democrático. $3^{\text {a }}$ ed. Rio de Janeiro: Paz e Terra, 1995.

65 -SANTOS, I. dos \& SOUZA, A. A. Formação de pessoal de nível médio pelas instituições de saúde: Projeto larga escala, uma experiência em construção. Saúde Deb $(24):$ 61-64, 1989. 
66 - SAVIANI, D. Escola e democracia. $27^{\mathrm{a}}$ ed. Campinas, Autores Associados, 1993.

67 - SCRAIBER, LILIA B. Pesquisa qualitativa em saúde: reflexões metodológicas do relato oral e produção de narrativas em estudo sobre a profissão médica. São Paulo, Rev. Saúde Pública, 29: 63-74, 1995.

68 - SIMIONI, A.M.C. \& ATIQUE, N.. Recursos humanos e municipalização: notas sobre o panorama legal. São Paulo, Saúde Soc., 2(1): 75-91, 1993.

69- SMECKE, E.D.M... Saúde e democracia experiência de gestão popular: um estudo de caso. Campinas, 1989. [Tese de Doutorado-Faculdade de Ciências Médicas da UNICAMP].

70 - SOUZA FILHO, E.A. de. Análise das representações Sociais. In Spink, M. J. 므 conhecimento no cotidiano: as representações sociais na perspectiva da psicologia social. São Paulo, Brasiliense, 1995.p 109-140

71 - SPINK, M.J. Desvendando as teorias implícitas: uma medodologia de análise das representações sociais. In: Guareschi, P. \& Jovchelovitch, S., orgs, Textos em representacões sociais. 2 ed., Petrópolis, Vozes, 1995.p 117-145

72 - SPINK, M.J.O estudo empirico das Representações Sociais. In: Spink, M.J. $\underline{\mathrm{O}}$ conhecimento no cotidiano: As representaçoes sociais na perspectiva da psicologia social. São Paulo, Brasiliense, 1995.p 85-108 
73- SUCUPIRA, A.C.L.S. Relações médico paciente na instituições de saúde brasileiras. São Paulo, 1981. [Dissertação de Mestrado-Faculdade de Medicina da USP].

74 - TANAKA, O.Y. et al. Análise do processo de planejamento e gerenciamento relatório final do projeto multicêntrico. São Paulo, ABRASCO, 1991.

75 - TANAKA, O.Y. et al. A municipalização dos serviços de saúde no Estado de São Paulo. Saúde Deb. (33): 73, 1991.

76 - TANAKA, O.Y. A porta de entrada do sistema unificado e descentralizado de saúde. Londrina, Saúde Deb.(28): 38, 1990.

77 - TANAKA, O.Y. Avaliação da qualidade de serviços básicos de saúde: o estudo do Distrito de Brasilândia. São Paulo, 1994. [Tese de Livre Docência-Faculdade de Saúde Pública da USP].

78 - TANAKA, O.Y. Avaliação da utilização dos serviços do posto de assistência médica e do pronto atendimento do Jardim São Jorge no Município de São Paulo. São Paulo, 1988. [Tese de Doutorado - Faculdade de Saúde Pública da USP).

79- TEIXEIRA FLEURY S. Reflexões teóricas sobre democracia e reforma sanitária. In: Teixeira Fleury S. org. Reforma sanitária, em busca de uma teoria. São Paulo, Cortez/ABRASCO, 1989. p 17-46 
80 - THOMPSON, P. A Voz Do Passado. História Oral. Rio de Janeiro, Paz e Terra, 1992.

81 - VALA, J. Sobre as Representações Sociais- Para uma Epistemologia do Senso Comum. Cad Ciênc Soc, Porto (4), abril, 5-30, 1986.

82 - WAGNER, W. Descrição, Explicação e Método na Pesquisa das Representações Sociais. In: Guareschi, P. \& Jovchelovitch, S., orgs,. Textos em representações sociais. 2 ed., Petrópolis, Vozes, 1995.p 149-186

83 - WESTPHAL, M.F. \& PELICIONE, M.C.F. Contribuição da educação em saúde para reforma sanitária. Londrina, Saúde Deb. (33): 68-72, 1991. 


\title{
X-Anexos
}

\author{
Anexo1
}

\section{Cursos, Departamentos e Disciplinas que participam do projeto Centro de Saúde Integração.}

Curso de Ciências Farmacêuticas (FCM- Faculdade de Ciências Médicas)

\section{Departamento de Farmácia}

Disciplina: Estágio Supervisionado em Farmácia (anual), no $4^{\circ}$ ano, carga horária total de 114 horas / aula, modulação $1: 2^{\star^{7}}$, supervisão de um docente com 10 horas semanais, nos outros períodos os alunos ficam sob supervisão indireta. $O$ curso também presta serviços ao CS por meio de seu Laboratório de Análises

\footnotetext{
${ }^{7}$ Modulação professor aluno significa número mínimo de alunos sob supervisão docente e é adotado pela Universidade como forma de pagamento das horas dos docentes, A carga horária da disciplina corresponde ao número de horas de cada aluno.
} 
Clínicas. No CS os alunos prestam assistência farmacêutica e têm atuação nos grupos de adultos.

\section{Faculdade de Enfermagem}

Departamento de Enfermagem de Saúde Pública e Mental.

Disciplina: Enfermagem de Saúde Pública, $4^{\circ}$ ano, carga horária de 180 horas, funciona com 3 docentes, modulação $1: 7$ e supervisão direta com 35 horas semanais. As propostas para o estágio destes alunos envolvem realização de assistência individual a mulheres, adultos e crianças, realização de atendimentos e visitas domiciliares, imunização e vigilância à saúde, atividades administrativas e de planejamento, e participação nos grupos.

\section{Curso de Fisioterapia (FCM)}

Disciplina: Prática Terapêutica Supervisionada (anual), com carga horária de 130 horas/aula, modulação 1:5, um docente em supervisão direta. Os alunos realizam assistência individual no Serviço e em domicílios.

\section{Curso de fonoaudiologia (Instituto de Psicologia)}

\section{Departamento de Distúrbios da Comunicação}

Disciplina: Fonoaudiologia 2: $3^{\circ}$ ano, carga horária de 90 hs de supervisão e 90 hs de aulas práticas (6 horas semanais), sob supervisão indireta, realizada fora do campo. Modulação 1:12, com 1 docente, disciplina anual. No Serviço cada grupo 
de alunos executa um projeto destinado exclusivamente à prevenção. Os projetos são elaborados de acordo com o objetivo dos alunos para atuação no serviço.

\section{Curso de Medicina (FCM)}

Departamento de Medicina Social e Preventiva

Disciplina: Programa Integrado de Saúde Coletiva - $5^{\circ}$ ano ( $1^{\circ}$ internato), com carga horária de 400 horas aula , 6 docentes, sob supervisão direta. Modulação 1:5. disciplina anual. Os alunos realizam assistência individual a adultos e idosos, atividades de vigilância à saúde e planejamento em saúde. Participam de alguns grupos.

\section{Curso de Nutrição (FCM)}

\section{Departamento de Nutrição}

Disciplina: Estágio Supervisionado em Saúde Pública, com carga horária de 120 horas/aula, modulação 1:4, supervisão direta em 10 horas semanais e indireta nos outros períodos de permanência dos alunos. Os alunos realizam atendimentos individuais, consultas conjuntas à crianças com os de enfermagem, e participam dos grupos. 


\section{Curso de Psicologia (Instituto de Psicologia)}

Departamento de Psicologia Clínica

Disciplina: Estágio Supervisionado em Psicologia Clínica, com carga horária de 240 horas de atendimento e 240 horas de supervisão (anual), alunos de $5^{\circ}$ ano, modulação 1:8 e supervisão direta do docente de 5 horas semanais. Estágio de aprimoramento (profissional) com supervisão direta 4 horas semanais: Realizam atendimentos individuais e em grupo terapêutico, e os de $5^{\circ}$ ano têm trabalho extramural em grupos e instituições da área de cobertura.

\section{Curso de Terapia Ocupacional (FCM)}

Departamento de Terapia Ocupacional

Disciplina: Prática Terapêutica Supervisionada, $4^{\circ}$ ano, carga horária de 240 horas (semestral), com 1 docente e modulação 1:2, supervisão de 16 horas semanais. Realizam atendimentos individuais, grupos terapêuticos, grupo da $3^{a}$ idade, trabalhos extra-murais e participam do grupo de hipertensos.

\section{Considerações sobre o projeto docente assistencial}

Restitute ${ }^{60,61}$ em avaliação do impacto do projeto da PUC no Serviço*, concluiu que este contribuiu para a diversificação do atendimento prestado à 
população da área, pelo caráter multiprofissional da equipe, bem como pela implementação de grupos de Educação em Saúde e formulação de novas práticas.

Quanto às propostas para atuação no Serviço vemos que todos realizam atendimentos individuais dentro de suas especificidades, exceto fonoaudiologia que propõe cursos e outras atividades, por meio de seus alunos desenvolve alguns projetos educativos destinados a grupos especificos e de curta duração. A maior parte dos cursos funciona, de forma integrada. Executando atividades de Educação em Saúde, trabalhos extra-muros e pesquisas operacionais. Os cursos de enfermagem e medicina realizam atividades de Planejamento em Saúde.

A coordenação acadêmica tem proposto e executado atividades conjuntas dentre as quais destacamos os Seminários, Visitas à Área de Cobertura e atividades de pesquisa. A seguir, estão expostos os objetivos das práticas acadêmicas no serviço, de acordo com o trabalho de Martins: ${ }^{42}$

\section{"Do Ensino:}

-Possibilitar a formação de profissionais com vivência em equipe multiprofissional.

-Proporcionar aos alunos o conhecimento do Perfil Epidemiológico populacional entendendo-o como recurso básico na elaboração de propostas de ações de Saúde.

-Reconhecer os agravos à Saúde da população, identificando a determinação do processo Saúde-Doença. 
- Conhecer a dinâmica de funcionamento e organização de uma Unidade Básica de Saúde, que integra o Sistema Municipal de Saúde.

\section{Da Assistência}

Contribuir para a melhoria da atenção à Saúde da população moradora na área de abrangência do serviço.

Contribuir para a construção de modelos de assistência que correspondam às necessidades de Saúde da população.

Prestar atenção integral à Saúde". 43 


\title{
Anexo 2
}

\author{
Caros (as) profissionais
}

Esta carta tem dois objetivos. 0 primeiro é comunicar que necessito da contribuição de alguns de vocês, selecionados por meio de sorteio, para colaborarem como entrevistados da pesquisa: "Os Profissionais de Saúde e as Representações Sociais das Finalidades e Práticas do Centro de Saúde Integração", tema de minha tese de doutoramento. O segundo objetivo é agradecer antecipadamente a sua participação e a característica de acolhimento e contribuição que sempre observo nas pessoas que trabalham neste Serviço de Saúde.

Atenciosamente, 


\section{Anexo 3}

\section{Roteiro para Entrevista}

Trajetória profissional.

Motivo porque trabalha no CS

Finalidades do Serviço.

Qualidades e deficiências do CS

Conhecimento do SUS opinião sobre seu funcionamento.

Serviço de Saúde utilizado em caso de necessidade pessoal ou familiar. 
O Paulinho, muito cansado da máe e do computador, disse que era fácil acabar a "tese", bastava escrever fim, disse também que the end servia.

Então,

\section{$\underline{\text { FIM, }}$}

\section{OU, COMO PREFERE O PAULO,}

\section{THE END.}

